\title{
Archeological Investigations and National Register Testing at 41CV163, Coryell County, Texas
}

John E. Dockall

Prewitt and Associates, Inc.

Jennifer K. McWilliams

Texas Historical Commission

Karl W. Kibler

Cross Timbers Geoarcheological Services

Follow this and additional works at: https://scholarworks.sfasu.edu/ita

Part of the American Material Culture Commons, Archaeological Anthropology Commons, Environmental Studies Commons, Other American Studies Commons, Other Arts and Humanities Commons, Other History of Art, Architecture, and Archaeology Commons, and the United States History Commons

Tell us how this article helped you.

This Article is brought to you for free and open access by the Center for Regional Heritage Research at SFA ScholarWorks. It has been accepted for inclusion in Index of Texas Archaeology: Open Access Gray Literature from the Lone Star State by an authorized editor of SFA ScholarWorks. For more information, please contact cdsscholarworks@sfasu.edu. 


\section{Archeological Investigations and National Register Testing at 41CV163, Coryell County, Texas}

\section{Creative Commons License}

\section{(c) (1) $\Theta(9$}

This work is licensed under a Creative Commons Attribution-NonCommercial-No Derivative Works 4.0 International License. 


\title{
ARCHEOLOGICAL INVESTIGATIONS AND NATIONAL REGISTER TESTING AT 41CV1636, CORYELL COUNTY, TEXAS
}

\author{
by \\ John E. Dockall \\ Jennifer K. McWilliams \\ and \\ Karl W. Kibler
}

Principal Investigator: Karl W. Kibler

REPORTS OF INVESTIGATIONS, NUMBER 151

Prewitt and Associates, Inc.

Cultural Resources Services

Austin, Texas

ARCHEOLOGICAL STUDIES PROGRAM, REPORT NO. 94

Texas Department of Transportation

Environmental Affairs Division

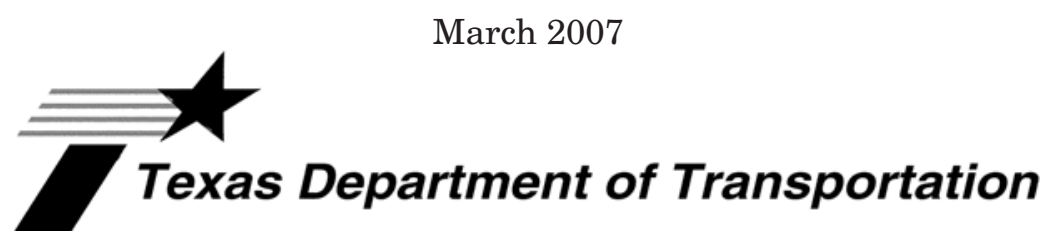

TEXAS ANTIQUITIES PERMIT NO. 3980 


\title{
ARCHEOLOGICAL INVESTIGATIONS AND NATIONAL REGISTER TESTING AT 41CV1636, CORYELL COUNTY, TEXAS
}

\author{
COPYRIGHT @ 2007
}

Texas Department of Transportation (TxDOT) and Prewitt and Associates, Inc. (PAI)

TxDOT and PAI jointly own all rights, title, and interest in and to all data and other information developed for this project under Contract 572XXSA006, Work Authorization 575305A006. Brief passages from this publication may be reproduced without permission provided that credit is given to TxDOT and PAI. Permission to reprint an entire chapter, section, figures or tables must be obtained in advance from the Supervisor of the Archeological Studies

Program, Environmental Affairs Division, Texas Department of Transportation, 125 East 11th Street, Austin, Texas, 78701.

\author{
jointly published by the \\ Texas Department of Transportation \\ Environmental Affairs Division \\ Archeological Studies Program \\ Lisa Hart, Director, Cultural Resources Management Section \\ Archeological Studies Program, Report No. 94 \\ Al McGraw, Series Editor
}

and

Prewitt and Associates, Inc.

Cultural Resources Services

Austin, Texas

PAI Project No. 206034

Reports of Investigations No. 151

Printed by Morgan Printing in Austin, Texas

ISBN 1-930788-48-7 


\section{TABLE OF CONTENTS}

ABSTRACT …

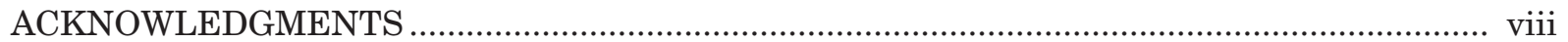

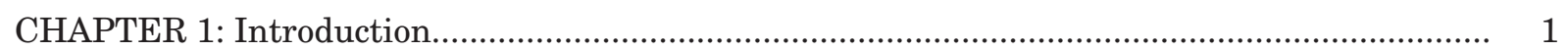

CHAPTER 2: Environmental and Archeological Background.................................................... 3

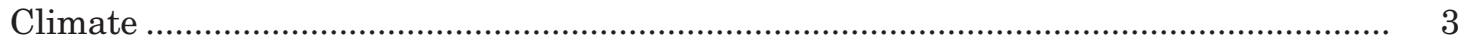

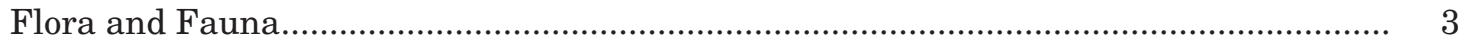

Previous Archeology in Coryell County ..................................................................... 4

Regional Cultural Chronology and Paleoenvironmental Reconstruction ........................ 5

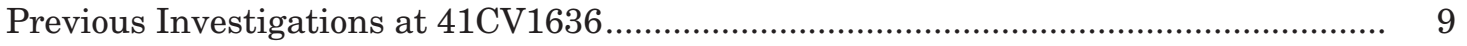

CHAPTER 3: Methods of Investigation and Work Accomplished ............................................. 11

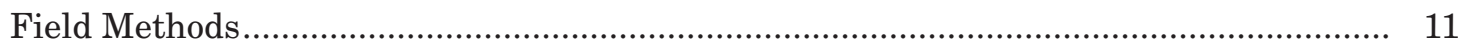

Laboratory Methods............................................................................................ 13

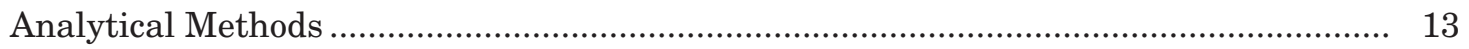

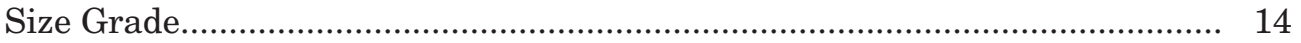

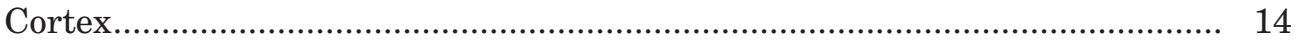

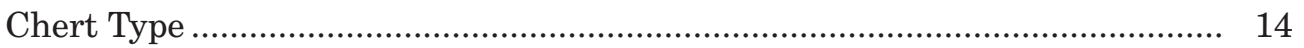

Flake Type ............................................................................ 15

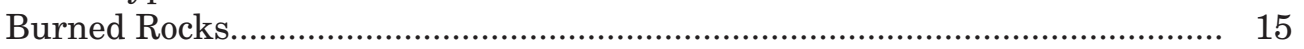

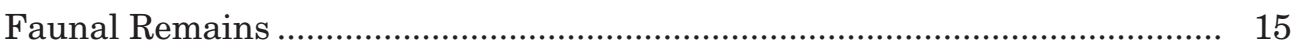

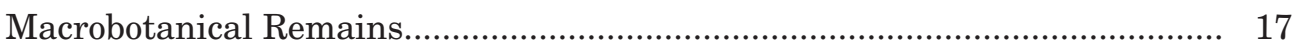

CHAPTER 4: Site Stratigraphy and Definition of Analysis Units ............................................ 19

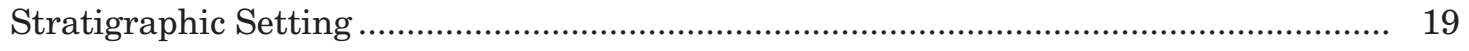

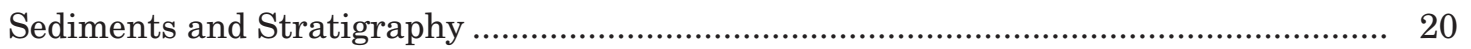

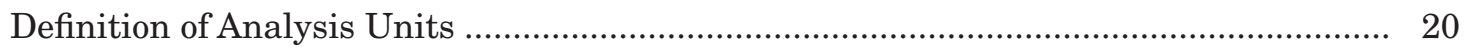

CHAPTER 5: Results of Investigations: Analysis of Features and

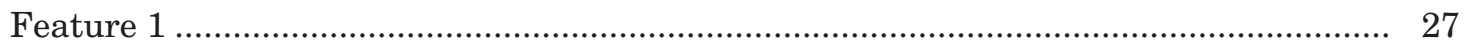

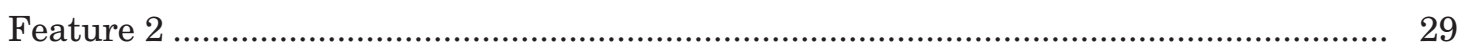

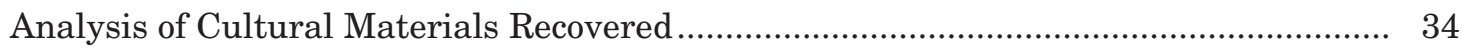

Chipped Stone Artifacts ............................................................................. 34

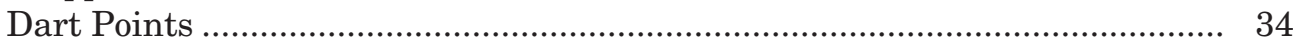

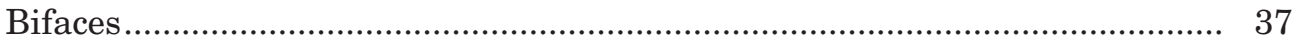

Edge-Modified Flakes.......................................................................... 38

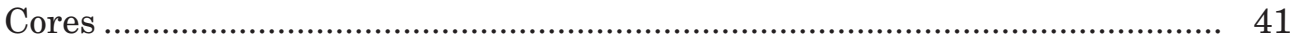

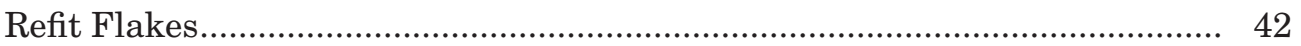

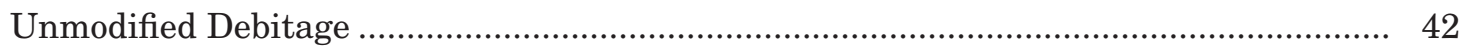

Raw Material Types ............................................................................ 42

Raw Material Catchment....................................................................... 44

Unmodified Debitage Patterns ............................................................... 44

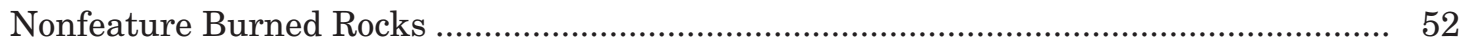

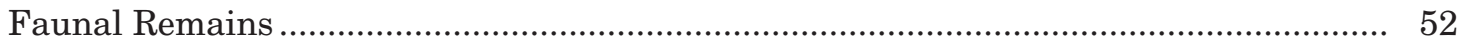

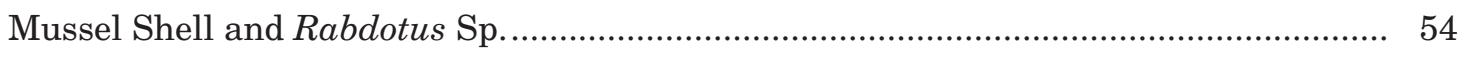

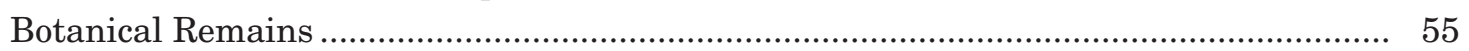




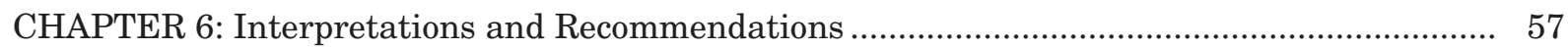

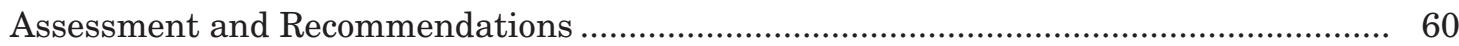

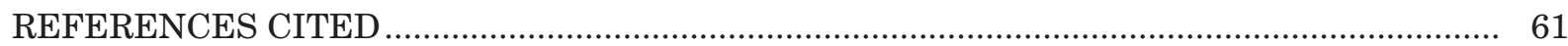

APPENDIX: Provenience Data for Artifacts Recovered ........................................................ 67 


\section{LIST OF FIGURES}

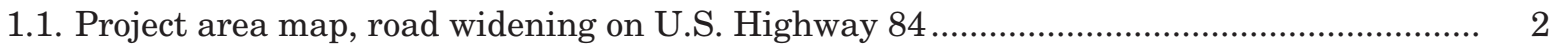

2.1. Prehistoric cultural sequences of Prewitt, Johnson and Goode, and Collins .................... 6

3.1. Map of the project area showing location of 41CV1636 ............................................... 12

4.1. Stratigraphic profile of Test Unit 2, east wall .............................................................. 21

4.2. Stratigraphic profile of Test Unit 1, south wall .............................................................. 22

4.3. Composite stratigraphic profile of Test Unit 3, north and east walls ............................... 23

4.4. Stratigraphic profile of Test Unit 4, east wall .................................................................. 24

4.5. Line graph showing peaks in abundance of unmodified debitage and burned

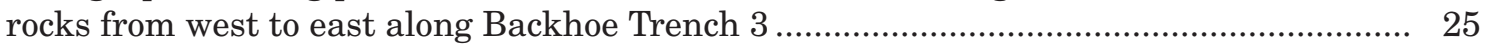

5.1. Limestone slab fragments line the base of Feature 1, a concentration of burned rocks .... 30

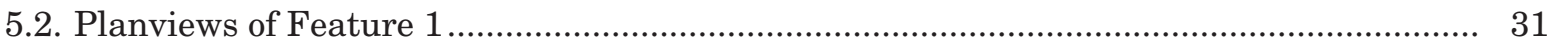

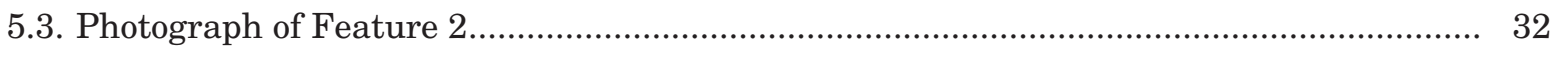

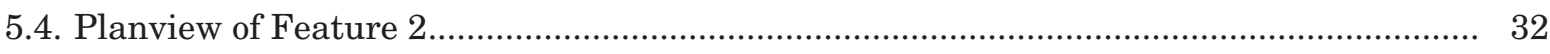

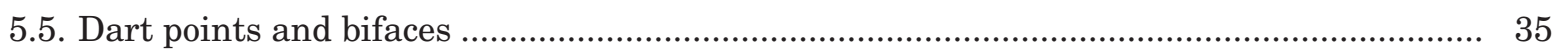

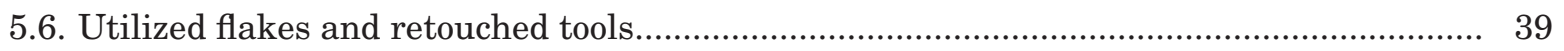

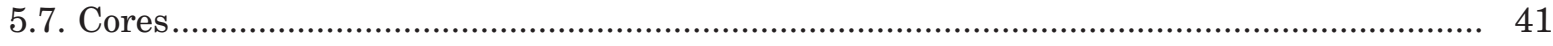

5.8. Refit small blade-like flake and larger flake .................................................................. 42

5.9. The $20-\mathrm{km}$ radius around $41 \mathrm{CV} 1636$ shows potential sources of lithic raw material........ 45

5.10. Distribution curves for chert types and size grade ..................................................... 50

5.11. Size class distribution curves for various flake types ................................................. 52 


\section{LIST OF TABLES}

3.1. Fort Hood chert types grouped according to bedrock and alluvial gravel sources. 15

3.2. Flake types and critical technological attributes.

5.1. Total counts and densities of artifacts and other material recovered from 41CV1636...... 28

5.2. Total counts and weights of artifacts recovered from flotation samples............................ 29

5.3. Summary of burned rocks and other materials from Feature 1 ..................................... 32

5.4. Summary of burned rocks and other materials from Feature 2 ...................................... 34

5.5. Dimensions of edge-modified flakes recovered from 41CV1636 ...................................... 39

5.6. Experimental debitage data sets for comparison with 41CV1636 ..................................... 48

5.7. Proportion of different chert types at 41CV1636 .......................................................... 49

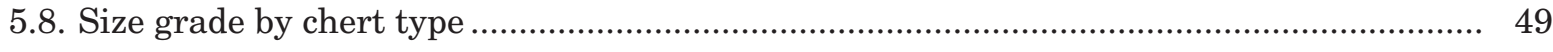

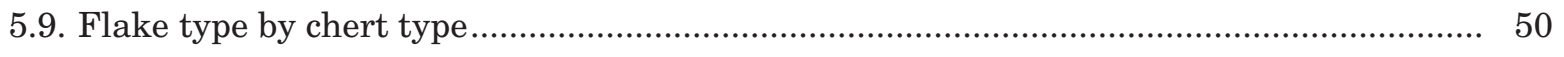

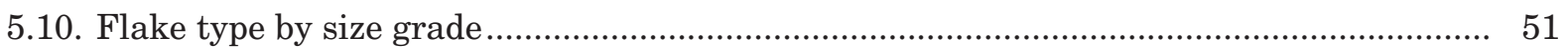

5.11. Summary of faunal remains from 41CV1636 .............................................................. 53

5.12. Summary of recovered mussel shell umbos and hinge teeth recovered

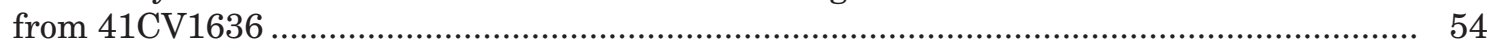

A.1. Provenience of artifacts recovered by excavation unit and level .................................... 69 


\begin{abstract}
Prewitt and Associates, Inc. (PAI), conducted archeological testing of 41CV1636 for the Texas Department of Transportation (TxDOT), Environmental Affairs Division, under Contract No. 575XXSA006 (Work Authorization No. 57530SA006) and Texas Antiquities Permit No. 3980 from the Texas Historical Commission. Site 41CV1636 is situated in northwestern Coryell County, approximately $13 \mathrm{~km}$ east of Evant, Texas. The site was located during an archeological survey for a proposed roadway widening project along U.S. Highway 84. Proposed design plans required an additional $5 \mathrm{~m}$ of new right of way that would directly impact 41CV1636. Site 41CV1636 is a prehistoric site buried in Holocene alluvium of a relict channel of Cowhouse Creek. At this location, Cowhouse Creek has a ca. 1.5-km-wide stretch of Holocene alluvium. Archeological testing consisted of the excavation of two backhoe trenches and four 1x1-m hand-dug units. All sediments were water-screened. Excavations recovered a rather large lithic assemblage and two burned rock features: a partially dismantled slab-lined, basin-shaped hearth and a possible burned rock discard pile or stockpile. The recovery of Pedernales and Provisional Type 1 projectile point forms argues for a multicomponent occupation during portions of the early Late Archaic Period; however, only one analysis unit could be defined. The alluvial deposits at 41CV1636 appear correlative to the Fort Hood and West Range alluvium identified by other researchers along downstream portions of Cowhouse Creek on the Fort Hood military reservation. Soil stratigraphy at the site indicates that cultural occupations occurred as floodplain aggradation slowed and soil development began. Sedimentation via overbank flooding and colluvial deposition continued at a pace quick enough to impose some vertical separation between multiple occupations that occurred during a short time span. Poor preservation of organic remains has been a hindrance to providing good temporal control at the site. The lack of radiocarbon ages and poor preservation mean that few substantial statements can be made regarding chronology or subsistence. 41CV1636 is considered ineligible for the National Register of Historic Places or as a designated State Archeological Landmark, and no further work is warranted for this site.
\end{abstract}




\section{ACKNOWLEDGMENTS}

This project was initiated and carried out by the Environmental Affairs Division of the Texas Department of Transportation (TxDOT). TxDOT personnel of the Waco District, supervised by David Jayroe, were of invaluable assistance. They provided backhoe expertise and also excavated the sump used to hold water for our water-screening operations. The Waco District also provided a tank truck to deliver water to fill the sump and helped us backfill trenches and excavation units. David also took extra time to erect a silt fence barrier around the sump and associated backdirt. The assistance and goodwill provided by David and his staff was much appreciated on this and numerous previous projects.

Karl Kibler was the project's principal investigator, and Jenny McWilliams was the project archeologist. Karl also served as the project geoarcheologist and provided soil descriptions for each of our backhoe trenches. The field crew consisted of Tim Griffith, Mark Holderby, Weldon "Tripper" Hammond, Rob Thrift, and John Dockall. Jenny McWilliams also served as site photographer and capably coordinated field records and field laboratory and processing tasks without a hitch. The ominous task of water screening during January on the Lampasas Cut Plain fell to Weldon Hammond, who carried out the task with humor and style-especially after the water-screening buckets full of water, baking soda, and soil froze over on a particularly cold night. Tim Griffith assisted Mr. Hammond in water screening to keep apace of excavation. Between them, several hose problems were resolved that allowed us to keep on schedule. The efforts of the field crew resulted in a wellexecuted and smoothly run field project.

Laboratory processing, sorting, and labeling was accomplished by Rob Thrift and was supervised by Karen Gardner. Ms. Gardner also provided mussel shell identifications and taphonomic information. Tim Griffith identified the faunal remains. Gemma Mehalchick provided advice on Fort Hood cherts. Lithic analysis was conducted by John Dockall, the principal author. The report was compiled and portions written by the principal author, but it also drew from the interim report prepared after the fieldwork was completed (McWilliams and Kibler 2006). Karl Kleinbach, senior archeologist with the Cultural Resources Management Program at Fort Hood, graciously provided a copy of the Fort Hood chert type collection and descriptions on CD for comparison to our recovered lithic sample. Mr. Johnny Arnold is acknowledged for providing gate access into his pasture and enabling us to complete our fieldwork.

Report preparation and production would not have succeeded without the efforts of Sandy Hannum and Brian Wootan as cartographers and graphics specialists. Elaine Robbins edited and produced the report. 




\section{INTRODUCTION}

Prewitt and Associates, Inc. (PAI), conducted archaeological testing of 41CV1636 for the Texas Department of Transportation's (TxDOT) Environmental Affairs Division, under Contract No. 575XXSA006 (Work Authorization No. 5730SA006) and Texas Antiquities Permit No. 3980 from the Texas Historical Commission. Fieldwork was initiated on January 9, 2006, and concluded January 13, 2006. Laboratory processing and interim report preparation took place during January and February 2006. The work was done to assist TxDOT in compliance with Section 106 of the National Historic Preservation Act and the Antiquities Code of Texas. A portion of the site extends into proposed new right of way needed for the widening of U.S. Highway 84 along the Cowhouse Creek floodplain in Coryell County. Archeological investigations were restricted to the part of the site within the proposed new right of way.
Site 41CV1636 is in northwestern Coryell County, approximately $13 \mathrm{~km}$ east of Evant, Texas (Figure 1.1). The site is situated on the southeastern edge of a relict channel of Cowhouse Creek at an elevation of ca. $960 \mathrm{ft}(292.60 \mathrm{~m})$ above sea level. The site lies in a long, narrow pasture that also functions as a wet-weather slough. Initial investigations were prompted by the proposed widening of U.S. Highway 84, which, with the acquisition of ca. $5 \mathrm{~m}$ of new right of way, would directly affect 41CV1636. At this location, Cowhouse Creek has a ca. $1.5-\mathrm{km}$-wide band of Holocene alluvium mapped (Bureau of Economic Geology 1970, 1976). Site 41CV1636 is a prehistoric site buried within this alluvium and minor amounts of colluvium. Archeological testing consisted of excavating two backhoe trenches and four $1 \mathrm{x} 1-\mathrm{m}$ hand-dug units. An extensive artifact assemblage was recovered from the subsurface testing, and two cultural features were identified. 


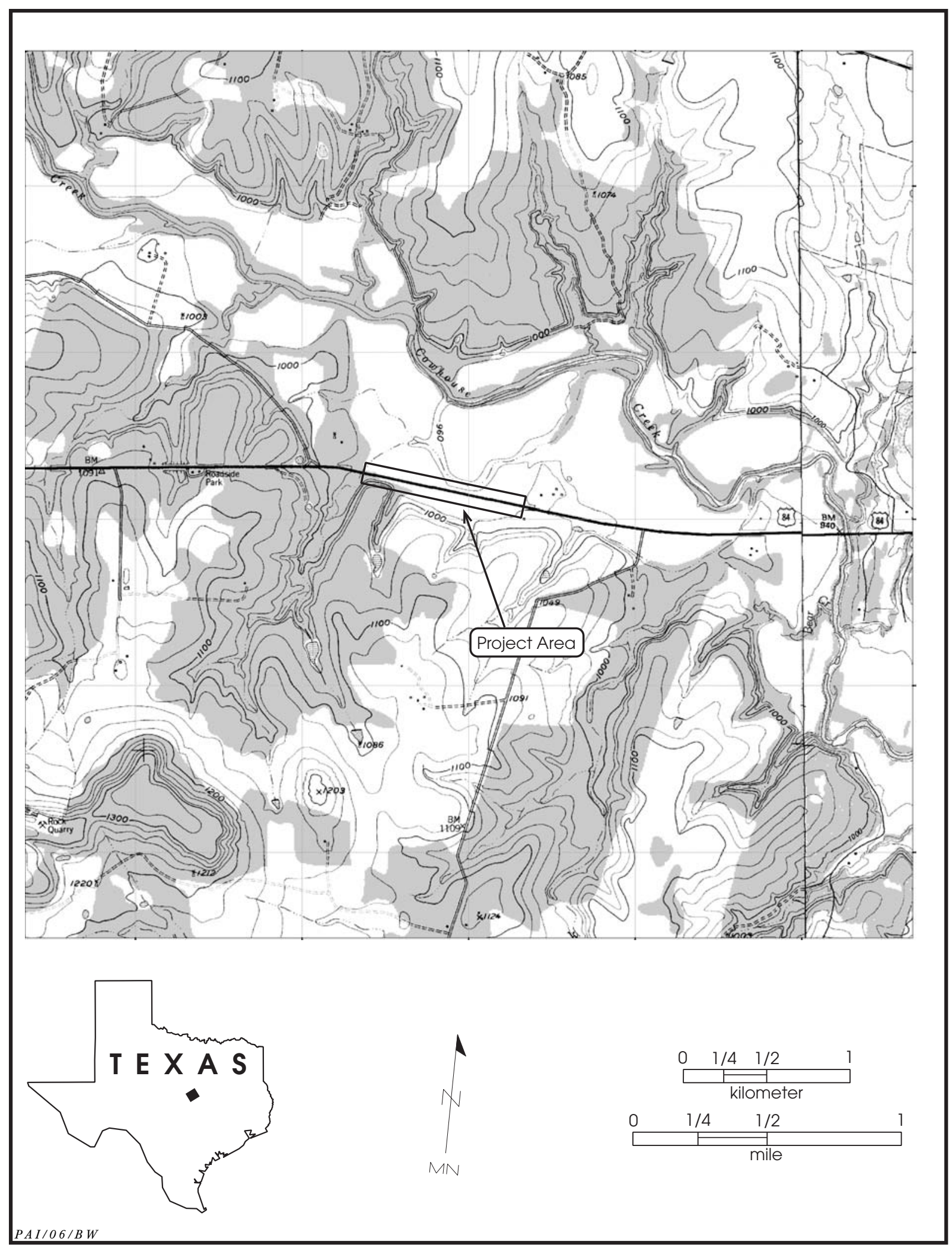

Figure 1.1.Project area map, road widening on U.S. Highway 84. Section of USGS 7.5-minute quadrangle, Pearl, Texas. 


\section{ENVIRONMENTAL AND ARCHEOLOGICAL BACKGROUND}

Coryell County is situated within the Lampasas Cut Plain, a subprovince of the Grand Prairie (Hayward et al. 1996) and dissected northeastern edge of the Edwards Plateau (Arnn et al 2000:5; Hill 1901; Nordt 1992:1). The Lampasas Cut Plain is dominated by a mesa topography consisting of broad lowland areas between upland mesas capped by the more erosionresistant rocks of the Edwards Formation (Hill 1901:77-78). According to Fenneman (1938:106), the western edge of the Lampasas Cut Plain is 1,500 to $1,800 \mathrm{ft}$ above mean sea level and 300 to $400 \mathrm{ft}$ higher than the valleys along the edge of the escarpment. This area also represents a zone of transition between more humid climates to the east and semiarid climates farther west. The environmental and topographic gradients are steep enough to impart distinctive landscape and vegetation changes along an east to west direction. This portion of Coryell County is situated west of the Balcones Fault Zone on Lower Cretaceous carbonate rocks.

\section{CLIMATE}

The modern climate of the Coryell County area is typically subtropical, with hot, humid summers and fairly short, dry winters (Natural Fibers Information Center 1987:6). Prevailing winds are from the south and reach peak strength in the spring. The area has high summer temperatures, with an average of $83^{\circ} \mathrm{F}$ $\left(28.3^{\circ} \mathrm{C}\right)$ and an average daily maximum of $96^{\circ} \mathrm{F}\left(35.5^{\circ} \mathrm{C}\right)$ in Coryell County. Average winter temperature is $49^{\circ} \mathrm{F}\left(9.4^{\circ} \mathrm{C}\right)$ but can vary considerably during periodic passing cold fronts, fostering a temperature pattern of alternating cold and mild periods (Arnn et al. 2000:5; Mc-
Caleb 1985:3).

Annual precipitation averages 32.5 inches $(82.6 \mathrm{~cm})$ for Coryell County (Natural Fibers Information Center 1987:121). Rainfall can occur year-round, with peak rainfall amounts occurring in late spring and early fall.

\section{FLORA AND FAUNA}

Coryell County falls almost entirely in Blair's (1950)Balconian biotic provinces.Asmall portion of northern Coryell County is in the Texan biotic province, wherethefloraandfaunaareaninterestingmix of speciesadaptedtotheBlacklandPrairiestotheeast and the Edwards Plateau to the west.

Tharp (1939) included three distinct vegetation patterns within the Balconian province (Blair 1950:113). These consist of oak-hickory in the vicinity of the Llano Uplift, an oak-cedar region in the southern and eastern portions of the Edwards Plateau, and a live oak-mesquite savanna region in the central and eastern portions of the Balconian province. According to Tharp (1939:14), the oak-cedar region of the Edwards Plateau encompasses the Lampasas Cut Plain as defined by Hill (1901).

Riskind and Diamond (1986:29) consider the Lampasas Cut Plain part of the greater Edwards Plateau natural region, with a mix of plant and animal species typically found in the Balconian and Texan biotic provinces. The topography of the Cut Plain provides the region with characteristics of an open grassland or woodland. The authors also note the presence of plant communities characteristic of regions farther north, such as the post oak-blackjack oak woodlands. Grasslands north and east of the Cut Plain are extensions of True Prairie and include 
such species as little bluestem, Indiangrass, big bluestem, silver bluestem, wintergrass, dropseed, and sideoats grama. Mesquite and ashe juniper are also present but not as common as in the uplands of the Balcones canyonlands.

There are 57 mammal species included in the Balconian faunal assemblage, but none are restricted to this province (Blair 1950:113). Eight species are also present in the Texan province and various riparian zones (Blair 1950:101). Additional fauna includes 36 snake species, 15 toad and frog species, and 16 lizard species. Pronghorn antelope, bison, and other economically important species were present during the prehistoric periods but were killed off in historic times.

\section{PREVIOUS ARCHEOLOGY IN CORYELL COUNTY}

The earliest documented formal excavations in Coryell County were apparently conducted at Ranney Creek Cave (41CV14) in the early 1930s by H. Ramseur but have never been published (Cliff 2002:17; Prewitt 1974: Table 4). Based on information from Texas Archeological Research Laboratory county files, Prewitt summarized that the site yielded the remains of at least 12 individuals removed during controlled excavations with an additional unknown number removed by pothunters. Skeletons were flexed and were associated with mussel shells, manos, and metates but no temporal diagnostics (Prewitt 1974: Table 4).

Robert Stephenson conducted a preliminary survey for Belton Reservoir in the late 1940s and included a small area of Coryell County on the upper end of the reservoir footprint (Shafer et al. 1964). Survey and later test excavations were conducted in middens and rockshelter sites along Belton Reservoir by E. H. Moorman and E. O. Miller (Miller and Jelks 1952). Their work consisted of excavations and testing at GrimesHouy Shelter, the Urbankte site, Grimes-Houy burned rock midden, the Johnson Hole site, and the Horse Creek burned rock midden.

Shafer and others conducted more testing at Belton Reservoir and tested 12 sites (Shafer et al. 1964). A total of 34 archeological sites were visited during the 1962 field season, but only 2 of these were located in Coryell County: 41CV18, the Squawtown site; and 41CV19. Both sites yielded limited archeological assemblages in mixed terrace deposits along the Leon River.

In 1964 in northeastern Coryell County and southwestern Bosque County, Hog Creek Reservoir was the locus of site testing and mitigation (Henry et al. 1980). At the end of fieldwork, 29 sites had been recorded within the Hog Creek study area, but only 9 were further investigated by testing and data recovery. Four of these sites were located in Coryell County: 41CV69, 41CV69A, 41CV61, and 41CV62.

The majority of archeology that has been conducted in Coryell County has been under the auspices of extensive programs of survey, monitoring, and resource management at Fort Hood. Recent discussion and summaries of work conducted at Fort Hood can be found in Ellis et al. (1994) and Abbott and Trierweiler (1995).

Several of these projects have focused on or included portions of the Cowhouse Creek drainage basin and provide a glimpse of land use along the creek. A series of sites along the western end of Cowhouse Creek as it flows onto Fort Hood property was investigated as part of a larger program of National Register of Historic Places (National Register) eligibility testing (Abbott and Trierweiler 1995). The West Cowhouse Group consisted of nine sites in Coryell County located on Pleistocene and Holocene terraces. The site group (41CV1097, 41CV1098, 41CV1099, 41CV960, 41CV1105, 41CV1038, 41CV97, 41CV95, and 41CV1200) included large and deeply stratified sites located on and within the principal Holocene stratigraphic units as previously defined by Nordt (1992). Along this portion of the creek on Fort Hood, chert availability is strictly limited to the channel, and no cherts outcrop in the surrounding uplands (Trierweiler 1995:23-24). Results of debitage analyses from these sites provide some interesting trends that may have implications for sites like 41CV1636 located along Cowhouse Creek farther to the west, beyond Fort Hood (Abbott and Tomka 1995:692-698). Chert types indicate that both upland and alluvial sources were used. In the sample, North Fort (49 percent) and Southeast Range (36 percent) cherts were most abundant, while cherts from within the Cowhouse Creek drainage represented only 13 percent. West Fort cherts comprised only 1.5 percent. Contrary to what may be expected, the majority of cherts were identified as types from more distant sources (up to $25 \mathrm{~km}$ ) rather than coming from adjacent channel gravel or 
terrace sources. Cortex, present on 15 percent of identified flakes, is largely stream abraded, indicating that much of the primary reduction material was obtained from local sources.

There has been limited professional archeological work conducted in the immediate region surrounding 41CV1636, and there are no archeological sites within or adjacent to the project area. The most significant project in the vicinity included sections of the Northern Alternative Route for the All American Pipeline project sponsored by the Bureau of Land Management in portions of Hamilton and Coryell Counties (Turpin et al. 1992) to the north of the current project area.

Recently, archeologists from PBS\&J conducted National Register eligibility testing at 41CV1630 (Cliff 2002). The site, located along State Highway 36 in Coryell County near the city of Gatesville, was previously identified as an unrecorded historic property (Holmes 2001). Situated north of the Leon River on one or more terraces and the current floodplain, it is a multicomponent occupation dating to the middle portion of the Late Archaic period (ca. 2650-2050 B.C.) and the middle part of the Late Archaic period (ca. A.D. 200-550). Site 41CV1630 also had two burned rock features and probably functioned as a small campsite, similar to 41CV1636.

\section{REGIONAL CULTURAL CHRONOLOGY AND PALEOENVIRONMENTAL RECONSTRUCTION}

The following discussion on regional cultural chronology is adapted from Kibler and Boyd (1999). The prehistoric cultural sequence for centralTexas can be divided into three broad periods: Paleoindian, Archaic, and Late Prehistoric, although the terms Neoarchaic (Prewitt 1981, 1985) and Post-Archaic (Johnson and Goode 1994) have been used at times in place of the Late Prehistoric. Prewitt's (1981, 1985) cultural-historical framework incorporating discrete temporal and technological units (i.e., phases) has generally been replaced by revised chronologies proposed by Johnson and Goode (1994) and Collins (1995). The most recent revision by Collins (1995) does not use the term "phase" to describe cultural-historical units; instead, it names intervals or patterns based on diagnostic projectile point styles and associated radiocarbon assays (e.g., Martindale-Uvalde interval of the Early Archaic period) within each period or subperiod. The cultural chronology proposed by Collins (1995) is preferred and is the most precise in terms of dating projectile point styles (Figure 2.1). It is used throughout this report.

The Paleoindian period (11,500-8800 B.P.) represents the earliest known cultural manifestation in North America. Sites and isolated artifacts from this period are fairly common across central Texas. The period is often described as having been characterized by small but highly mobile bands of foragers who were specialized hunters of Pleistocene megafauna. A more accurate view of Paleoindian lifeways includes the utilization of a much wider array of subsistence resources. Recent investigations at the Wilson-Leonard site (41WM235) support this view and have challenged the fundamental defining criteria of the Paleoindian period, that of artifacts in association with late Pleistocene megafauna (Masson and Collins 1995). Environmental conditions during the Paleoindian period were quite different than today, presenting the early inhabitants with a different array of resources. Nordt et al. (1994) view this period as a transition between cooler, moister late Pleistocene conditions and warmer, drier Holocene conditions. They estimate that warm season, or C4, grasses steadily increased in abundance throughout this period. Toomey et al. (1993) also see this time as a period of transition, with summer temperatures increasing rapidly but still $2-3^{\circ} \mathrm{C}$ below modern values. Toomey et al. (1993) suggest that a decrease in effective moisture beginning around 14,000 B.P. intensified and culminated ca. 10,500 B.P.

Collins (1995) divides the Paleoindian period into early and late subperiods. The early subperiod consists of two projectile point style intervals: Clovis and Folsom. It is notable that while the evidence for pre-Clovis human occupations in North and South America is mounting, there is as yet no credible evidence for occupations earlier than Clovis in central Texas. Clovis chipped stone artifact assemblages, including the diagnostic fluted lanceolate Clovis point, were produced by bifacial, flake, and prismatic-blade techniques on high quality and often exotic lithic materials (Collins 1990). Along with chipped stone artifacts, Clovis assemblages include engraved stones, bone and ivory points, stone 


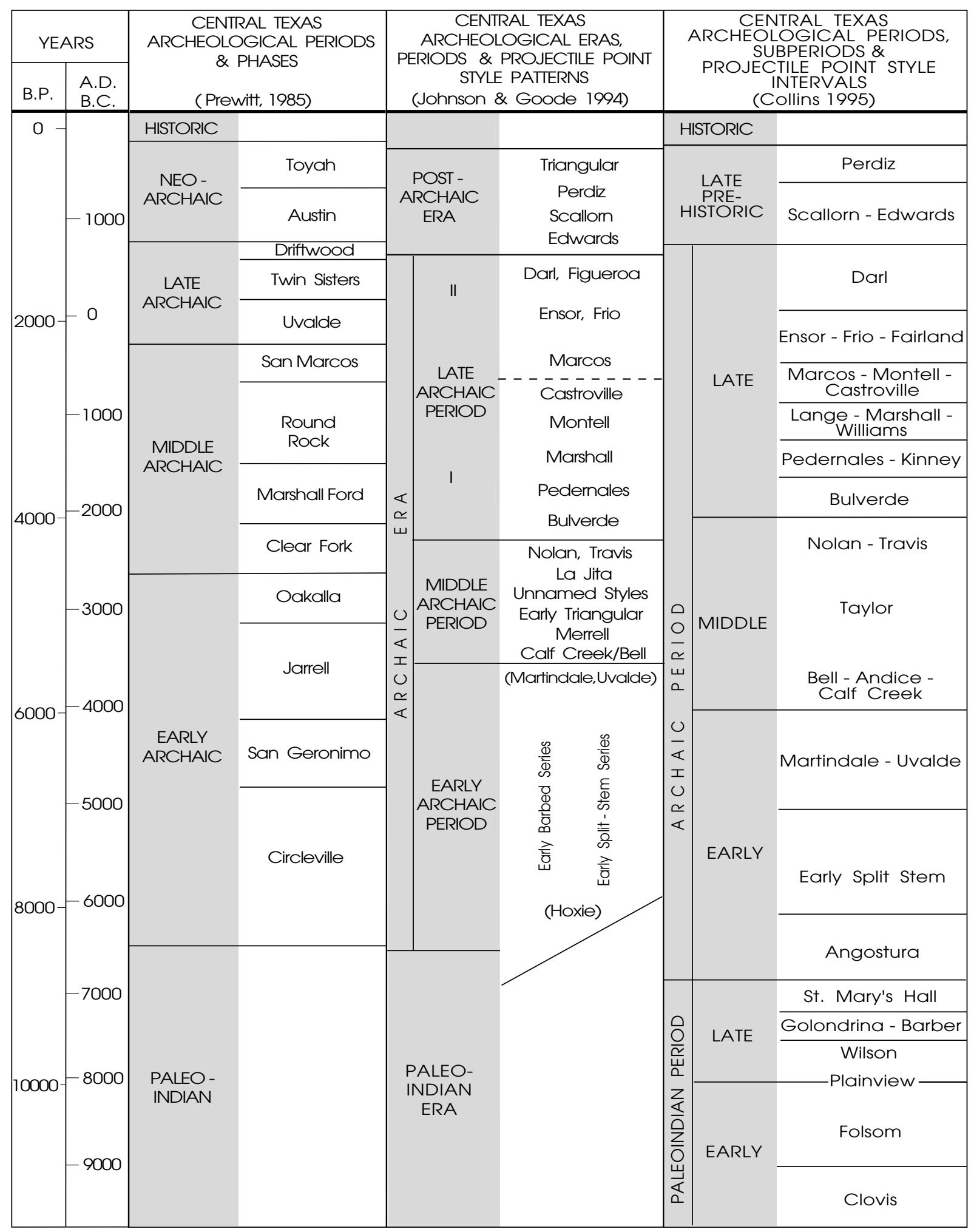

Figure 2.1. Prehistoric cultural sequences of Prewitt (1985: Figure 5), Johnson and Goode (1994:Figure 2), and Collins (1995:Table 2). 
bolas, and ochre (Collins 1995:381; Collins et al. 1992). Clovis artifacts suggest well-adapted, generalized hunter-gatherers who possessed the technology to hunt larger game but did not solely rely on it. In contrast, Folsom tool kits are more indicative of specialized hunting, particularly of bison (Collins 1995:382). Folsom artifacts consist of fluted Folsom points, thin unfluted (Midland) points, large thin bifaces, and end scrapers.

Spanning the late Paleoindian subperiod are several projectile point styles for which temporal, technological, or cultural significance is unclear. Plainview, a type name typically assigned to any unfluted, lanceolate Paleoindian point, is one example. Collins (1995:382) had noted that most of these points are not similar to the Plainview type-site points in thinness and flaking technology. Also problematic are the chronological position and cultural significance of Dalton and San Patrice dart points. The succeeding late Paleoindian subperiod includes three projectile point style intervals: Wilson (ca. 10,000-9650 в.P.), Golondrina-Barber, and St. Mary's Hall (9500-8800 B.P.). Components and artifact and feature assemblages of these three intervals appear to be Archaic-like in nature and in many ways may represent a transition between the early Paleoindian and succeeding Archaic periods (Collins 1995:382).

The Archaic period ( 8800 to $1300-1200$ B.P.) is generally believed to represent a shift toward hunting and gathering of a wider array of animal and plant resources and a decrease in group mobility (Willey and Phillips 1958:107-108), although such changes may have been well underway by the beginning of the period. Throughout the ca. 7,600-year-long period, major climatic changes probably presented Archaic populations with varying subsistence challenges. The Archaic is generally subdivided into Early, Middle, and Late subperiods (Black 1989; Collins 1995; Story 1985:28-29). Each of the three Archaic subperiods includes several temporal-stylistic units or intervals based on diagnostic projectile point styles and associated radiocarbon assays (Collins 1995).

Early Archaic (8800-6000 B.P.) sites are small, and their tool assemblages are very diverse (Weir 1976:115-122). This suggests that groups were highly mobile and that population densities were low (Prewitt 1985:217). It has been noted that Early Archaic sites were concentrated along the eastern and southern margins of the Edwards Plateau (Johnson and Goode 1994; McKinney
1981). This distribution may be indicative of climatic conditions at the time, as these environments had many more-reliable water sources and a diverse subsistence base. Microfaunal records and sedimentary evidence from stream valleys and caves along the eastern Edwards Plateau depict a climatic regime in flux, from mesic conditions during the beginning of the Early Archaic to extremely xeric and back to mildly xeric conditions at the end of the subperiod (Collins et al. 1990; Toomey et al. 1993). Three projectile point style intervals are recognized: Angostura; Early Split Stem, including Gower and Jetta; and Martindale-Uvalde. Manos, metates, hammerstones, Clear Fork tools, and a variety of other bifacial and unifacial tools are common to all three intervals, while Guadalupe bifaces on commonly associated with the Martindale-Uvalde interval. The construction and use of rock hearths and ovens reflect a specialized subsistence strategy (exploitation of roots, bulbs, and tubers) during the Early Archaic. These burned rock features most likely represent the technological predecessors of the larger burned rock middens used extensively later in the Archaic period (Collins 1995:383).

During the Middle Archaic period (60004000 в.P.) the number and distribution of sites, as well as site size, increased due to probable increases in population densities beginning ca. 5000-4500 в.P. (Prewitt 1981:73; Weir 1976:124, 135). Macrobands may have formed at least seasonally, or increased numbers of small groups may have used the same sites for longer periods of time (Weir 1976:130-131). A shift in the technology of processing plant foods is suggested by the presence of burned rock middens toward the end of the Middle Archaic, although tool kits still imply a strong reliance on hunting (Prewitt 1985:222-226). Three projectile point style intervals comprise the Middle Archaic: Bell-Andice-Calf Creek, Taylor, and Nolan-Travis. The Bell-Andice-Calf Creek and Taylor intervals reflect a shift in lithic technology from the preceding Martindale-Uvalde (Collins 1995:384).

Johnson and Goode (1994:25) suggest that the Bell-Andice-Calf Creek interval represents an influx of bison-hunting groups from the Eastern Woodland margins into the central Texas region during a slightly more-mesic period. Bison disappeared as more-xeric conditions returned during the Nolan-Travis interval. This style change represents another shift in lithic technology (Collins 1995:384; Johnson 
and Goode 1994:27). Prewitt (personal communication 1997) postulates that the production and morphology of Travis and Nolan points are similar to projectile points from the Lower Pecos region. Such characteristics as beveled stems and overall morphology may have originated in the Lower Pecos, since their presence there predates their appearance in central Texas. The accompanying change to more-xeric conditions bears witness to the construction and use of burned rock middens. Johnson and Goode (1994:26) speculate that dry conditions may have promoted the spread of xerophytic plants such as yucca and sotol, and that these plants were collected and cooked in large rock ovens by late Middle Archaic peoples.

Both Collins (1995) and Johnson and Goode (1994) recognize a period of extreme aridity in central Texas during the Archaic period. However, Collins (1995), as well as Nordt et al. (1994) and Toomey et al. (1993), views these xeric conditions as the culmination of a continual decrease in effective moisture since the end of the Pleistocene, while Johnson and Goode (1994) do not. In addition, Johnson and Goode (1994) believe that the period of aridity (their Edwards Interval) occurred slightly later, at ca. 4250-2550 в.P., compared to Collins'(995) much longer Altithermal climate at 8500-6800 and 5500-3000 в.P.

During the succeeding Late Archaic period (4000 to $1300-1200$ B.P.), populations continued to increase (Prewitt 1985:217). The establishment of large cemeteries along drainages suggests strong territorial ties by certain groups (Story 1985:40). Xeric conditions gave way to more mesic conditions ca. 3500-2500 B.P. The Late Archaic subperiod encompasses six projectile point style intervals (Collins 1995:376): Bulverde, Pedernales-Kinney, LangeMarshall-Williams, Marcos-Montell-Castroville, Ensor-Frio-Fairland, and Darl. Johnson and Goode (1994:29-35) divide the Late Archaic into two parts-Late Archaic I and Late Archaic IIbased on increased population densities and evidence of Eastern Woodland ceremonial rituals and religious ideological influences. Middle Archaic subsistence technology, including the use of burned rock middens, continued into the Late Archaic period. According to Collins (1995:384), the construction and use of burned rock middens reached a zenith during the Pedernales-Kinney interval and declined during the latter half of the
Late Archaic. However, mounting chronological data suggest that midden formation and use culminated much later, during the Ensor-FrioFairland and Darl intervals, and that this high level of use continued into the Late Prehistoric period (Black et al. 1997; Kleinbach et al. 1995:795). That burned rock midden use in the eastern part of central Texas was prevalent after 2000 в.P. is clear (Black et al. 1997: Figure 133). This scenario parallels the widely recognized occurrence of post- 2000 B.P. middens in the western reaches of the Edwards Plateau (Goode 1991). The use of burned rock middens appears to have been a major part of the subsistence strategy as a decrease in the importance of hunting, implied by the low ratios of projectile points to other tools in site assemblages, may have occurred (Prewitt 1981:74).

The Late Prehistoric period (ca. 1300-1200 to 300 B.P.) is marked first by the introduction of the bow and arrow into the region, and later by the appearance of ceramics. These innovations probably came from the north, by persons or mechanisms unknown (Prewitt 1985:228). Population densities dropped considerably from their Late Archaic peak (Prewitt 1985:217), and the use of burned rock middens for plant food processing continued throughout the period (Black et al. 1997; Goode 1991; Kleinbach et al. 1995:795). Subsistence strategies did not differ greatly from the preceding period, though bison became an important economic resource during the later part of the Late Prehistoric period (Prewitt 1981:74). Horticulture came into play very late in central Texas and was of minor importance to the overall subsistence strategy (Collins 1995:385).

In central Texas, the Late Prehistoric period is generally associated with the Austin and Toyah phases (Jelks 1962; Prewitt 1981:82-84); however, both phases have a much wider application. Austin and Toyah phase markers-Scallorn-Edwards and Perdiz arrow points, respectively-are distributed across most of the state. The introduction of Scallorn and Edwards points into central Texas is often marked by evidence of violence and conflict; many excavated burials from this period contain these arrow tips in contexts indicating that they were the cause of death (Prewitt 1981:83). Subsistence strategies and technologies (other than the shift from dart to arrow points) did not change much from the preceding Late Archaic. This continuity is recognized by 
Prewitt's (1981) use of the term "Neoarchaic." In fact, Johnson and Goode (1994:39-40) and Collins (1995:385) state that the break between the Late Archaic and the Late Prehistoric could easily and appropriately be represented by the break between the Austin and Toyah phases.

Around 1000-750 B.P., slightly more-xeric or drought-prone climatic conditions returned to the region, and bison came back to the region in large numbers (Huebner 1991; Toomey et al. 1993). Utilizing this vast resource were Toyahphase peoples equipped with Perdiz-tipped arrows, end scrapers, four-beveled knives, and plain bone-tempered ceramics. The technology and subsistence strategies of the Toyah phase represent a completely different tradition than the preceding Austin phase. Collins (1995:388) states that burned rock middens fell out of use as bison hunting and group mobility obtained a level of importance not witnessed since Folsom times. While the importance of bison hunting and high group mobility can hardly be disputed, the cessation of burned rock midden use during the Toyah phase is tenuous. A recent examination of Toyah-age radiocarbon assays and assemblages by Black et al. (1997:281-282) suggests that their association with burned rock middens represents more than a "thin veneer" capping Archaic-age features. They demonstrate that burned rock midden use, while not as prevalent as in preceding periods, still played an important role in the adaptive strategies of Toyah peoples.

Historical accounts of Native Americans and their interactions with the Spanish, the Republic of Mexico, the Texas Republic, and the United States throughout the region are provided by Bolton (1915), Campbell (1988), Campbell and Campbell (1981), Hester (1989), and Newcomb (1961). Collins (1995:386) divides this period into three subperiods. While initial European contacts with Native Americans in Texas occurred in the sixteenth century, the late seventeenth and early eighteenth centuries mark an era of more-permanent contact between Europeans and Native Americans as the Spanish moved northward out of Mexico to establish settlements and missions on their northern frontier. There is little available information on aboriginal groups and their lifeways except for fragmentary data gathered by the Spanish missionaries. Much of this sketchy evidence comes from the San Antonio and South Texas areas. Groups in these areas have been referred to collectively as Coahuiltecans because of an assumed similar lifestyle. However, many individual groups undoubtedly existed (Campbell 1988). The inevitable and disastrous impacts to native social structure and economic systems by disease and hostile encounters with Europeans and intruding groups, such as the Apache, were already underway at this time.

The second subperiod spans the establishment of the mission system in the 1720 s to its ultimate demise around 1800. Some indigenous groups moved peacefully into the Spanish missions, giving up their nomadic hunting and gathering way of life; others were forced in to escape the increasingly hostile actions of southwardadvancing Apaches and Comanches. By the end of this time, many Native American groups had been decimated by European expansion and disease. Intrusive groups, such as the Tonkawa, Apache, and Comanche, moved into the region to fill the void. Few sites attributable to these groups, outside the mission sites, have been investigated. To complicate matters, many aboriginal lifestyles continued after Spanish contact. For example, many groups continued to manufacture stone tools even after settling in the missions (Fox 1979).

The third subperiod, from 1800 to the last half of the nineteenth century, witnessed the final decimation of indigenous groups and the defeat and removal of the Apaches and Comanches to reservations by the United States.

\section{PREVIOUS INVESTIGATIONS AT 41CV1636}

Prewitt and Associates archeologists recorded 41CV1636 in August 2005 during an intensive survey of new right of way needed for the proposed widening of Highway 84 (McWilliams 2005; McWilliams and Kibler 2006). Cultural materials were recorded in 1 of 12 trenches (Trench 3) excavated across the western floodplain. The site was recorded as a deposit of burned rock clusters and a dense lens of lithic debitage found between 20 and $100 \mathrm{~cm}$ below the ground surface and concentrated between 40 and $60 \mathrm{~cm}$. Two Pedernales dart points and 1 Provisional Type 1 point were recovered from the backdirt of Trench 3 . In addition, many flakes (an estimated 60-70), 2 crude bifaces, 1 core, Rabdotus sp. Shells, and mussel shell fragments were observed. Burned rock clusters and debitage were also observed in the trench floor and walls. Additional trenches were excavated a 
distance of $20 \mathrm{~m}$ or less from Trench 3. No debitage was encountered in the other trenches, but isolated burned rocks were noted. One 50x50$\mathrm{cm}$ shovel test was placed off the south side of Trench 3, near the eastern end. The shovel test was excavated in 20-cm levels, and matrix was screened through a 1/4-inch-mesh hardware cloth. No cultural material was recovered from the first level. Level $2(20-40 \mathrm{cmbs})$ produced 7 flakes and 4 burned rocks. Seventeen flakes and 2 burned rocks were recovered from Level 4 (60$80 \mathrm{cmbs})$, and Level 5 (80-100 cmbs) produced 11 flakes and 3 burned rocks. The results of the initial survey were insufficient to determine the site's eligibility for listing in the National Register of Historic Places or designation as a State Archeological Landmark, so testing was recommended. 


\section{METHODS OF INVESTIGATION AND WORK ACCOMPLISHED}

This chapter summarizes the methods used and work accomplished in accordance with National Register of Historic Places testing at 41CV1636 (Figure 3.1). Test excavations consisted of re-excavation of Trench 3 from the initial 2005 survey. A new trench (Trench 13) was excavated between Trench 3 and Trench 6 to further define the site boundaries; Trench 13 was $4 \mathrm{~m}$ east of the eastern end of Trench 3 and extended to within $4 \mathrm{~m}$ of the western end of Trench 6 . While excavating the backfill from Trench 3 , it became evident that burned rocks continued into the floor of the trench and that a deeper excavation may be needed to better define the lower boundary of the cultural deposits. The east end of Trench 3 was excavated to a depth of $2.8 \mathrm{~m}$. Burned rocks decreased below $1.2 \mathrm{~m}$ in depth, but isolated burned rocks continued to appear in the walls of the trench down to $1.9 \mathrm{~m}$.

\section{FIELD METHODS}

The scope of work called for three test units along Trench 3 and a fourth test unit along Trench 13 to investigate deposits along the eastern boundary of the new right of way. Placement of all units was predicated on examining cultural materials and possible features observed in the two trenches. All units were placed beside backhoe trenches in areas deemed best for sampling cultural deposits (ie., where clusters of burned rocks were noted while excavating the trenches). Test Unit 1 was placed near Shovel Test 1 from survey in an area where a cluster of burned rocks had been observed continuing into the southern wall of Trench 3. Test Unit 2 was placed on the northern side of Trench 3 near the western end to investigate the far northern extent of the site.
Test Unit 3 was also placed on the north side of Trench 3 but near the far eastern end in what was thought to be the eastern extent of the most-concentrated portion of the site. Finally, Test Unit 4 was placed off the north side of Trench 13 where a cluster of burned rocks had been observed near the western end of the trench. As dictated by the scope of work, excavation of each test unit was terminated at ca. $120 \mathrm{~cm}$ below the ground surface. However, preliminary artifact counts showed that substantial cultural material was still coming out of the lower levels, and excavation of additional levels was considered warranted. Two units, Test Units 2 and 4, were divided into equal halves, and one $1.0 \times 0.5 \mathrm{~m}$ half in each was taken down four additional levels to $160 \mathrm{~cm}$ below the surface. In total, $5.2 \mathrm{~m}^{3}$ of the site were excavated by hand and water screened.

Because the soil at 41CV1636 is dense clay, a water-screening system was implemented during site testing efforts. The backhoe excavated a ca. $5 \times 8-m$ sump off of the western end of the site, and the sump was then filled with water. Personnel from TxDOT erected a silt fence to prevent runoff silt from entering the waterways. As excavation proceeded, each 10 -cm level was put into 5 -gallon buckets (usually 12-15 buckets per level). The soil was soaked in a mixture of baking soda ( $\mathrm{NaHCO} 3)$ and water and screened through 1/4-inch-mesh hardware cloth using high-pressure water. Initially, less baking soda was used —one 240-g scoop per bucket-but it became apparent that more baking soda could easily be added to aid in water screening, and two scoops were used per bucket. Over the course of the project, eleven $22.7 \mathrm{~kg}$ bags were used to process 5.2 cubic meters of matrix from the site. Therefore, $48 \mathrm{~kg}$ of baking soda was used per cubic meter. 


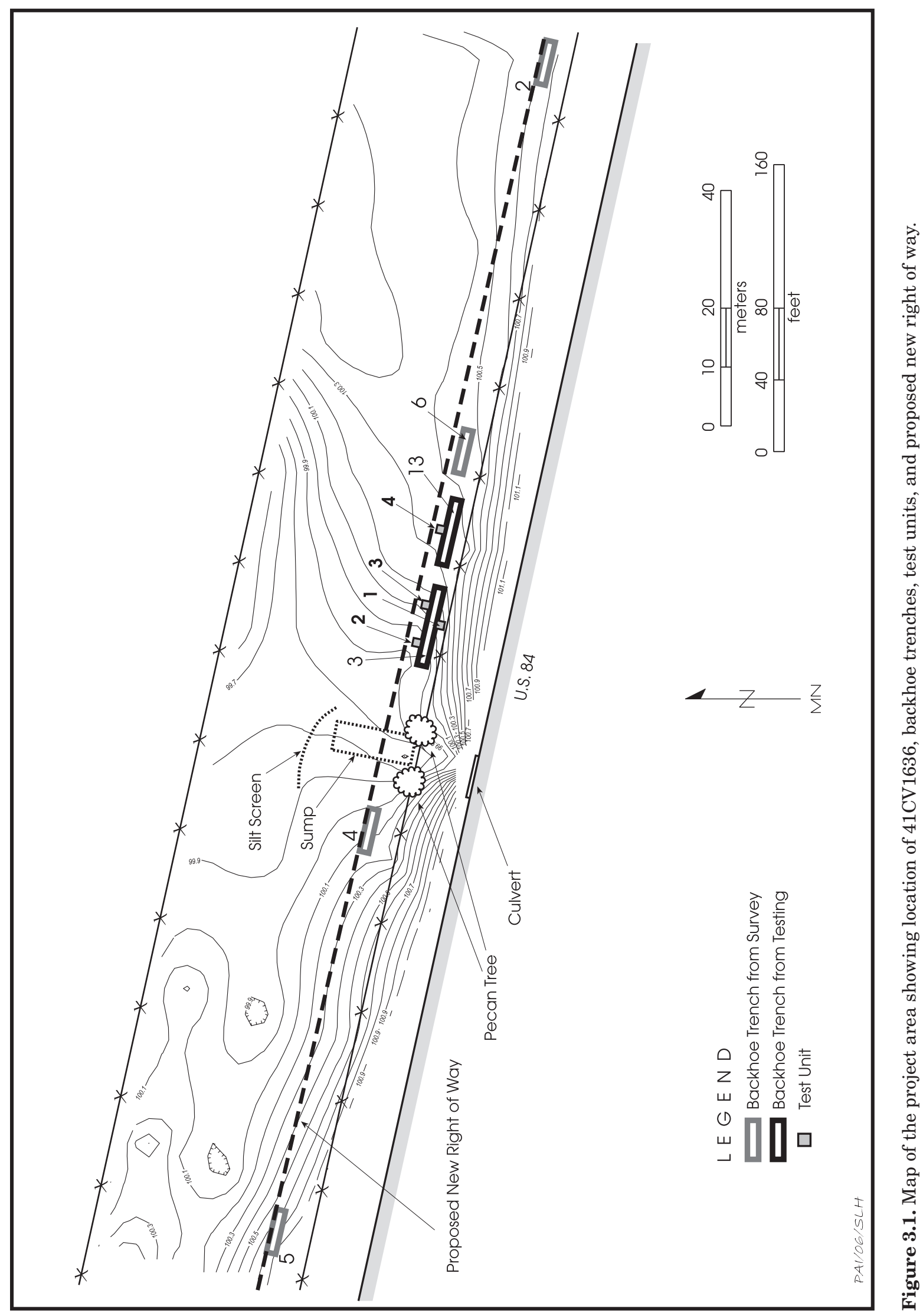


Most of the cultural materials recovered from the $1 / 4$-inch screening were bagged in the field and returned to PAI's laboratory. Chipped stone artifacts were counted and recorded in the field and collected for curation. Burned rocks (pieces larger than $3-4 \mathrm{~cm}$ ) and weighed in the field but not collected. Burned rocks from nonfeature contexts were divided into size-range categories, counted, and weighed in the field but not collected. Bones were counted and collected. Mussel shell umbos were collected but not shell fragments. Only whole Rabdotus sp. shells were counted but were not collected. Chipped stone tools, debitage, bones, shell umbos, and hinge teeth were bagged separately and put into a larger bag representing each level or feature provenience. All relevant provenience data was labeled on each bag before it left the field. Artifact counts by test unit and level were recorded in the field on a water-screening log to assist in tracking artifact frequencies and distributions across the site as excavation progressed.

Flotation samples were collected from two units; each was taken from one-quarter of two to three levels. Flotation samples were also taken from features. All flotation samples were labeled with relevant provenience information. All numbered features were recorded using a standard PAI Feature Form. Soil stratigraphy was recorded and described for both of the trenches by the geoarcheologist, and test unit walls were drawn after excavation was complete. Mapping was conducted using a Total Data Station set at an arbitrary elevation of $100.00 \mathrm{~m}$. The site datum, identified as an inscribed " $\mathrm{X}$ " on the floor of Culvert 19, lies immediately west of the site. A map was produced of topographic features, the highway, culvert, fence lines, power poles, vegetation, and the locations of five of the initial survey trenches and the shovel test, in addition to the new trench, test units, the sump, and the protective silt fence.

\section{LABORATORY METHODS}

All artifact and material collections were processed and curated according to federal curation guidelines, the Council of Texas Archeologists' Standards, and current curation and conservation standards. Laboratory processing took place during January and entailed washing, identifying, and cataloging all cultural materials collected from 41CV1636.
Artifact analysis was limited to classifying materials by material and functional groups. Flotation of all sediments removed from two of the test units and two cultural features was accomplished. Collecting and classifying all identifiable pieces of cultural material-specifically at this level, looking for charcoal-was an important step to assessing the site's potential to yield important information.

Once material was in the laboratory, all field bags were checked against a master field log and then processed for cleaning in the wet lab. Following cleaning, artifacts and other materials were bagged by material type with associated provenience designations and correlated with a specimen inventory list. All categories of artifacts were cataloged with the site and accession numbers. Lithic tools were assigned unique specimen numbers within each accession number. Artifacts and other materials were then bagged for curation.

Flotation samples were processed using a Flote-Tech flotation system. The result is a light fraction destined for special analyses (such as macrobotanical) and a heavy fraction that was checked for artifacts and faunal remains. Roots and unmodified rocks were removed and discarded. Any artifacts found in flotation samples were processed for curation following the procedures outlined above. These artifacts were counted and/or weighed but were not subjected to further analysis.

All photographs were keyed to a photo log identifying the subject, direction of view, date, and photographer. All photographs, negatives, and slides were checked against the photo logs to ensure that frame numbers and captions correlated and that the recorded information was accurate. All of the photographic materials were placed into appropriate archival holders.

All forms and records used in the field and the lab were printed on archival paper and filled out in pencil. All records were then processed and organized for use during the analysis and report preparation before final curation with the artifacts.

\section{ANALYTICAL METHODS}

Due to the small number of formal and informal artifacts recovered, each artifact was individually described for this report. Descriptions generally followed methods of analysis 
used in archeological studies recently conducted for sites on Fort Hood (Arnn et al. 2000; Mehalchick et al. 1999, 2002). Also due to the small artifact sample size, limited emphasis is placed on deriving or inferring tool functional information from the analysis.

The discussion and interpretation of formal and informal tools is based on examination of each tool for suites of attributes that are typically individually coded in studies with larger samples. The reader is referred to Arnn et al. (2000), Mehalchick et al. (1999, 2002), Kleinbach et al. (1999), Trierweiler (1994), and Abbott and Trierweiler (1995) for detail on the application of such attribute analyses at Fort Hood. The logic and approach of these analyses forms the basis of this current study. Although the attribute analysis methods employed for Fort Hood are flexible and allow for a wide variety of artifact types, there were only a limited number of chipped stone artifact categories represented in the 41CV1636 assemblage: dart points and fragments, biface fragments, uniface fragments, utilized flakes, cores and tested cobble, and debitage. Greater emphasis has been placed on morphological and technological information that can be derived from describing the chipped artifact assemblage.

A similar emphasis will also be noted in the debitage analysis that consists of a streamlined approach emphasizing raw material, cortex presence and type, size grades, and flake type rather than a detailed metric and technological analysis. Selected attributes that were coded during the debitage analysis are discussed below.

\section{Size Grade}

Debitage analysis included data recording of eight maximum size classes: $(1)<0.25$ inch; (2) 0.25-0.38 inch; (3) 0.38-0.50 inch; (4) 0.50-0.75 inch; (5) $0.75-1.00$ inch; (6) 1.00-1.50 inches; (7) 1.5-2.0 inches; (8) > 2.0 inches. These size categories are identical to those used in previous analyses of unmodified debitage conducted by Texas A\&M, Mariah Associates, Inc., and Prewitt and Associates, Inc. All complete flakes and flake fragments from 41CV1636 were size graded by this system. Size grading was also selected because it allows the analyst to process large amounts of debitage in a short amount of time.

\section{Cortex}

The amount of cortex present on a chipped stone artifact can provide information on the raw material source, methods of obtaining raw material, and manufacture stage. Cortex on each chipped stone artifact (the exception being projectile points) and all complete and broken unmodified flakes was recorded as 0 percent, 0-50 percent, 50-99 percent, or 100 percent. Where possible, observations were made on the characteristics of cortex, such as streamworn, chalky, streamworn/chalky, or patina. Classification of cortex types provides information on the probable procurement origin of lithic raw material. Chalky or nodular cortex is identifiable by its whitish or variously stained color and unweathered appearance. Following Masson (1998:692), this type of cortex possibly represents chert material quarried from such sources as geological exposures, cutbanks, or other recently exposed sources. Cortex that exhibits a weathered appearance would represent material possibly procured from upland surface exposures of nodular material. Masson (1998:692) identified similar cortex as "upland residual cortex."

\section{Chert Type}

A variety of raw materials are typically identified among chipped and groundstone lithic assemblages. Common materials are chert, quartz, quartzite, limestone, sandstone, or a variety of other igneous and metamorphic rock types. Chert represents the most abundant raw material type in the 41CV1636 lithic assemblage. All chert artifacts, regardless of artifact type, were compared with the established Fort Hood chert typology (Table 3.1). Due to the location of the site directly along Cowhouse Creek, the assemblage yielded an opportunity to consider the possible presence and importance of established chert types beyond the boundaries of the Fort Hood military reservation. Even if none of these chert types can be identified, the result will provide a unique point of comparison to previous and future studies of lithic assemblages from the Fort Hood area. Typological studies of Fort Hood cherts have been conducted by Abbott and Trierweiler (Abbott and Trierweiler 1995; Trierweiler 1994), Dickens (1993a, 1993b), and Frederick and Ringstaff (1994). Of particular importance 
Table 3.1. Fort Hood chert types grouped according to bedrock and alluvial gravel sources

\begin{tabular}{|c|c|c|}
\hline $\begin{array}{c}\text { Type } \\
\text { Number }\end{array}$ & Type Name & Abbreviation \\
\hline \multicolumn{3}{|c|}{ Types Occurring as Bedrock and Non-Alluvial Sources: } \\
\hline 1 & Heiner Lake Blue-Light & HLB-LT \\
\hline 2 & Cowhouse White & $\mathrm{CW}$ \\
\hline 3 & Anderson Mountain Gray & AMG \\
\hline 4 & Seven Mile Mountain Novaculite & SMN \\
\hline 5 & Texas Novaculite & $\mathrm{TN}$ \\
\hline 6 & Heiner Lake Tan & HLT \\
\hline 7 & Fossiliferous Pale Brown & FPB \\
\hline 8 & Fort Hood Yellow & FHY \\
\hline 9 & Heiner Lake Translucent Brown & HLTB \\
\hline 10 & Heiner Lake Blue & HLB \\
\hline 11 & East Range Flat & ERF \\
\hline 13 & East Range Flecked & ER FLECKED \\
\hline 14 & Fort Hood Gray & FHG \\
\hline 15 & Gray-Brown-Green & GBG \\
\hline 16 & Leona Park & LP \\
\hline 17 & Owl Creek Black & OCB \\
\hline \multicolumn{3}{|c|}{ Types Occurring as Channel Gravel Sources: } \\
\hline 18 & Cowhouse Two Tone & CTT \\
\hline 19 & Cowhouse Dark Gray & CDG \\
\hline 20 & Cowhouse Shell Hash & $\mathrm{CSH}$ \\
\hline 21 & Cowhouse Light Gray & CLG \\
\hline 22 & Cowhouse Mottled with Flecks & $\mathrm{CMF}$ \\
\hline 23 & Cowhouse Banded and Mottled & $\mathrm{CBM}$ \\
\hline 24 & Cowhouse Fossiliferous Light Brown & CFLB \\
\hline 25 & Cowhouse Brown Flecked & $\mathrm{CBF}$ \\
\hline 26 & Cowhouse Streaked & $\mathrm{CS}$ \\
\hline 27 & Cowhouse Novaculite & $\mathrm{CN}$ \\
\hline 28 & Table Rock Flat & TRF \\
\hline
\end{tabular}

are the 10 known chert types that are known to occur in alluvial contexts within Cowhouse Creek (see Table 3.1) as it flows through Fort Hood and empties into Lake Belton. A more recent study from Fort Hood makes a strong case against the validity of some previously named chert types (Boyd 1999:363-380).

\section{Flake Type}

The identification of particular flake types in unmodified debitage assemblages is commonly key to interpretations of lithic technology, stone tool manufacture, and core reduction strategies (Andrefsky 2000:23-29). For this study, analytical effort focused on size variability within the unmodified debitage assemblage and size variability among identified flake types. A series of flake types were included in the analysis, although not all of these flake types were found in the assemblage. Note that the flake types only identify the general modes of flake production used and that there is undoubtedly technological overlap between flake types. In other words, different flake types can be produced by the same flaking technique, and different techniques can produce flakes with identical morphologies. Definitions and key attributes of each flake type are provided in Table 3.2.

\section{Burned Rocks}

All non-chert rocks (primarily limestone) that exhibit evidence of heating such as thermal discoloration, angular fractures, or spalling were categorized as burned rocks. Thermally altered rocks encountered in hand excavations were sorted by size and weighed and then discarded if no other modifications were identified. Some burned rocks were directly associated with heating/cooking features and others were associated with general midden deposits. All of these burned rocks are considered to have been heated intentionally and were probably used as heat-retaining stones in a heating/cooking feature.

\section{Faunal Remains}

Poorly preserved faunal material and postdepositional factors were significant limiting agents on the amount of information that could be retrieved from the recovered faunal material recovered from 41CV1636. Consequently, the amount of information normally included in a faunal analysis was not possible, and the analysis and interpretations presented are of more limited scope.

Invertebrate faunal remains consisted of a small number of freshwater mussel shell umbos and hinge teeth. These fragments are thought 
Table 3.2. Flake types and critical technological attributes

\begin{tabular}{|c|c|}
\hline Flake Type & Attributes \\
\hline Bifacial thinning & $\begin{array}{l}\text { No bulb of percussion and the presence of a distinct lip or ridge on the } \\
\text { ventral aspect or edge of the striking platform. Some may have a waisted } \\
\text { or constricted appearance just below the striking platform. Profile shape } \\
\text { is typically arched and planview is often expanding distally. Crushed or } \\
\text { collapsed platforms may be present because excessive force was used } \\
\text { during flaking and flake thinness. Dorsal flake scarring is common. }\end{array}$ \\
\hline Hardhammer core reduction & $\begin{array}{l}\text { Typically has an exuberant or prounounced bulb of percussion and } \\
\text { thickened cross section. Flake shape is variable. }\end{array}$ \\
\hline Bifacial core reduction & $\begin{array}{l}\text { Like the bifacial thinning flake, the bifacial core reduction has a generally } \\
\text { arched profile, a thin cross section, and many dorsal flake scars. However, } \\
\text { it is generally larger than a bending flake. It typically has a bulb of } \\
\text { percussion and a multifaceted striking platform. Profile shape in planview } \\
\text { is often expanding distally. Platform morphology and dorsal flake scar } \\
\text { patterns vary. }\end{array}$ \\
\hline Wedging (bipolar) & $\begin{array}{l}\text { No bulbs of percussion or only sheared bulbs present. Ripple marks and } \\
\text { crushed and sheared faces on opposed ends of fracture surface indicating } \\
\text { force from opposing directions. Can be associated with abundant non- } \\
\text { diagnostic shatter when present in an assemblage. }\end{array}$ \\
\hline Pressure & $\begin{array}{l}\text { Typically laminar or elongate tonguelike shapes with a small contact } \\
\text { platform area. Some pressure flakes may be constricted below the striking } \\
\text { platform because the platform was isolated by pressure flaking before } \\
\text { flake removal (Whittaker 1994:147). Common to observe very small bulbs } \\
\text { of percussion produced during static loading. Crushed platforms and } \\
\text { broken flakes are common due to thinness. }\end{array}$ \\
\hline Notching & $\begin{array}{l}\text { Can be produced by pressure or punch techniques. Flakes are typically } \\
\text { C- or S-shaped with previous C- or S-shaped dorsal flake scars where } \\
\text { removed in sequence. Platforms are typically singe-faceted (Titmus 1985; } \\
\text { Weber 1994:635). Notching flakes expand laterally and ventrally like the } \\
\text { Hertzian cone. }\end{array}$ \\
\hline Overshot & $\begin{array}{l}\text { Overshot flakes can be either bending or conchoidal initiated but preserve } \\
\text { a remnant of opposing lateral edges of the biface or have striking platform } \\
\text { on the proximal end. The distal end terminates in removal of a portion of } \\
\text { the biface edge. Created by use of excessive force in flaking. }\end{array}$ \\
\hline Biface edge collapse & $\begin{array}{l}\text { Both faces of the biface lateral edge are preserved on the proximal end as } \\
\text { the striking platform. This would create a corresponding open C-shape } \\
\text { along the edge of the biface. Produced as a result of manufacturing error. } \\
\text { Termination morphology is variable (Masson 1994:686). }\end{array}$ \\
\hline Resharpening & $\begin{array}{l}\text { Flake size is typically small }(<20 \mathrm{~mm}) \text { and flake shape varies from } \\
\text { parallel edged to slightly expanding with typically less than } 3 \text { dorsal flake } \\
\text { scars. Can be either Hertzian or bending initiation and appear as small } \\
\text { biface thinnning flakes in shape. May be representative of late-stage } \\
\text { biface shaping/finishing or flake tool retouch. Incorporates aspects of } \\
\text { Masson's (1994:686) "thin edge trimming" and "microflake" flake type } \\
\text { categories. }\end{array}$ \\
\hline Punch & $\begin{array}{l}\text { Similar striking platform morphology as notching flakes but variable } \\
\text { flake morphology. When viewed from above onto the striking platform, } \\
\text { there is a pronounced gull-wing appearance to the flake. Exuberant bulb } \\
\text { of percussion or corresponding deep negative bulbar scar on biface. }\end{array}$ \\
\hline $\begin{array}{l}\text { Uniface } \\
\text { manufacture/resharpening }\end{array}$ & $\begin{array}{l}\text { Striking platforms typically rounded, stepped, or crushed from use wear. } \\
\text { Use wear present on dorsal surface trailing distally from the striking } \\
\text { platform is common. Retouch technique dictates presence or absence of } \\
\text { bulb of percussion. Previous dorsal flake scars can be common and } \\
\text { represent previous edge retouch removals. Retouch flakes have an arced } \\
\text { profile. Can expand distally or have mostly parallel lateral edges. In }\end{array}$ \\
\hline
\end{tabular}


Table 3.2, continued

\begin{tabular}{|c|c|}
\hline Flake Type & Attributes \\
\hline & profile the distal termination is curved (Andrefsky 1998:120). \\
\hline Core platform rejuvenation & $\begin{array}{l}\text { Sections or flakes removed from core platforms or surfaces to rejuvenate } \\
\text { or repair the core for continued flaking. Commonly removed from } \\
\text { unidirectional and blade and flake blade cores. Core tablets represent } \\
\text { disc-shaped flakes with remnant flake removal scars around the lateral } \\
\text { edge (portion or all). These flakes were removed to renew the striking } \\
\text { platform. }\end{array}$ \\
\hline Hammerstone spall & $\begin{array}{l}\text { Dorsal surfaces consisting of heavily battered surfaces and flake scar } \\
\text { ridges. Typically of limestone or quartz and quartzite with no evidence of } \\
\text { burning to suggest a thermal spall. In absence of hammerstones, can be } \\
\text { used to identify their use. }\end{array}$ \\
\hline $\begin{array}{l}\text { Blade, flake blade, or blade } \\
\text { blank }\end{array}$ & $\begin{array}{l}\text { Created either by hardhammer or softhammer percussion and usually at } \\
\text { least twice as long as they are wide. Not as uniform as true prismatic } \\
\text { blades in shape, size, or technology. }\end{array}$ \\
\hline Burin spall & $\begin{array}{l}\text { A byproduct of a burin technique, usually very narrow and thick, } \\
\text { generally terminating in a hinge or step. }\end{array}$ \\
\hline Other & $\begin{array}{l}\text { This category is reserved for flake types that do not appear to fall within } \\
\text { any of the above flake type categories. }\end{array}$ \\
\hline $\begin{array}{l}\text { Burned shatter/angular } \\
\text { pieces }\end{array}$ & $\begin{array}{l}\text { Fragments, chunks, and chips that could not be assigned to a particular } \\
\text { flake class or identified as a flake fragment and that exhibit various types } \\
\text { of burning or heat/thermal damage characteristics such as potlids, } \\
\text { crazing, and cracking. }\end{array}$ \\
\hline $\begin{array}{l}\text { Unburned shatter/angular } \\
\text { pieces }\end{array}$ & $\begin{array}{l}\text { All fragments, pieces, chunks, chips, etc. that could not be assigned to a } \\
\text { particular flake class or identified as a flake fragment. None of these } \\
\text { specimens exhibit evidence of burning or other heat alteration. }\end{array}$ \\
\hline Indeterminate & $\begin{array}{l}\text { This category is reserved for broken flake fragments that could not be } \\
\text { assigned to any of the above flake types. Includes primarily distal, medial, } \\
\text { or other flake segments without a striking platform. }\end{array}$ \\
\hline
\end{tabular}

to represent materials introduced by humans. Although most shells found in archeological contexts are thought to represent the byproducts of eating mussels, some shells were modified to make tools and ornaments. Shells that are discolored or calcined were probably heated intentionally, perhaps to open shells to remove the mussel. Some may have been burned incidentally by being tossed or incorporated into cooking/heating facilities. All unmodified mussel shells and fragments with a partial or whole umbo were collected; other fragments were noted when possible and discarded in the field. Any mussel valve or shell fragments exhibiting evidence of human modification were collected and are considered to be artifacts.

\section{Macrobotanical Remains}

Macrobotanical remains, including charcoal, were recovered from flotation samples and were identified when possible. Flotation samples from Features 1 and 2 failed to yield sufficient samples of preserved organic material to warrant a detailed analysis by a botanical specialist. Therefore, materials recovered from flotation samples are briefly presented in Appendix A as part of the overall inventory of recovered materials. 



\section{SITE STRATIGRAPHY AND DEFINITION OF ANALYSIS UNITS}

\section{STRATIGRAPHIC SETTING}

Site 41CV1636 is situated along the southeastern edge of a relict channel of Cowhouse Creek at an elevation of ca. $960 \mathrm{ft}$ amsl. The site lies in a long, narrow pasture that also functions as a periodic wet weather slough (McWilliams and Kibler 2006:1). At this location, Cowhouse Creek has a ca. 1.5-km-wide strip of Holocene alluvium (Bureau of Economic Geology 1970, 1976). The site is buried within this alluvium.

Sediments in the project area consist of alluvium and minor amounts of stony colluvium due to the site's location near the distal margin of the Cowhouse Creek floodplain and the adjacent valley wall (McWilliams and Kibler 2006:5). Soils in the vicinity of the site are associated with the Lewisville series (McCaleb 1985:65-66). Lewisville soils consist of well-drained, deep loamy deposits on major stream terraces that formed from calcareous older alluvial sediments.

Within Fort Hood, Nordt (1992:10-22) documented three alluvial landforms within the Cowhouse Creek drainage basin: the Pleistocene Terrace (T2), the Holocene Terrace (T1), and the modern channel and floodplain (T0). Nordt identified five principal alluvial units and one paleosol within the drainage basin. In order from oldest to youngest these are the Jackson alluvium, Georgetown alluvium, Fort Hood alluvium, West Range alluvium, and the Ford alluvium (Abbott 1994; Nordt 1992).

The Jackson alluvium is approximately 15,000 years old and is composed of 3 to $4 \mathrm{~m}$ of gravelly and loamy sediments forming the T2 terrace along Cowhouse Creek and the Leon River. The Jackson alluvium rests upon strath terraces of the Glen Rose limestone. Buried beneath the $\mathrm{T} 1$ terrace surface is the Georgetown alluvium, which is the oldest stratigraphic unit within the entrenched Holocene valley occupied by Cowhouse Creek. Georgetown unit deposition began ca. 11,300 B.P. and ended by ca. 8200 в.P. (Nordt 1992:20, 69). Profiles are between 4 and $6 \mathrm{~m}$ and consist of gravelly and loamy deposits. The Royalty paleosol developed atop the Georgetown alluvium and exhibits a truncated Bk horizon and secondary precipitates of calcium carbonate. The Fort Hood alluvium is the major Holocene unit along Cowhouse Creek and most of its tributaries. It consists of 9-10 m of gravelly and loamy deposits dating ca. 80004800 B.P. The West Range alluvium accumulated in two episodes between 4300 and 600 B.P. separated by a brief erosional period between 3000 and 2000 B.P. The West Range alluvium is characteristically ca. $9 \mathrm{~m}$ thick and partially truncates and overlies the Fort Hood alluvium in some areas. In many areas along Cowhouse Creek, the T1 terrace is diachronic because the Fort Hood and West Range alluviums aggraded to the same elevation. Between 400 and 600 years ago, deposition of the Ford alluvium and construction of the modern floodplain of Cowhouse Creek began and continues into the present. Colluvial and slopewash sediments also represent culturally important deposits along the valley walls, occurring as both thick lenses at the base of steeper slopes and thin mantles of material on the uplands (Abbott 1994:31).

Environmental data (Bryant and Holloway 1985; Nordt 1992) suggest a general warming trend across much of central and northwestern Texas beginning ca. $8000-6500$ B.P. and lasting until ca. 5000-4500 B.P. The warming period encompasses the alluviation and pedogenic 
history of the Fort Hood alluvium between 8000 and 4800 B.P. This period of regional climatic change appears to have been accompanied by measured deposition and pedogenesis, aeolian sedimentation, and alluvial fan deposition (see Nordt 1992:64 for a more detailed discussion).

\section{SEDIMENTS AND STRATIGRAPHY}

Site 41CV1636 displays a stratigraphic sequence comparable with the Fort Hood and West Range alluvium as identified from other sites located on Fort Hood. An A-Bt-Btk loamy soil profile with 1 percent granule- to pebblesized subangular gravels is dispersed throughout the profile. This soil imprint masks any stratigraphic break or boundary between the two alluvial units.

The profile examined in Trench 3 is $167 \mathrm{~cm}$ thick (Figures 4.1, 4.2, and 4.3). The upper $11 \mathrm{~cm}$ of the profile consists of backdirt from the previous excavation of the trench during survey, but below this, it displays an A-Bt-Btk soil profile. The A horizon (11-47 cm below surface) is a very dark gray (10YR 3/1) clay loam with a moderate blocky subangular structure. The Bt horizon (47-21 cm) is a dark grayish brown (10YR 4/2) silty clay loam. It displays a weak prismatic structure breaking to a moderate blocky angular structure. Clay films and faint manganese stains are present on the ped faces. The underlying Btk horizon $(121-167+\mathrm{cm})$ was a brown (7.5YR 4/3) clay loam. It also exhibits a prismatic structure breaking to a moderate blocky angular structure. Clay films and faint manganese stains are present on the ped faces, and carbonate filaments ( 5 percent) are dispersed throughout the horizon.

The 165-cm-thick profile of Trench 13 displays a similar A-Bt-Btk soil profile. The A horizon (0-44 cm below surface) consists of a very dark gray (10YR 3/1) silty clay loam with a moderate blocky subangular structure. The Bt horizon (44-113 cm below surface) is a very dark grayish brown (10YR 3/2) silty clay loam exhibiting a weak prismatic structure breaking to a moderate subangular blocky structure. Clay films are present on ped faces, as are small coatings of carbonate. The Btk horizon (113-165+ cm below surface) consisted of a brown (10YR 4/3) clay loam exhibiting a weak prismatic structure breaking to a moderate blocky angular struc- ture. Clay films and faint manganese stains are present on the ped faces. Test Unit 4 (Figure 4.4) has the same stratigraphic sequence described for Trench 13.

The soil stratigraphy of $41 \mathrm{CV} 1636$ reveals that the site was occupied as aggradation of the floodplain surface slowed and pedogenesis began. Based on temporally diagnostic artifacts, these occupations appear to have occurred over a short time span, but deposition of colluvial material from the adjacent valley wall and from periodic overbank flooding was not enough to provide sufficient vertical separation between occupations.

\section{DEFINITION OF ANALYSIS UNITS}

All materials recovered from testing at 41CV1636 were assigned to a single analysis unit. The analysis unit for 41CV1636 probably includes multiple short-term occupations on the slowly aggrading Fort Hood alluvium land surface (T1). It is not possible to separate discrete occupation events vertically or spatially within the deposits excavated at the site. The degree of patination observed on some artifacts and unmodified debitage at 41CV1636 suggests prolonged exposure to environmental factors such as would be expected of occupations on a slowly aggrading land surface such as the T1 terrace above Cowhouse Creek, although this oversimplifies the issue (Frederick et al. 1994). Nordt (1992:74-75) notes that portions of the T1 terrace above the Fort Hood alluvium that are near the valley walls contain small localized deposits or drapes of colluvial material. Soil development in these settings indicates that these surfaces may have been stable for 4,000-5,000 years. Sites on the T1 terrace near the valley wall would be encased within the colluvial drape and could have an occupational sequence from the Late Archaic to the early Late Prehistoric.

Given the absence of absolute chronological evidence, the analysis presented here is based on varying abundance of lithic materials in each level, total weight of burned rocks in each level, and the stratigraphic position of temporally diagnostic projectile points, fragments, tools, and faunal remains.

Test Units 1, 2, and 3 produced the highest densities of cultural materials. Test Unit 4 yielded the lowest densities of cultural materials, 


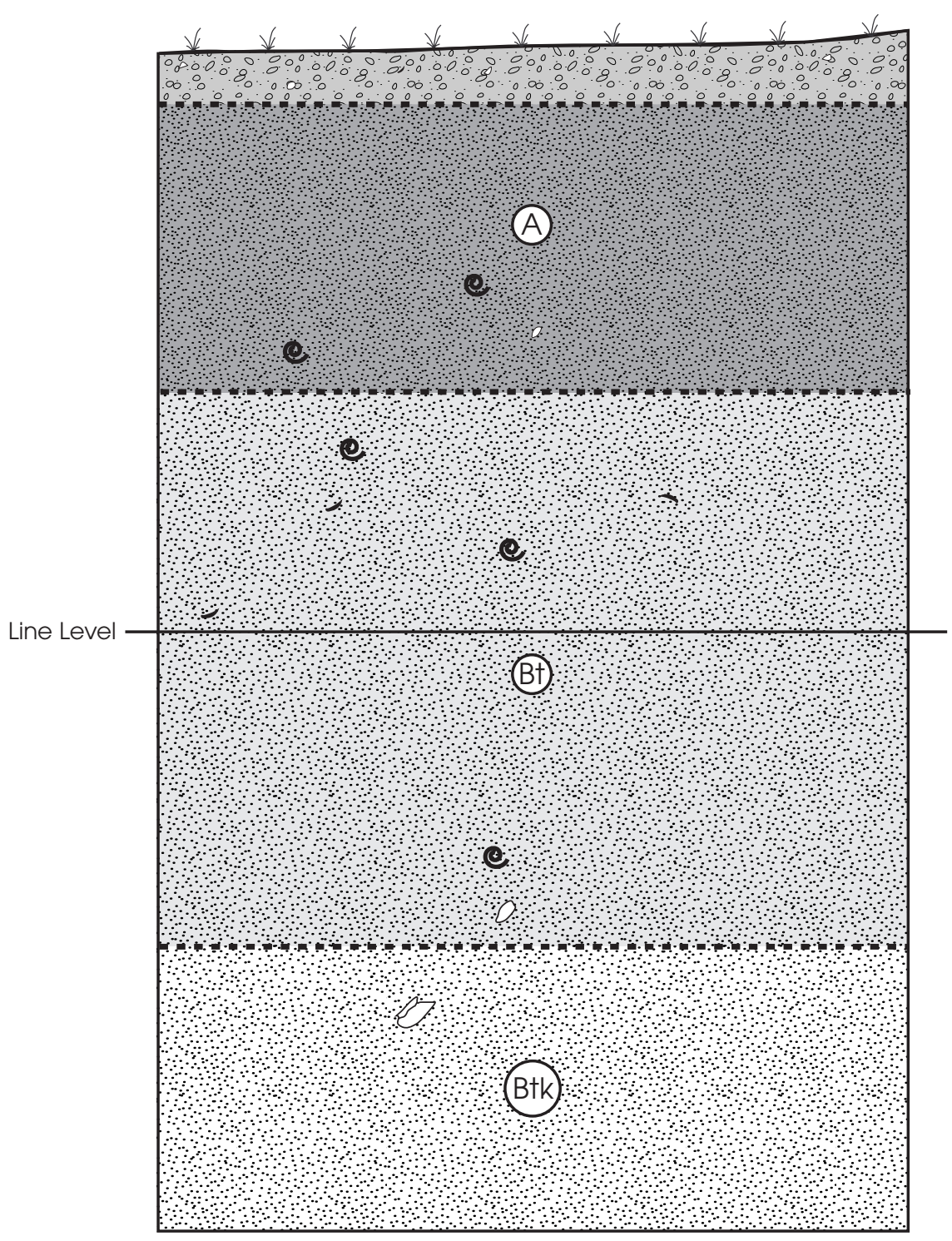

LE G N D

20.9 Sandy Silty Clay with Small Gravel

Sandy Silt Clay Very Dark Gray

$\because$ Sandy Silty Clay Dark Grayish Brown

Sandy Silty Clay with Abundant Carbonates

Burned Rock

(e) Gastropod

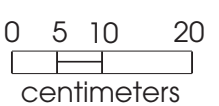

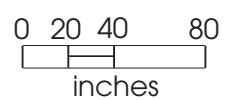

- Flake

Figure 4.1. Stratigraphic profile of Test Unit 2, east wall. 
National Register Testing at 41CV1636

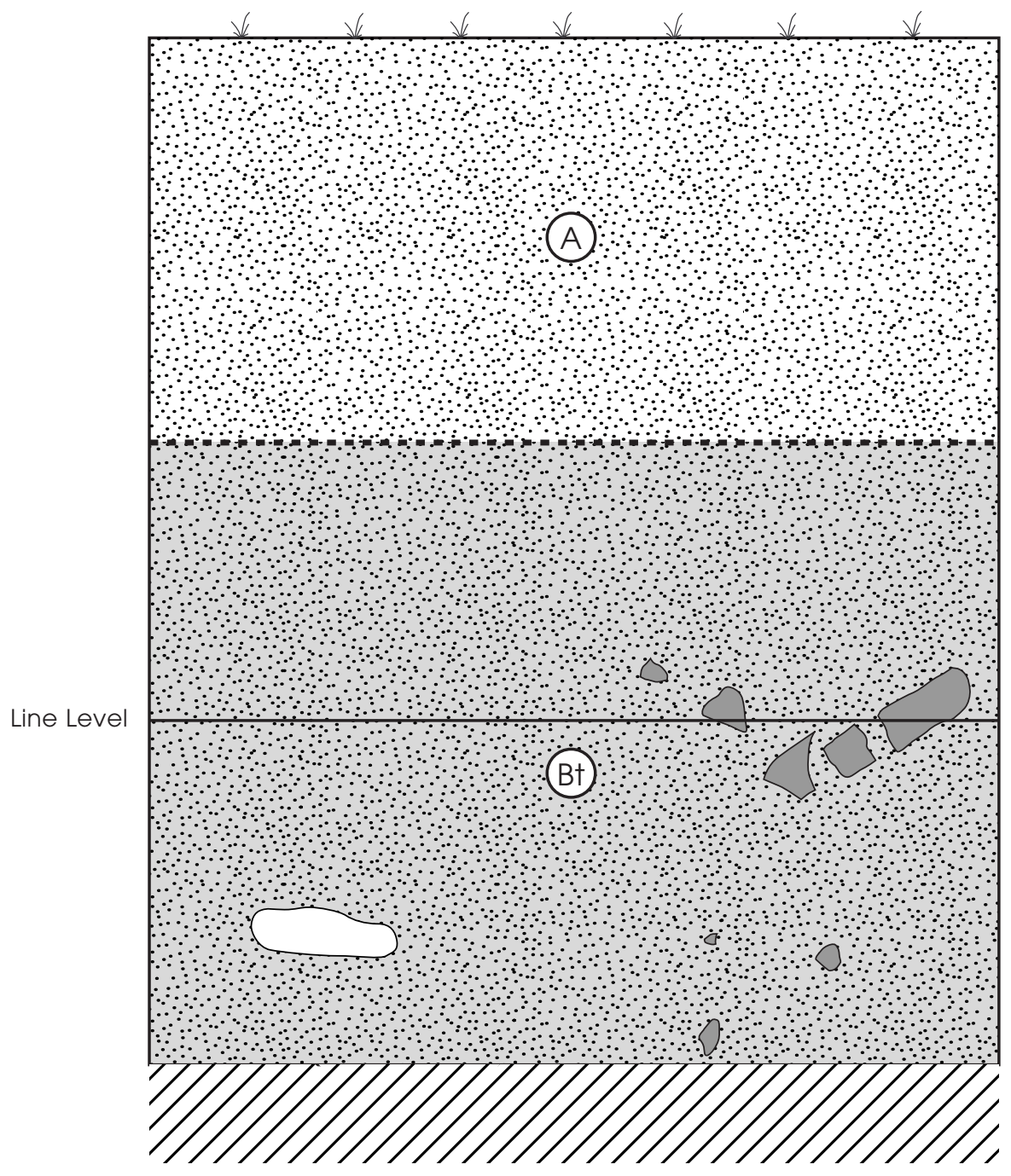

LE GEN D

$\begin{array}{ll}0 & \text { Burned Rock } \\ \text { Unburned Rock } \\ \cdots & \text { Silty Clay } \\ \cdots & \text { Silty Clay with Abundant Carbonates }\end{array}$

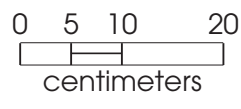

$0 \quad 2 \quad 4 \quad 8$
$\square$ inches

Figure 4.2. Stratigraphic profile of Test Unit 1, south wall. 


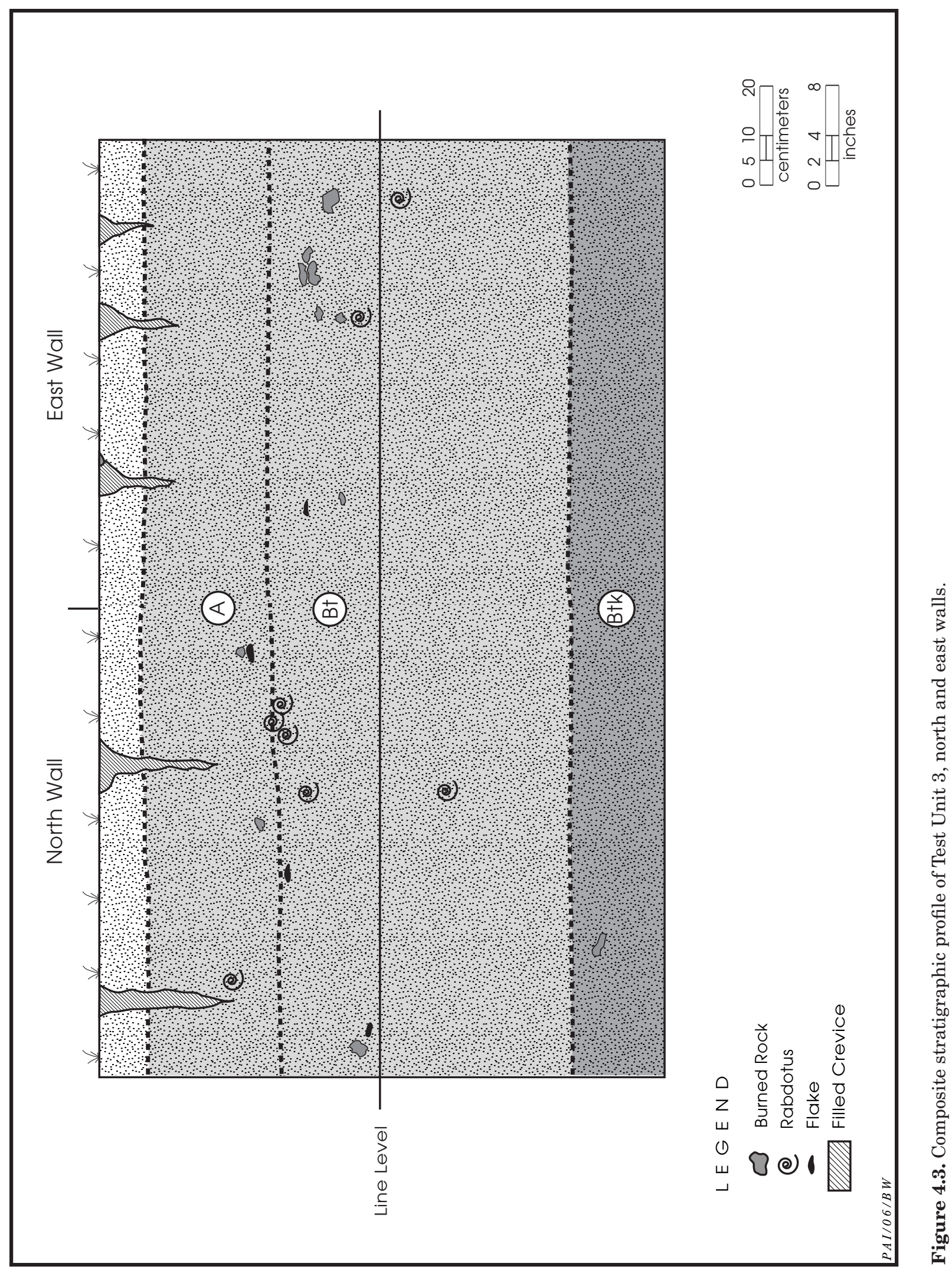




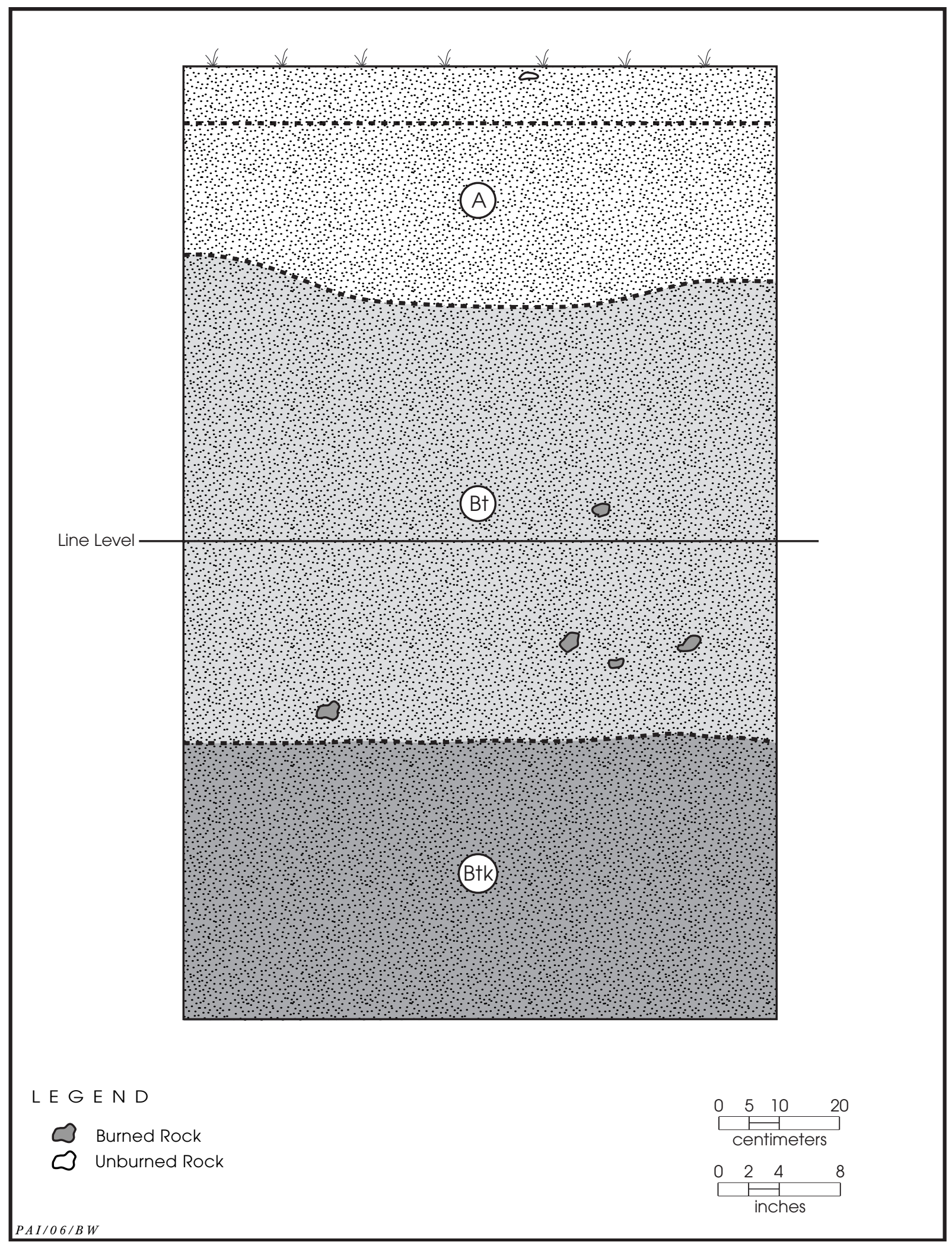

Figure 4.4. Stratigraphic profile of Test Unit 4, east wall. 


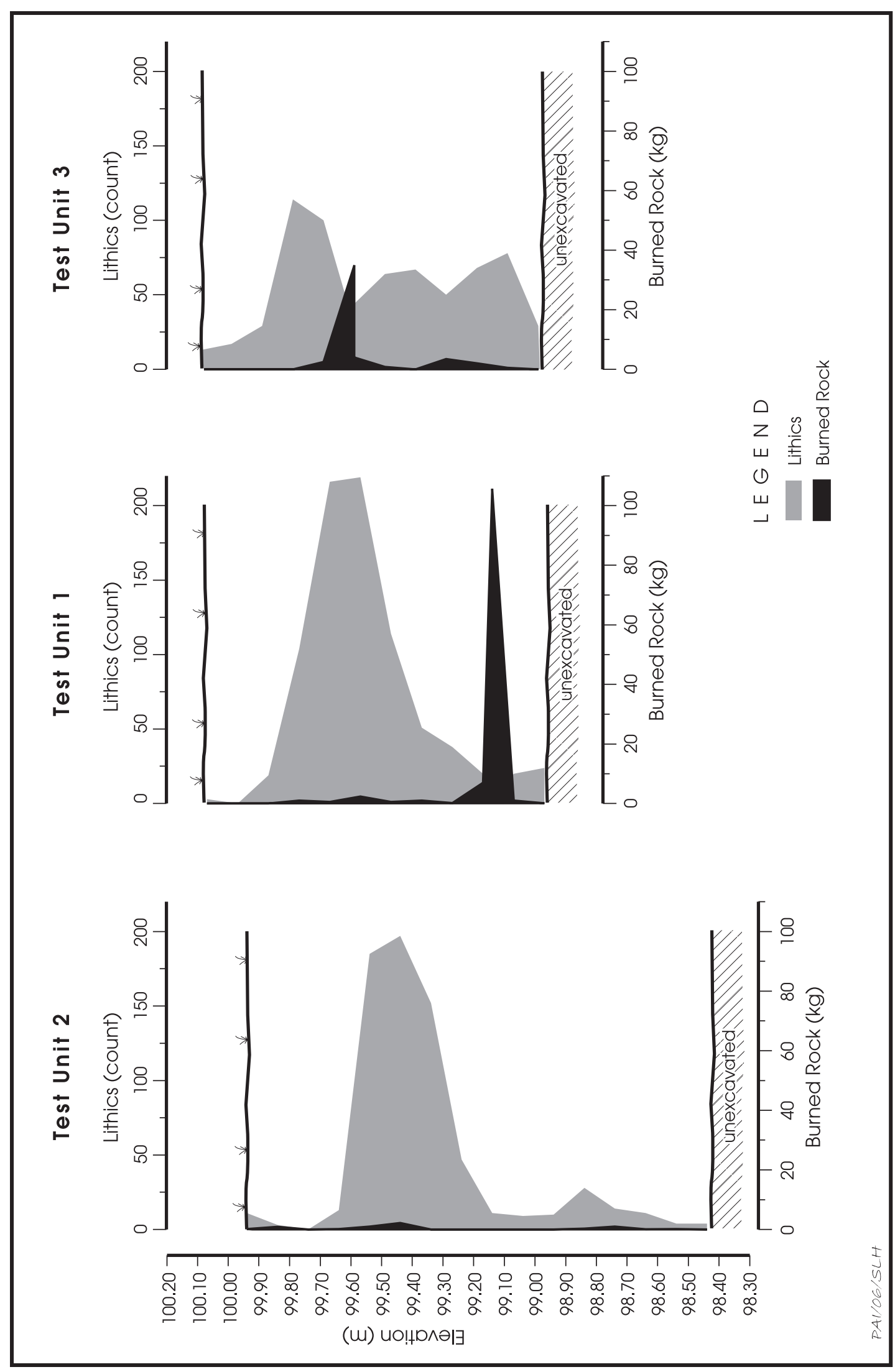

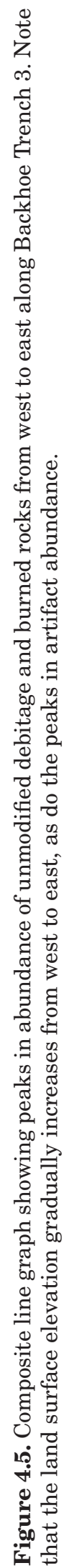


and cultural materials decreased significantly across the site from west to east. Two peaks are obvious in the vertical distribution of artifacts, debitage, and burned rocks, but these peaks become less obvious when considering the low densities of recovered faunal remains. The most notable peak occurs between Levels 3 and 7, with the second peak generally occurring between
Levels 10 and 14, depending on the excavation unit. Peak abundance of material culture in Test Units 1, 2, and 3 generally correspond to the increasing slope of the ground surface from west to east (Figure 4.5). The lithic assemblage recovered from Test Unit 4 is too small to derive meaningful statements regarding vertical distribution. 


\section{RESULTS OF INVESTIGATIONS: ANALYSIS OF FEATURES AND RECOVERED CULTURAL MATERIALS}

\section{5}

\begin{abstract}
Cultural materials recovered during National Register of Historic Places (NRHP) test excavations at 41CV1636 consist of an assemblage of chipped stone tools, lithic debris, burned rocks, Rabdotus sp. snails, a small number of comminuted and poorly preserved faunal remains $(n=159)$, and mussel shell umbos or hinge teeth $(\mathrm{n}=18)$. The most abundant artifact category recovered was chipped stone, totaling 2,342 pieces (including unmodified debitage). Table 5.1 provides counts and densities of all recovered materials from 41CV1636. Table 5.2 provides a summary of material recovered from a series of flotation samples from Features 1, 2 and nonfeature contexts. Materials recovered from flotation are discussed below.

Certain characteristics of data recovered from Features 1 and 2 point to different functions or purposes for each feature. Differences in construction and feature shape indicate that Feature 1 is a somewhat disturbed slab-lined, basin-shaped hearth. Feature 2 construction is typical of amorphous concentrations of large and small angular limestone and cobbles. There is less burned rock (in total $\mathrm{kg}$ ) in Feature 1 than in Feature 2. Burned rocks of Feature 2 include a greater proportion of small size fragments than Feature 1, resulting from more intensive burning or heating of rock material and successive intervals of heating and cooling. The presence of more identifiable microdebitage and small angular bone splinters in Feature 1 is characteristic of intact or relatively intact hearth or cooking features versus what might be predicted at secondary deposits of used or stockpiled burned limestone. Feature 2 may represent a secondary deposit of previously used and exhausted limestone from other
\end{abstract}

dismantled or abandoned hearth or cooking features at 41CV1636.

Two features were exposed and excavated between 99.64 and $99.09 \mathrm{~m}$ elevation. Charcoal within these features was minimal, but two very small samples were recovered in situ from Feature 2 in Test Unit 1. Feature matrix was collected in bulk from both features for flotation. Two small fragments of charcoal were recovered from Feature 2 flotation.

\section{FEATURE 1}

Feature 1, a burned rock concentration composed of angular and tabular burned rocks arranged in a basin shape, is located in Test Unit 3 between 99.64 and $99.55 \mathrm{~m}$ (Figure 5.1). Maximum excavated dimensions are $84 \mathrm{~cm}$ north-south by $88 \mathrm{~cm}$ east-west. After rocks were removed, the pit depth was measured as $9 \mathrm{~cm}$. The western half of the feature was collected as a flotation sample, and the eastern half was water-screened. Fill among the rocks resembles the surrounding nonfeature fill of silty clay loam and includes occasional dispersed chert flakes and Rabdotus sp. shells that are not related to feature function. No charcoal staining or oxidized sediment was observed. Rocks are not tightly clustered. The majority of the feature rock is moderately fractured, although some fragmented specimens are articulated. Some of the tabular pieces slope gently toward the center of the feature as they line the sloping sides of the pit (Figure 5.2). The limestone includes both tabular and angular/subangular weathered fragments. Some pieces exhibit fractures along internal bedding planes or joints. The majority of the rocks are between 0 and $5 \mathrm{~cm}(\mathrm{n}=235$, 


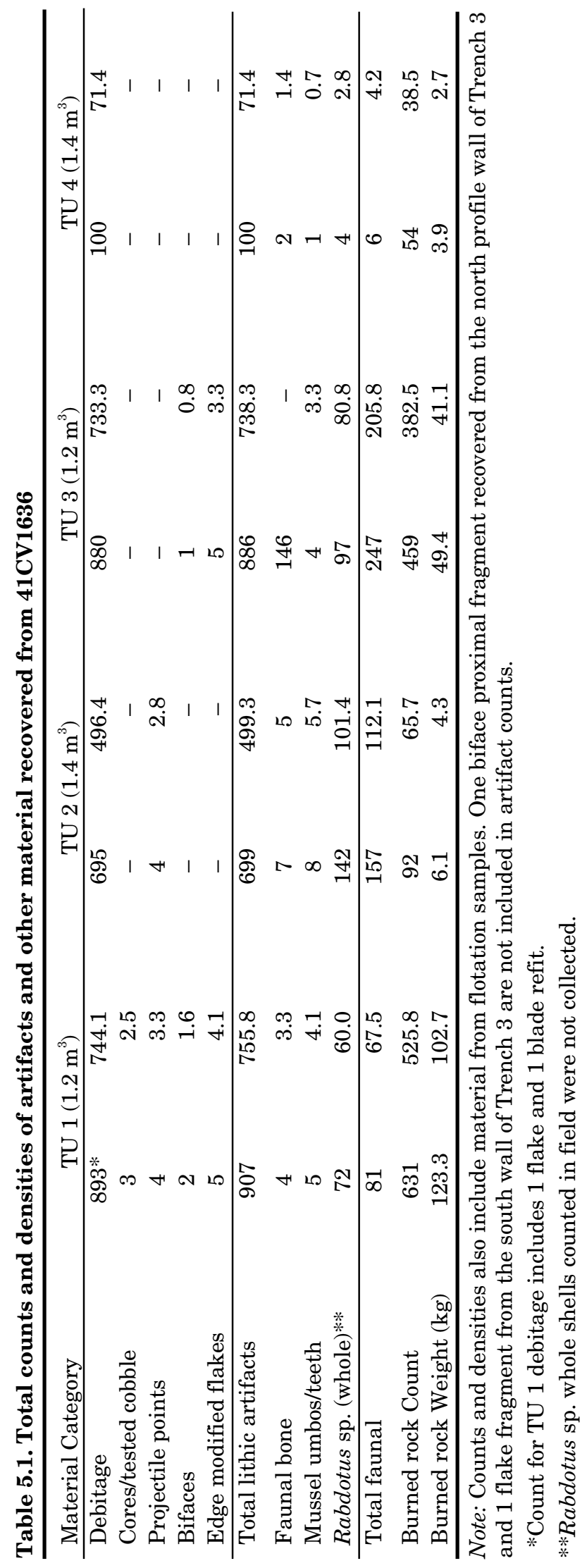


Table 5.2. Total counts and weights of artifacts recovered from flotation samples

\begin{tabular}{|c|c|c|c|c|c|c|c|c|}
\hline $\begin{array}{l}\text { Test } \\
\text { Unit }\end{array}$ & Level & Feature & $\begin{array}{l}\text { Depth } \\
(\mathrm{cmbs})\end{array}$ & Elevation & $\begin{array}{l}\text { Flotation } \\
\text { Sample \# }\end{array}$ & Material & $\#$ & $\begin{array}{c}\text { Weight } \\
(\mathrm{kg})\end{array}$ \\
\hline 1 & 9 & none & $80-90$ & $99.32-99.22$ & 5 & bone & 2 & - \\
\hline 1 & 9 & none & $80-90$ & $99.32-99.22$ & 5 & burned rock & 9 & $<0.1$ \\
\hline 1 & 9 & none & $80-90$ & $99.32-99.22$ & 5 & unmodified debitage & 27 & - \\
\hline 1 & & 2 (west $1 / 2$ ) & $83-99$ & $99.29-99.17$ & 6 & burned rock & 48 & 0.5 \\
\hline 1 & & 2 (west $1 / 2)$ & $83-99$ & $99.29-99.17$ & 6 & Rabdotus sp. & 3 & - \\
\hline 1 & & 2 (west $1 / 2)$ & $83-99$ & $99.29-99.17$ & 6 & unmodified debitage & 7 & - \\
\hline 1 & 9 and 10 & 2 (east $1 / 2)$ & $83-103$ & $99.29-99.09$ & 7 & burned rock & 155 & 3 \\
\hline 1 & 9 and 10 & 2 (east $1 / 2)$ & $83-103$ & 99.29-99.09 & 7 & Rabdotus sp. & 4 & - \\
\hline 1 & 9 and 10 & 2 (east $1 / 2)$ & $83-103$ & 99.29-99.09 & 7 & unmodified debitage & 13 & - \\
\hline 1 & 11 & none & $100-110$ & $99.12-99.02$ & 8 & burned rock & 9 & $<0.1$ \\
\hline 1 & 11 & none & $100-110$ & 99.12-99.02 & 8 & Rabdotus sp. & 2 & - \\
\hline 1 & 11 & none & $100-110$ & $99.12-99.02$ & 8 & unmodified debitage & 29 & - \\
\hline 3 & 6 & 1 (west $1 / 2$ ) & $50-59$ & $99.64-99.55$ & 1 & bone & 16 & - \\
\hline 3 & 6 & 1 (west $1 / 2$ ) & $50-59$ & $99.64-99.55$ & 1 & burned rock & 77 & 0.9 \\
\hline 3 & 6 & 1 (west $1 / 2$ ) & $50-59$ & 99.64-99.55 & 1 & unmodified debitage & 88 & - \\
\hline 3 & 7 & none & $60-70$ & $99.54-99.44$ & 2 & bone & 3 & - \\
\hline 3 & 7 & none & $60-70$ & 99.54-99.44 & 2 & burned rock & 8 & $<0.1$ \\
\hline 3 & 7 & none & $60-70$ & $99.54-99.44$ & 2 & Rabdotus sp. & 5 & - \\
\hline 3 & 7 & none & $60-70$ & $99.54-99.44$ & 2 & unmodified debitage & 56 & - \\
\hline 3 & 8 & none & $70-80$ & $99.44-99.34$ & 3 & burned rock & 8 & $<0.1$ \\
\hline 3 & 9 & none & $80-90$ & $99.34-99.24$ & 4 & bone & 79 & - \\
\hline 3 & 9 & none & $80-90$ & 99.34-99.24 & 4 & burned rock & 4 & $<0.1$ \\
\hline 3 & 9 & none & $80-90$ & 99.34-99.24 & 4 & Rabdotus sp. & 3 & - \\
\hline 3 & 9 & none & $80-90$ & 99.34-99.24 & 4 & unmodified debitage & 30 & - \\
\hline
\end{tabular}

71 percent) followed by the $5-10$-cm size grade ( $n=93,28$ percent). The base of the pit is concave with gently sloping sides. The feature is roughly oval shaped and is wider at the southern end. A portion of the pit appears to extend into the east wall of the unit. As the rocks were exposed during excavation, some stones were observed at vertical and other angles of repose, suggesting that after use the basin contents were disturbed, perhaps from rock recycling for other hearth features or removal of other contents. Also, because the entire basin is not completely lined with slabs, it is possible that the feature may have been partially cleaned out or otherwise disturbed. Rocks in excess of $10 \mathrm{~cm}$ in maximum dimension are notably absent from this feature, with the exception of one rock between 10 and $20 \mathrm{~cm}$. This also suggests that some of the rocks may have been removed or otherwise recycled into other features.

Material recovered from a flotation sample collected from the western half of the feature consists of 77 pieces of additional burned rock, 88 pieces of unmodified microdebitage, and 16 small burned and unburned fragments of unidentifiable bone. Virtually all of the microdebitage consists of small pressure flakes and fragments from tool retouch and resharpening activities. Table 5.3 provides summary data of burned rocks and other materials recovered from Feature 1.

\section{FEATURE 2}

Feature 2 is located in Test Unit 1 between 99.29 and $99.09 \mathrm{~m}$. The feature consists of a dense cluster of burned rocks first observed during the excavation of Trench 3 (Figure 5.3). The backhoe scraped through a section of burned rocks ca. $90 \mathrm{~cm}$ long by $90 \mathrm{~cm}$ wide. The feature was observed to continue into the south wall profile of Trench 3. Remnant feature dimensions after exposure of burned rocks were $98 \mathrm{~cm}$ north-south and $1 \mathrm{~m}$ east-west. In profile 


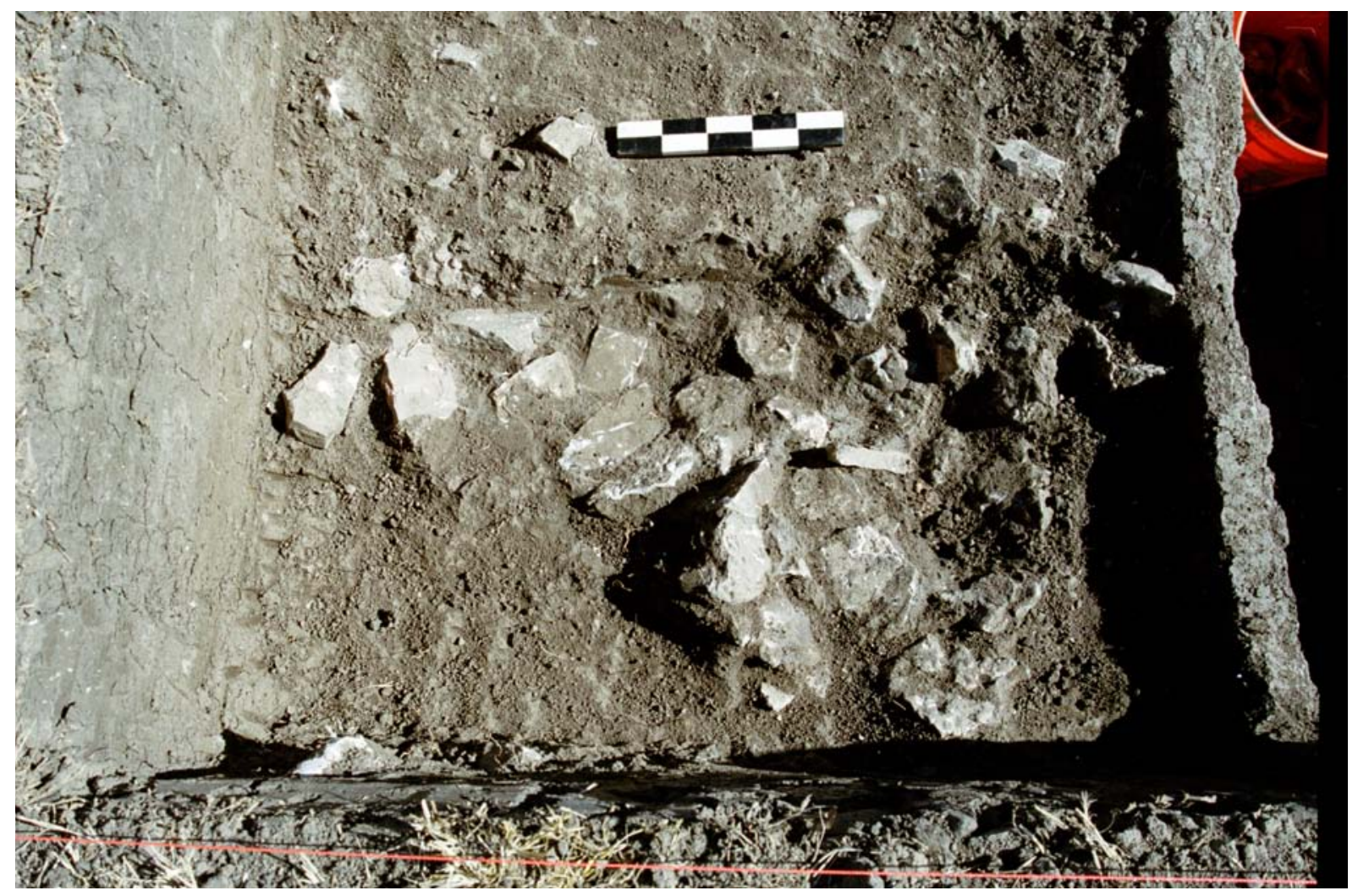

Figure 5.1. Limestone slab fragments line the base of Feature 1, a concentration of burned rocks. The western half of the feature was collected as a flotation sample.

in the south wall of the trench, the feature appears flat or slightly convex. There are one to four courses of burned rocks, and the feature is generally thicker in the central portion of Test Unit 1, tapering to the east and west and generally sloping downward from south to north. Overall, the feature presents a fairly dense concentration of cobbles, cobble fragments, and angular limestone (Figure 5.4). The feature and nonfeature soils were similar in character. The rocks are mostly angular and subangular chunks of limestone burned to a blue-gray with various shades of red and orange. Some fractures among the rock concentration were articulated. Some rock clasts had been so heavily burned that they literally disintegrated while they were being excavated. Numerous tabular pieces were noted, especially near the bottom of the feature. The majority of the rocks recovered from Feature 2 was between 0 and $5 \mathrm{~cm}(\mathrm{n}=283,63$ percent $)$, followed by $5-10 \mathrm{~cm}(\mathrm{n}=131,29$ percent $)$, then by rock fragments between 10 and $20 \mathrm{~cm}$ (35, 8 percent). Two charcoal samples were collected from the western side of the feature from beneath the middle courses of burned rocks. Sample C-1 was collected at $99.21 \mathrm{~m}$ (91 cm below surface), and C-2 was collected at $99.22 \mathrm{~m}$ (90 $\mathrm{cm}$ below surface). The feature was bisected during excavation, and the east half was collected as a flotation sample. Materials recovered from flotation samples consist of 20 pieces of unmodified debitage, 7 whole Rabdotus sp. shells, and 203 additional pieces of burned rock. Table 5.4 provides summary data of burned rock and other materials recovered from Feature 2. 

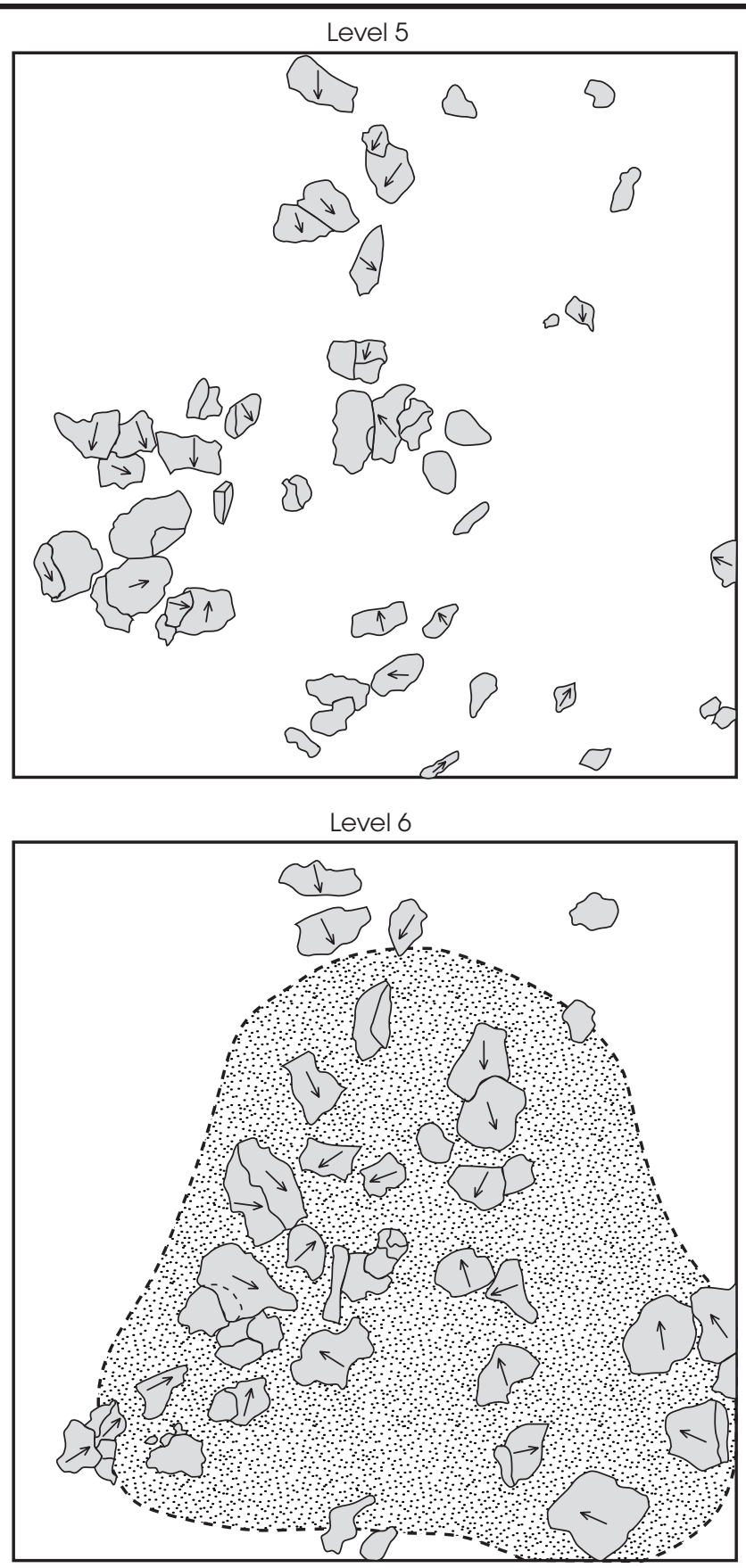

$L E G E N D$

$\circlearrowleft$ Burned Rock

.... Feature 1

$\rightarrow$ Angle of Slope

$P A I / 06 / B W$

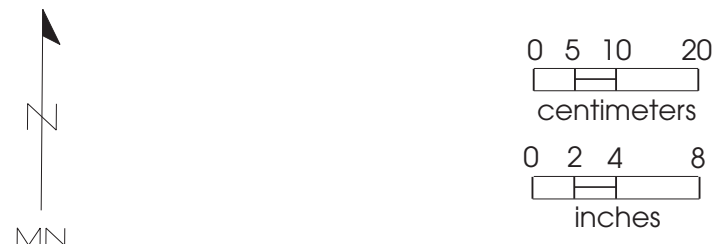

Figure 5.2. Planviews of Feature 1 shows rocks exposed in Levels 5 and 6. Arrows indicate whether the rocks are horizontal or tilted at various angles. 
Table 5.3. Summary of burned rocks and other materials from Feature 1

\begin{tabular}{lcc}
\hline Size $(\mathrm{cm})$ & $\#$ & Weight $(\mathrm{kg})$ \\
\hline $0-5$ & 235 & 3.9 \\
$5-10$ & 93 & 18.4 \\
$10-20$ & 1 & 1 \\
\hline Total & $329^{*}$ & $23.3^{*}$ \\
\hline
\end{tabular}

*Includes burned rock recovered from flotation sample 1.

Materials recovered from flotation sample 1, western $1 / 2$ of Feature 1

\begin{tabular}{lcc}
\hline Material & $\#$ & Weight $(\mathrm{kg})$ \\
\hline Unmodified debitage & 88 & - \\
Bone & 16 & - \\
Burned rock & 77 & 0.9 \\
\hline
\end{tabular}

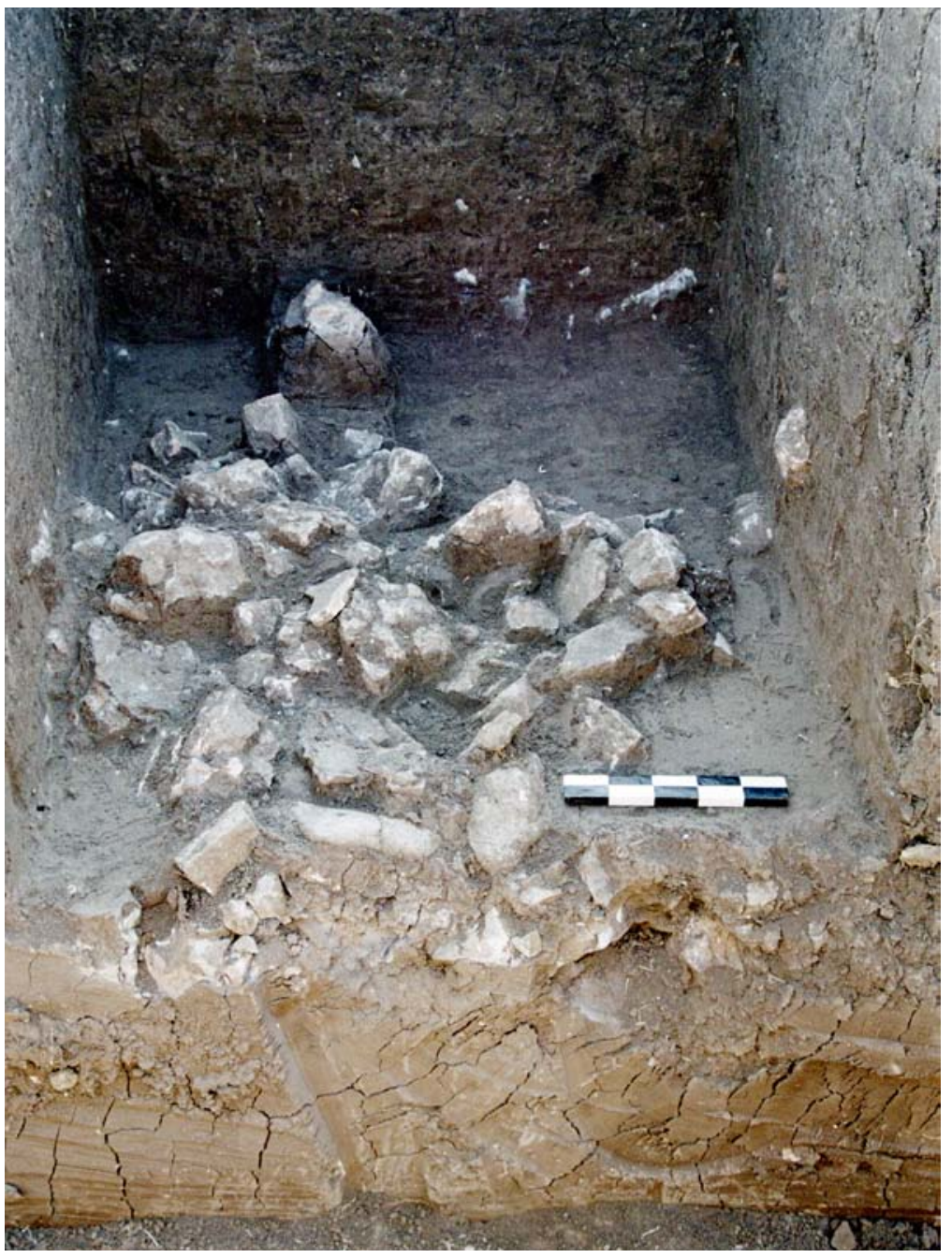

Figure 5.3. Photograph of Feature 2, a burned rock cluster. 


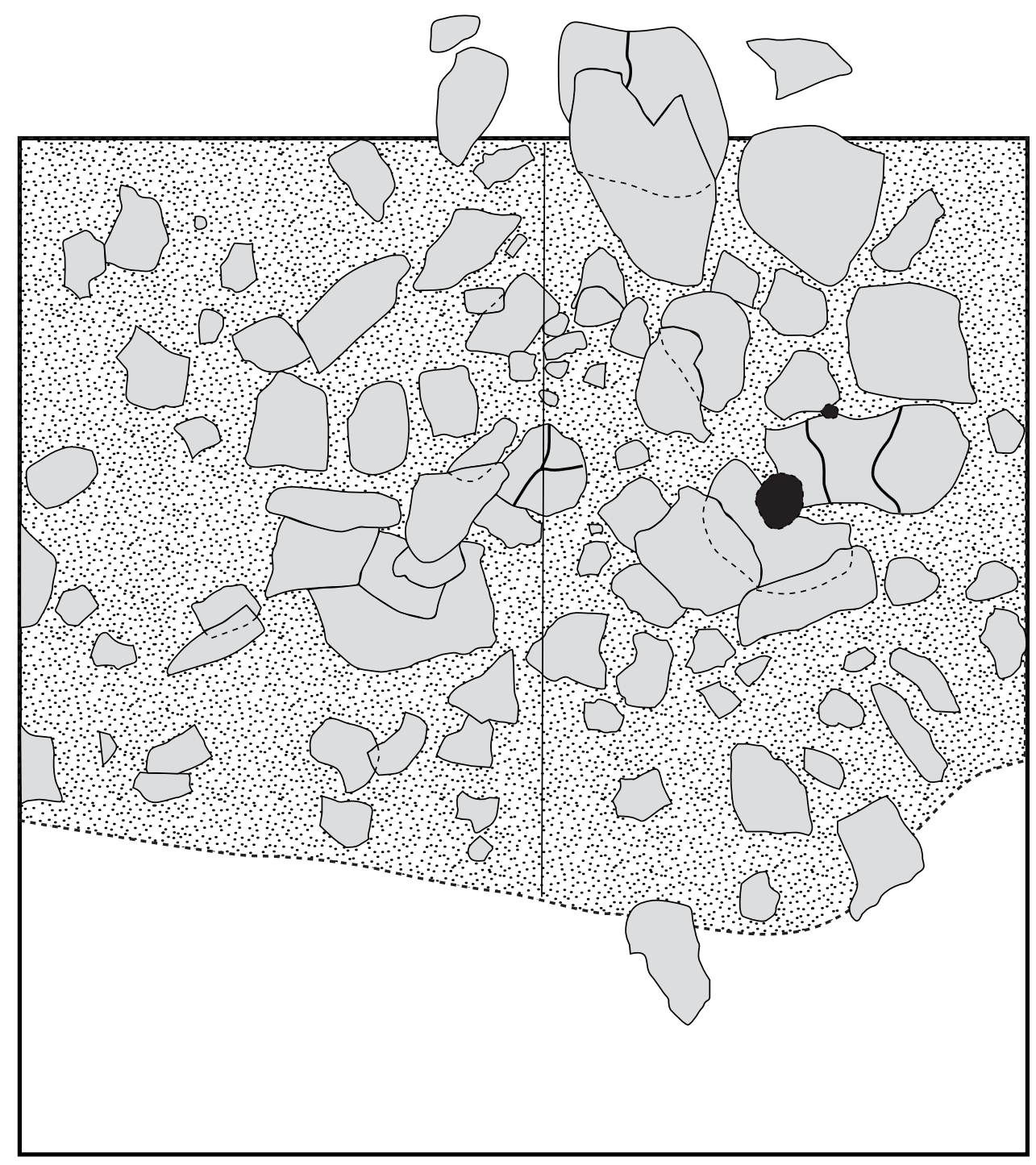

$L E G E N D$

๑) Burned Rock

$1 . .3$ Feature 2

- Area of scattered charcoal

PAI/06/BW
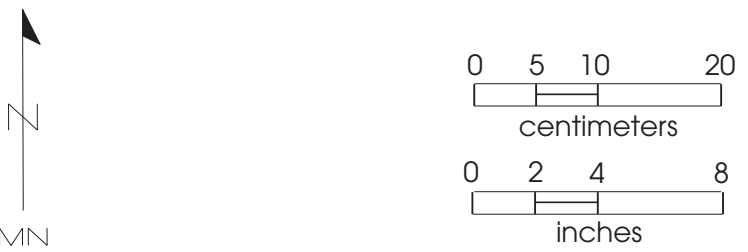

Figure 5.4. Planview of Feature 2. 
Table 5.4. Summary of burned rocks and other materials from Feature 2

\begin{tabular}{lcc}
\hline Size $(\mathrm{cm})$ & $\#$ & Weight $(\mathrm{kg})$ \\
\hline $0-5$ & 283 & 16.1 \\
$5-10$ & 131 & 44.9 \\
$10-20$ & 35 & 39.4 \\
\hline Total & $449^{*}$ & $100.4^{*}$ \\
\hline
\end{tabular}

*Includes burned rock recovered from flotation samples 6 and 7.

Material recovered only from flotation samples 6 (west) and 7 (east) of Feature 2

\begin{tabular}{lccc}
\hline & $\begin{array}{c}\text { West } \\
1 / 2\end{array}$ & $\begin{array}{c}\text { East } \\
1 / 2\end{array}$ & \\
\cline { 2 - 3 } Material & $\#$ & $\#$ & Total \\
\hline Unmodified debitage & 7 & 13 & 20 \\
Rabdotus sp. & 3 & 4 & 7 \\
Bone & - & - & - \\
Burned rock & 48 & 155 & 203 \\
\hline
\end{tabular}

\section{ANALYSIS OF CULTURAL MATERIALS RECOVERED}

\section{Chipped Stone Artifacts}

The chipped stone assemblage from test excavations consists of 8 dart points or dart point fragments, 3 biface fragments, 4 retouched flakes or fragments, and 6 utilized flakes or fragments. A tested cobble and 2 cores were also recovered. Unmodified debitage consists of 2,568 pieces. Each artifact group is described in greater detail below.

\section{Dart Points}

The eight recovered projectile points represent complete, fragmentary, and reworked examples of four Pedernales dart points or probable Pedernales points, one extensively reworked Provisional Type 1 point, one probable Provisional Type 1 stem, one impact-damaged untyped dart point blade, and one untyped dart point distal fragment (Figure 5.5). Each specimen is described below in more detail. One heavily burned point and small distal fragment are not depicted in Figure 5.5.

\section{Provisional Type 1}

Provisional Type 1 points are represented by two fragmentary specimens. These specimens are tentatively identified as Provisional Type 1 because they do not completely conform to the original type description of Bulverde as provided by Suhm and Jelks (1962). During previous shovel testing and survey work at the site (McWilliams 2005), the first Provisional Type 1 point was recovered from backdirt associated with Trench 3. This specimen exhibited a narrow, rectangular stem similar in dimension to the examples recovered during current test excavations.

The first specimen recovered during testing (Figure 5.5a) is a heavily reworked example with a complete stem recovered from Level 11, Test Unit 2, at $98.99-98.89 \mathrm{~m} \mathrm{(100-110} \mathrm{cm} \mathrm{below}$ surface). A small portion of one lateral edge and shoulder retains remnants of a previous impact scar. Lateral blade edges and tip are blunted from use and resharpening and are heavily step-fractured. Lateral stem edges are straight-contracting, and the basal edge is slightly concave. Stem edges are very wellflaked, and the stem overall has a well-defined wedge shape. Raw material is a medium gray to 


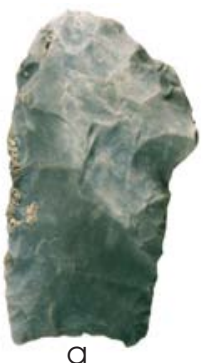

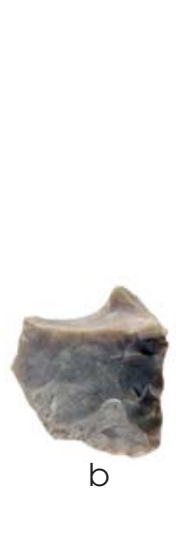
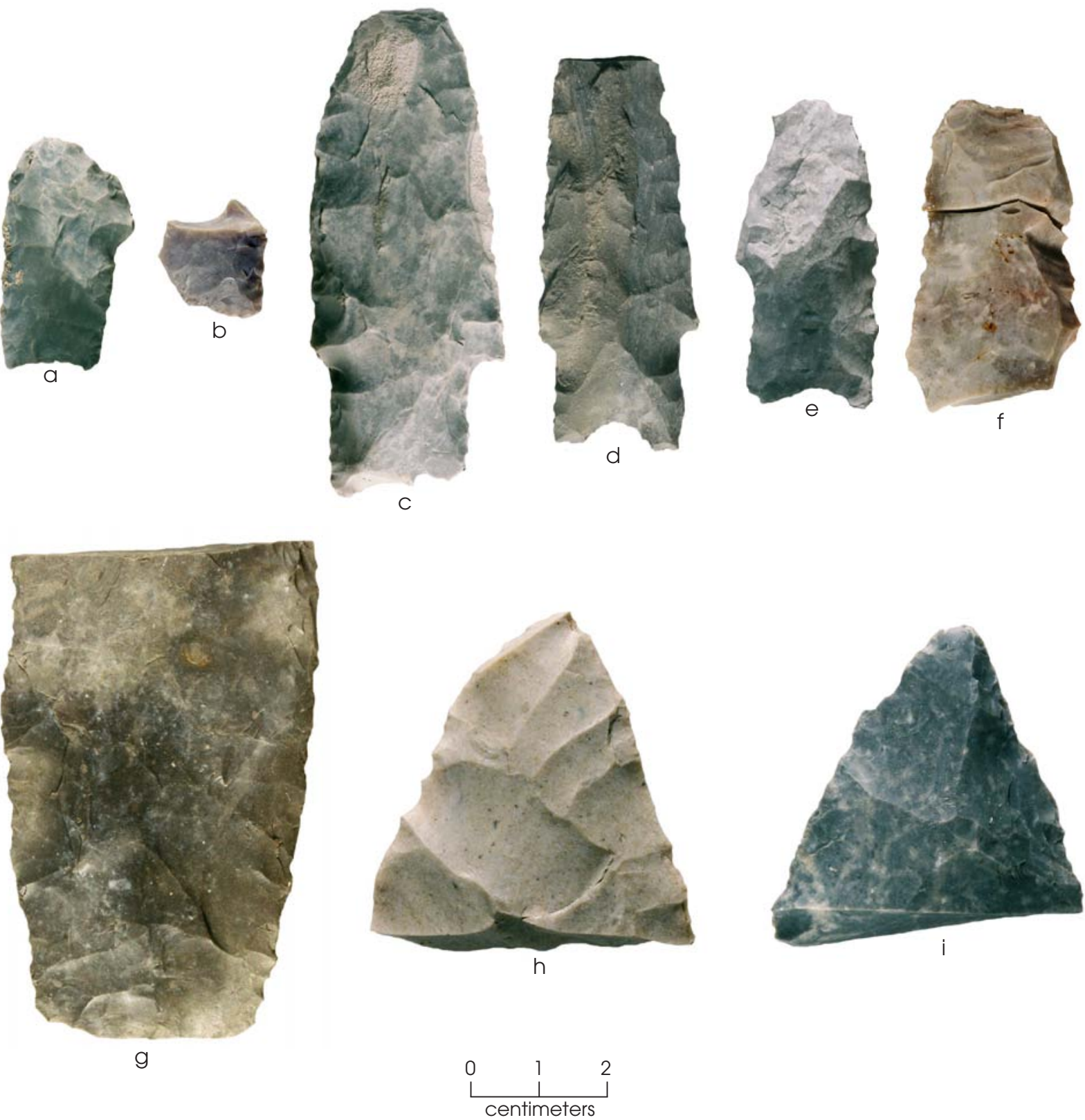

g

Figure 5.5. Dart points and bifaces. (a, b) Provisional Type I; (c-e) Pedernales; (f) untyped blade fragment with impact fracture, $(\mathrm{g})$ finished knife fragment; $(\mathrm{h}-\mathrm{i})$ middle stage distal biface fragments.

white mottled fine-grained chert. Dimensions for this specimen are: maximum length $32.45 \mathrm{~mm}$; stem length $18.72 \mathrm{~mm}$; stem thickness $6.94 \mathrm{~mm}$; juncture width $16.09 \mathrm{~mm}$; basal width 13.63 ; basal concavity depth $1.83 \mathrm{~mm}$; weight $5.4 \mathrm{~g}$.

The second Provisional Type 1 specimen (Figure 5.5b) is a small stem fragment recovered from Level 7, Test Unit 1, between 99.52 and $99.42 \mathrm{~m} \mathrm{(60-70} \mathrm{cm}$ below surface). The nature of the bending fracture at the juncture suggests breakage of the point in the haft during impact. One lateral ear or stem corner has been snapped off obliquely, and one edge of the bending fracture has multiple small-step fractures. The 
stem is wedge-shaped, with a slightly concave basal edge. Raw material is a fine-grained medium gray chert with no flecking. Stem width is $15.84 \mathrm{~mm}$, and stem thickness is $6.07 \mathrm{~mm}$.

The single Provisional Type 1 point recovered during initial site survey and the two later examples recovered during the current NRHP excavations at 41 CV1636 very closely conform to the morphology of Provisional Type 1 points found at Fort Hood (Kleinbach et al. 1999:338344). All three have narrow, rectangular stems virtually identical to recovered specimens from dated contexts at 41CV1235 located on Fort Hood (Kleinbach et al. 1999). Stem and base measurements of specimens from 41CV1636 fall within the range of variability of 11 specimens recovered from 41CV1235 (Kleinbach and Boyd 1999:335). Other similar points have been recovered from the Youngsport (Shafer 1963), Evoe Terrace, and Landslide sites (Sorrow et al. 1967). These points also show some morphological affinities to such point types as Carrollton, Nolan, or Travis but are distinct in stem morphology from these types.

\section{Pedernales}

A series of four incomplete and relatively complete Pedernales points were recovered during excavations from proveniences stratigraphically above the Provisional Type 1 specimens. Combined with three previously recovered Pedernales points during shovel testing and survey work at 41CV1636, the total number of points of this type from the site is 7 . Only those recovered during the current NRHP excavations are discussed below.

Two relatively complete Pedernales points were recovered from Test Unit 2, Levels 6 and 10. The first specimen (Figure 5.5c) was obtained from Level 6 between 99.49 and $99.39 \mathrm{~m}$ (50$60 \mathrm{~cm}$ below surface). It is relatively complete, with distal crushing and step/hinge fractures at the tip due to impact. One slight and one prominent shoulder are present. Lateral blade edges are slightly convex and exhibit uniform bifacial flaking. Resharpening is only evident approximately $1 \mathrm{~cm}$ back from the tip on each lateral edge and gives the tip area a beveled appearance. Stem edges are straight and parallel, and the basal edge is concave. One ear of the base has a postdepositional break. Raw material is a fine-grained, moderately patinated, medium gray chert with two white chalky inclusions similar to cortex, one near the tip and one along a blade edge. This dart point is similar to Pedernales Variety 3 (Goode 2002:55-56) except the stem may be bit wider. It is unclear whether this material is represented in the unmodified debitage. Dimensions are: length $72.75 \mathrm{~mm}$; blade length $52.75 \mathrm{~mm}$; blade width $27.30 \mathrm{~mm}$; blade thickness $8.73 \mathrm{~mm}$; stem length $20.00 \mathrm{~mm}$; stem thickness $8.71 \mathrm{~mm}$; juncture width $21.52 \mathrm{~mm}$; basal width $20.35 \mathrm{~mm}$; basal thickness $4.79 \mathrm{~mm}$; weight $20.6 \mathrm{~g}$.

The second relatively complete specimen from Test Unit 2 (Figure 5.5d) was recovered from Level 10 between 99.09 and $98.99 \mathrm{~m}$ (90-100 cm below surface). The tip of the blade is missing due to a postdepositional break, and one basal ear is missing and may have broken during use. The lateral blade edges are straight but have been reworked and are alternately beveled to the left, yielding a trapezoidal cross section to the blade. Stem edges are slightly convex, with a relatively deep basal concavity created by removal of a single flake from one surface. Stem edges are also ground smooth, and shoulders are present but not sharp. Raw material is chert. One side of the point is a fine-grained, medium gray chert and the other side grades into a light gray coarse chert that tends to yield step fractures. Thin banding is present throughout, and there is a slight patination on both faces. Unmodified debitage comparable to this material was not observed during analysis. This dart point is similar in form to Pedernales Variety 3 (Goode 2002:55-56) and is beveled similarly to a specimen recovered from Backhoe Trench 3 during the initial survey. Dimensions are: length $58.09 \mathrm{~mm}$; blade length $42.48 \mathrm{~mm}$; blade width $20.82 \mathrm{~mm}$; blade thickness $9.20 \mathrm{~mm}$; stem length $15.61 \mathrm{~mm}$; stem thickness $6.03 \mathrm{~mm}$; juncture width $18.50 \mathrm{~mm}$; basal width $18.42 \mathrm{~mm}$; basal thickness $3.41 \mathrm{~mm}$; weight $13.3 \mathrm{~g}$.

Two heavily burned Pedernales points that also resemble Pedernales Variety 3 from the Anthon site were recovered from Test Unit 1 . The first was recovered from Level 5 between 99.72 and $99.62 \mathrm{~m} \mathrm{(40-50} \mathrm{cm} \mathrm{below} \mathrm{surface).} \mathrm{Compris-}$ ing two fragments, this base/stem section has been significantly damaged by thermal fracture and potlid scars on both surfaces. Remaining stem edges are straight and slightly contracting. A single flake from each surface of the basal edge thinned the base and produced the concavity. One basal ear is pronounced and slightly 
inwardly curved, and the other is missing, probably due to impact of the basal edge against the foreshaft during use. Measurements are: stem length $22.40 \mathrm{~mm}$; juncture width $20.31 \mathrm{~mm}$; basal width $17.73 \mathrm{~mm}$. Because the fragments are heavily burned, the raw material could not be assigned to any known Fort Hood chert types or other known central Texas chert types.

The second burned specimen (Figure 5.5e) was recovered from Level 6 between 99.62 and $99.52 \mathrm{~m}$ (50-60 cm below surface). Although the stem is complete, both surfaces of the blade have multiple overlapping potlid scars that have removed much of the original flake surfaces. Stem edges are straight and slightly expanding with a concave basal edge. The basal concavity was created by multiple small flake removals on one face and one larger flake removal on the opposing face. One shoulder is present but is very slight. Measurements for this point fragment are: stem length $20.54 \mathrm{~mm}$; stem width $18.06 \mathrm{~mm}$; stem thickness $7.84 \mathrm{~mm}$; basal concavity depth $2.43 \mathrm{~mm}$. Burning precludes the formal identification of the chert type for this artifact.

In addition to these Pedernales specimens recovered during the current NRHP eligibility testing, initial site survey (McWilliams 2005) yielded three other Pedernales points. Two were recovered from general fill from Backhoe Trench 3 , and one was recovered from a shovel test between 40 and $60 \mathrm{~cm}$ below surface. Both specimens from Backhoe Trench 3 are complete, heavily patinated, and have been bifacially reworked on the distal end. These points are similar in morphology to Pedernales Variety 1 points from the Anthon site (Goode 2002:51-52). The point from the shovel test is also complete, but much thinner in cross section, has been resharpened distally by alternate beveling, and was manufactured of a light gray chert identified as Chert Type 1 for this study (see Raw Material Types below). In morphology, this point is closely similar to Pedernales Variety 3 (Goode 2002:55-56).

With the exception of two Pedernales points similar to Variety 1 (Goode 2002:51-52), the points all have relatively narrow stems with essentially straight edges and basal concavities. Complete specimens from 41CV1636 are lanceolate rather than triangular, with straight stems, which follows the general trend of Pedernales points in collections from Fort Hood (Callister et al. 1994:308-309). A similar trend in Pedernales point morphology was documented at 41MM340 on the Little River in Milam County (Tomka et al. 2003).

\section{Untypeable Dart Points}

Two projectile point fragments were recovered that could not be assigned to a known projectile point type. These fragments are assigned to a general projectile point category on the basis of technology and fracture patterns, suggesting that they represent fragments of these artifacts.

The first specimen is a small distal fragment recovered from Test Unit 1, Level 6, between 99.62 and $99.52 \mathrm{~m}(50-60 \mathrm{~cm}$ below surface). The piece has a diamond-shaped cross section and has been pressure flaked along the lateral edges and exhibits a bending fracture. Cross-section shape suggests it may be a distal fragment of a beveled or resharpened dart point or biface.

The second specimen (Figure 5.5f) is much of the blade portion refit from two fragments recovered from Test Unit 2, Level 2, between 99.89 and $99.79 \mathrm{~m} \mathrm{(10-20} \mathrm{cm}$ below surface). The fracture that separates the refit blade portion into two pieces is possibly postdepositional in origin. The refit blade exhibits three fractures associated with distal impact. The first fracture is a large macrobreak on one face of the point associated with crushing and collapse of the tip. The second is a lateral macrofracture that removed much of one lateral edge. This fracture type is not associated with removal of burin spalls. The third is a transverse break that snapped the blade from the stem portion. The remaining intact portion of one lateral edge is straight. Although the blade fragments are moderately patinated, a slight luster and blushes of pink on both surfaces suggest that the chert was heat treated prior to manufacture. Due to patination, it is not possible to assign this material to a known Fort Hood or Edwards Plateau chert type. Comparison of overall blade characteristics of this fragment with the projectile point sample suggest it may be a Pedernales blade fragment.

\section{Bifaces}

There are three fragmentary nonprojectile point bifaces recovered at 41CV1636 (Figure $5.5 \mathrm{~g}, \mathrm{~h}$, and i). Two are distal fragments, and one is a sizable proximo-medial fragment. The distal 
fragments can be considered as Stage II preform manufacturing failures (c.f. Frison and Bradley 1980:33), while the proximo-medial fragment may be a knife or very late-stage biface fragment. All are manufactured from chert and each is described separately below.

The first biface fragment is a large proximomedial portion of a very late stage rectangular knife or Stage III preform with a distal bending fracture. This fragment was recovered from the north wall of Backhoe Trench 3 at $99.40 \mathrm{~m}$. Lateral blade edges are straight to slightly convex and the basal edge is slightly convex, but there are defined corners between the base and lateral edges. The piece has been shaped by well-executed softhammer bifacial thinning and has a thin lenticular cross section. There is some minimal pressure flaking along the lateral edges and slight but noticeable bevels along the right edge of both faces. There are no traces of wear suggesting use or hafting, but there are patches of abrasion along the lateral edges characteristic of edge-grinding during platform preparation. Edge grinding may be associated with hafting. Some of the expanding flake scars on both surfaces are associated with quite small contact areas, suggesting that a percussor with a small contact area (possibly a punch) may have been used during final thinning and shaping. The raw material is a fine-grained, mottled light gray and medium gray chert with slight patina development. Scattered small white flecks or inclusions are visible in the chert, and the chert is similar to chert type 1 described below. The maximum length is $73.94 \mathrm{~mm}$, medial width $45.80 \mathrm{~mm}$, medial thickness $8.23 \mathrm{~mm}$, basal width $32.59 \mathrm{~mm}$, basal thickness $6.22 \mathrm{~mm}$, and fragment weight $38.7 \mathrm{~g}$.

This biface is similar in shape and technology to lanceolate bifaces commonly in association with Pedernales and other Late Archaic dart point styles. Weir illustrates identical bifacial knife forms associated with his Round Rock phase (Weir 1976:60). The fragment from 41CV1636 is also similar to the large Kinney biface preforms found in association with Late Archaic deposits containing Pedernales points at the Anthon site (41UV60) (Goode 2002:40-50).

A distal fragment of an unfinished Stage II biface preform was recovered from Test Unit 3, Level 5, between 99.74 and $99.64 \mathrm{~m}(40-50 \mathrm{~cm}$ below surface). The biface broke transversely along a fracture during flaking. One lateral edge is more sinuous and less refined in shape than the opposing edge. A mix of both hardhammer and softhammer percussion is evident along the lateral edges and faces, and the piece has a biconvex cross section. Pressure flaking is not present, although the right edge and face of one side has seen more softhammer flaking than the opposing edge and faces. Some grinding and slight smoothing associated with platform preparation is present along one lateral edge. The chert is an off-white or cream color with a light luster and may have been heat treated but is not identified as one of the seven chert types discussed below. Maximum thickness of this fragment is $11.90 \mathrm{~mm}$.

A second distal portion of a large Stage II bifacial preform was found in Test Unit 1, Level 6, between 99.62 and $99.52 \mathrm{~m}$ (50-60 cm below surface). This particular fragment is broken in a transverse oblique fracture. The fragment has a biconvex cross section. Both lateral edges are sinuous and reflect flaking by a mix of hardhammer and softhammer percussion. Some grinding and slight smoothing associated with platform preparation during manufacture is present, but there is no indication of tool use. Raw material is a medium gray chert with light gray mottling that may be a developing patina. It is tentatively identified as chert type 1 . Maximum thickness of this fragment is $11.91 \mathrm{~mm}$.

The width of each of these fragments is comparable to the more finished biface fragment recovered from the north wall of Trench 3 and may be early-stage fragments of similar lanceolate bifaces. The absence of earlier-stage preforms and fragments suggests that biface tool manufacture began with mid-stage preforms in which initial stages had been initiated elsewhere. The scarcity of cortex in the unmodified debitage supports this interpretation.

The complete absence of earlier stage bifaces or fragments is telling regarding probable tool kit composition of individuals and groups coming to the 41CV1636 locality. It strongly supports an inference that lithic procurement activities were not an important aspect of activities conducted onsite and that individuals were equipped with late-stage bifacial preforms as part of their personal gear.

\section{Edge-Modified Flakes}

Two categories of edge-modified flake tools were recovered during excavations: utilized 
flakes and retouched flakes. Utilized flake tools are unretouched flakes or fragments that were selected for and used as tools without deliberate modification and are identified by the presence of microscopic or macroscopic use-wear traces. Retouched flakes have at least a portion of one edge deliberately modified by retouch of some type. Six utilized and four retouched flakes and fragments were recovered during test excavations at 41CV1636. Most of these implements are small, like much of the unmodified flake debitage, which hints that the manufacture of these expedient artifacts was based on selection of suitable flakes and fragments from debitage produced at the site during manufacture of other formal implements. Dimensions of edge-modified flakes recovered during test excavations are provided in Table 5.5. Figure $5.6(\mathrm{a}-\mathrm{g})$ shows representative examples of utilized and retouched flake tools recovered from 41CV1636.
Table 5.5. Dimensions of edge-modified flakes recovered from $41 \mathrm{CV} 1636$

\begin{tabular}{lccccc}
\hline Lot \# & Type & $\begin{array}{c}\text { Length } \\
(\mathrm{mm})\end{array}$ & $\begin{array}{c}\text { Width } \\
(\mathrm{mm})\end{array}$ & $\begin{array}{c}\text { Thickness } \\
(\mathrm{mm})\end{array}$ & $\begin{array}{c}\text { Weight } \\
(\mathrm{g})\end{array}$ \\
\hline $14-2^{*}$ & Utilized & 39.03 & - & 3.58 & - \\
$14-3^{*}$ & Utilized & - & 24.21 & 6.86 & - \\
$41-1^{*}$ & Utilized & - & - & 4.94 & - \\
$42-1^{*}$ & Utilized & - & - & 6.54 & - \\
$43-1$ & Utilized & 54.29 & 37.40 & 21.82 & 32.4 \\
$47-1$ & Utilized & 38.49 & 18.67 & 4.77 & 3.0 \\
$14-1^{*}$ & Retouched & - & 32.10 & 7.69 & - \\
$14-4^{*}$ & Retouched & - & 24.79 & 5.01 & - \\
$16-1^{*}$ & Retouched & - & 35.28 & 15.45 & - \\
$43-2^{*}$ & Retouched & - & - & 9.93 & - \\
\hline
\end{tabular}

*Indicates a fragmentary specimen.
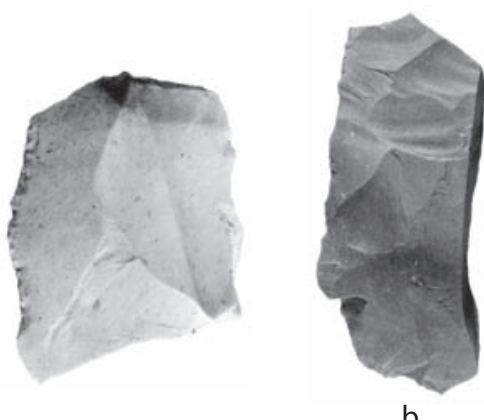

\section{Utilized Flakes}

Two flake fragments with traces of use wear were recovered from Test Unit 1, Level 8, between 99.42 and $99.32 \mathrm{~m}(70-80 \mathrm{~cm}$ below surface). The first artifact (Figure 5.6a), a proximal fragment
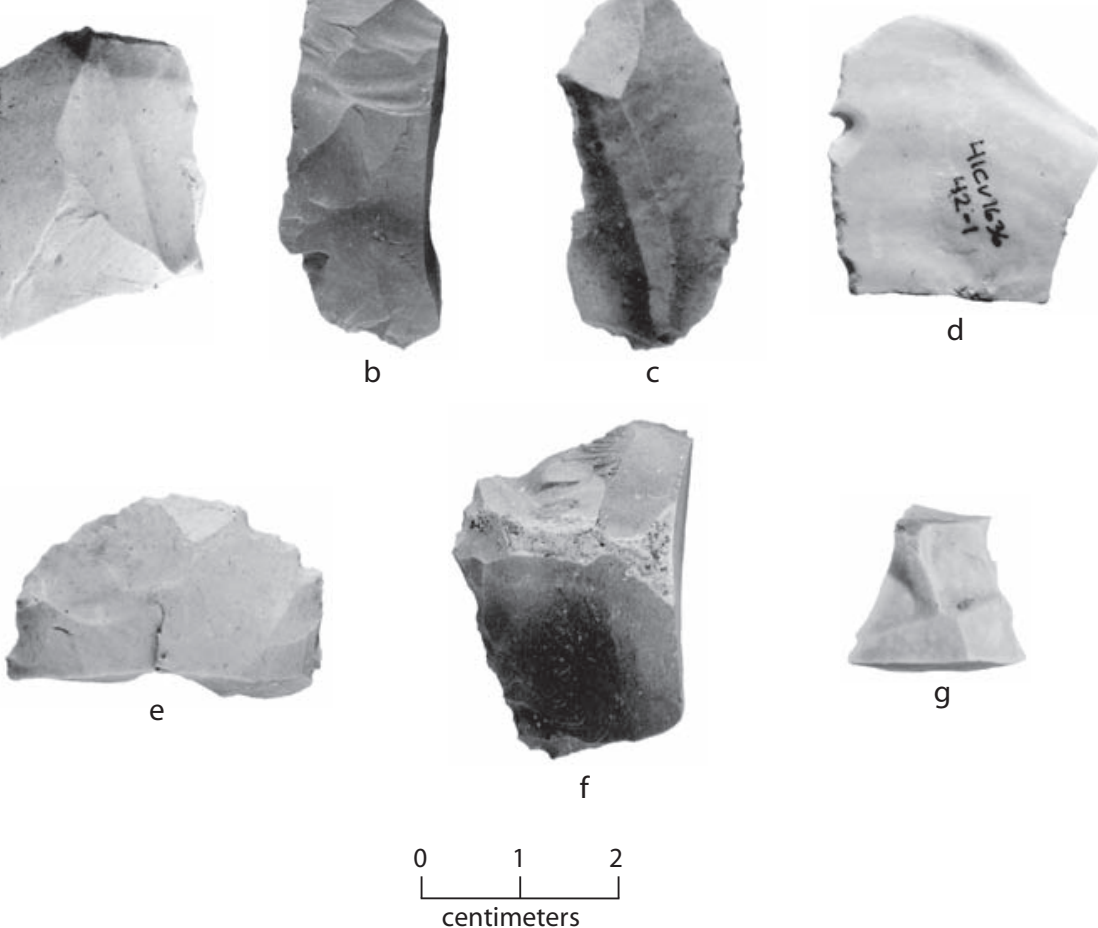

Figure 5.6. Utilized flakes and retouched tools. (a-d) utilized flakes; (e-g) retouched tool fragments. 
of white, fine-grained chert, has pronounced edge rounding and small $(<1 \mathrm{~mm})$ unifacial microscars with step terminations along one lateral edge remnant. The second specimen (Figure 5.6b) is a lateral flake fragment of mottled light gray and medium gray chert exhibiting primarily unifacial small microscars with feather and step terminations.

Material recovered from Test Unit 3 included four utilized flake tools, one each from Levels 6-9. Wear traces for each tool described below indicate that they were used in scraping materials of varying hardness. The specimen recovered from Level 6 (Figure 5.6c) was retrieved from a flotation sample taken from the west half of Feature 1 (99.64-99.55 m). This tool is a complete softhammer bifacial thinning flake having small unifacial microscars $(<1 \mathrm{~mm})$ with overlapping step and feather terminations, edge-rounding, and light polish present along one complete edge and the distal portion of the other edge.

The second example is from Level 7 between 99.54 and $99.44 \mathrm{~m}$ (60-70 $\mathrm{cm}$ below surface). It is a small, wedge-shaped flake segment retaining a portion of a lateral edge that has a concavity created by unifacial scars $(<1 \mathrm{~mm}$ in size) with feather terminations.

A distal flake fragment (Figure 5.6d) was recovered from Level 8 between 99.44 and $99.34 \mathrm{~m}$ (70-80 $\mathrm{cm}$ below surface). This particular tool has similar unifacial wear traces along one lateral edge. The chert is heavily patinated white in color and could not be assigned to a known chert type.

The final tool recovered from Level 9 between 99.34 and $99.24 \mathrm{~m} \mathrm{(80-90} \mathrm{cm} \mathrm{below}$ surface) is an angular fragment of grayish chert with chalcedony-like veined inclusions and a light white patina. Microscopic wear traces consist of unifacial scars $(<1 \mathrm{~mm})$ along one end with overlapping step and feather terminations and slight edge rounding.

Utilized flake tool wear characterized by small unifacial scars with step and feather terminations indicate use as scraping tools on a variety of materials. Before the debitage was analyzed, all debris was examined for edgemodified tools. It is interesting that only scraping is represented, suggesting that tool functions may have been limited to a few specific tasks, perhaps related to repair and maintenance of hunting equipment and other gear.

\section{Unifaces}

Retouched flakes were recovered from Test Unit 1 and Test Unit 3 in similar contexts as the utilized flakes discussed above. Three unifacially retouched flakes are from Test Unit 1, and one is from Test Unit 3.

Retouched implements from Test Unit 1 were recovered from Levels 8 and 10 . There are two from Level 8 between 99.42 and $99.32 \mathrm{~m}$ (70-80 cm below surface). One is a distal flake fragment (Figure 5.6e) that has been retouched along the distal edge, resembling the distal end of a small convex end scraper. The fracture surface of this fragment exhibits a negative bulb of percussion, which may indicate that the implement had been deliberately truncated, perhaps to create a new functional edge. Use wear on the edge consists of small microscars with step and feather terminations and light edge rounding. The second implement from this same context has similar use wear traces but is a small proximal flake fragment retouched along one edge. The chert material of both tools is heavily patinated. A third implement (Figure 5.6f) from Test Unit 1, Level 10, between 99.22 and $99.12 \mathrm{~m} \mathrm{(90-100} \mathrm{cm}$ below surface) is a flake fragment of medium to dark gray fine-grained chert with remnants of thin chalky cortex. Irregular retouch is present along one edge, and use wear consists of a mix of unifacial feather, step, and hinge-terminated microscars.

The single specimen (Figure 5.6g) from Test Unit 3 is a small edge fragment of a retouched flake that retains a portion of the modified edge. This tool was recovered from Level 9 between 99.24 and $99.34 \mathrm{~m}$ (80-90 $\mathrm{cm}$ below surface). Wear traces consist of continuous overlapping step-terminated microscars and moderate edge blunting but no polish. The chert material is fine-grained but patinated to almost a solid white color.

As with utilized flakes recovered at $41 C V 1636$, the small number of unifacially retouched flakes and fragments indicate that activities or tasks requiring the use of scraping implements were conducted. The importance of scraping tasks or tools at the site cannot be fully determined based on the limited data recovered. It may be significant that no edge-modified tools were identified that exhibited use wear traces attributable to cutting or other tasks. The preponderance of tools and tool fragments with scraping wear may coincide with the abundance 
of broken, abandoned, and worn-out projectile points. Along this line, tool kit maintenance and repair may have been major activities conducted in the tested portion of the site.

\section{Cores}

There were only three cores recovered from 41CV1636. These consist of two generalized percussion cores and a small tested streamworn cobble (Figure 5.7a-b). The scarcity of percussion cores in the lithic assemblage is also correlated to the low numbers of hardhammer percussion flakes represented among the unmodified debitage. The cores were not identified as any of the raw materials represented in the debitage. The tested cobble is comparable to chert type 1.

A tested cobble (Figure 5.7a) was recovered from Test Unit 1, Level 1, between 100.12 and $100.02 \mathrm{~m}$ (0-10 cm below surface). Raw material is a streamworn flat cobble of local medium gray chert with a yellow-brown to white streamworn chalky cortex, suggesting that it may not have been transported too far from its original bedrock source. Two percussion flakes were removed from one surface, and one flake was removed from the opposing surface. The cobble is $79.98 \mathrm{~mm}$ long, $63.59 \mathrm{~mm}$ wide, $31.07 \mathrm{~mm}$ thick, and weighs $146.5 \mathrm{~g}$.

Two general percussion cores were recovered from Test Unit 1, Level 8, between 99.42 and $99.32 \mathrm{~m}$ (70-80 $\mathrm{cm}$ below surface). Both are small multidirectional cores retaining patches of thin, chalky cortex, suggesting that they are from within the local drainage area of Cowhouse Creek and were not brought in from any extended distance. One core (Figure 5.7b) is heavily patinated entirely white and cannot be assigned to any of the known Fort Hood or Edwards Plateau chert types. This core also retains a remnant of a ventral surface and cortex striking platform, indicating that it was a larger percussion flake. Dimensions for this core are: length $51.35 \mathrm{~mm}$; width $44.08 \mathrm{~mm}$; thickness $20.45 \mathrm{~mm}$; weight $54.6 \mathrm{~g}$.

The second core excavated from the same context is a slightly translucent brown to yel-

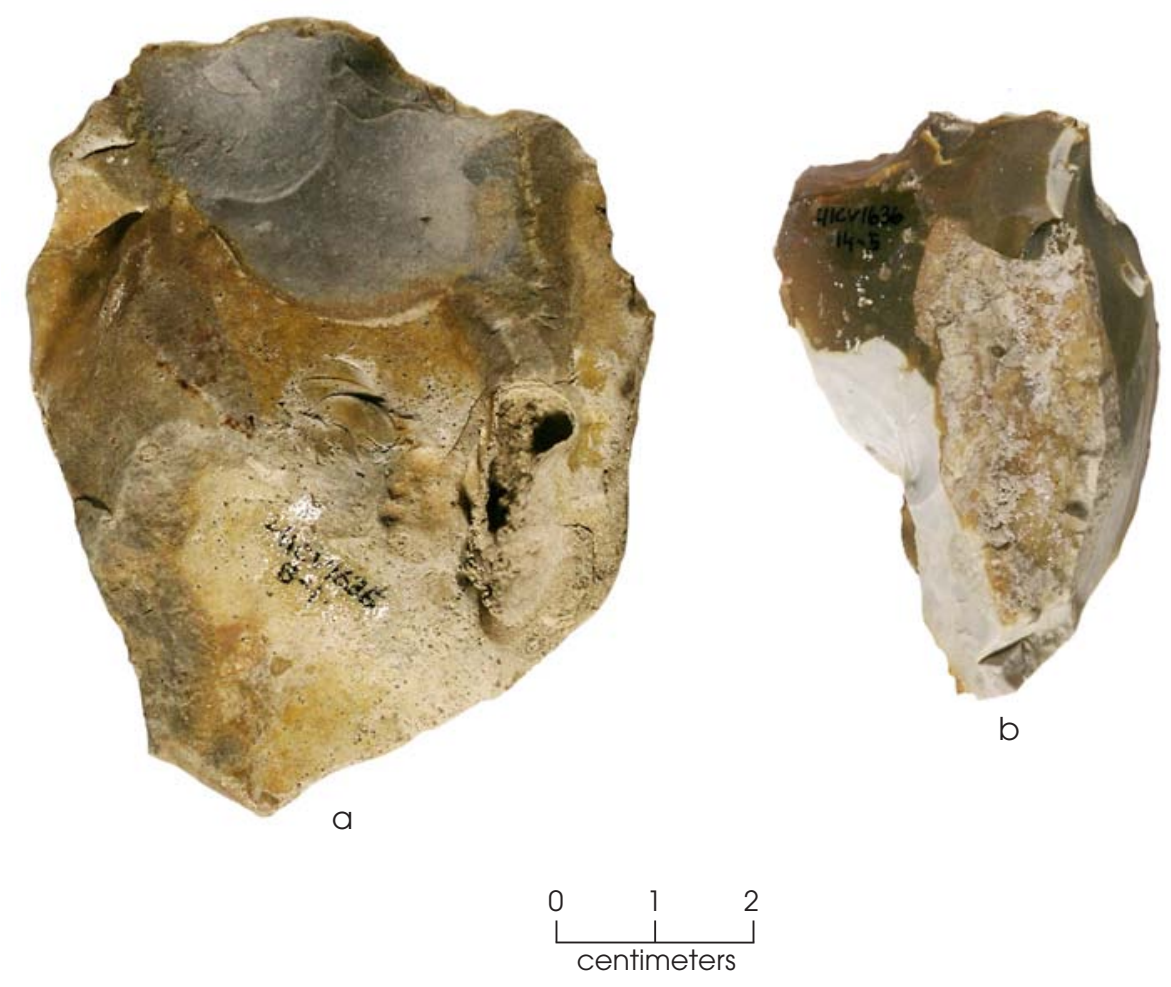

Figure 5.7. Cores. (a) tested cobble; (b) multidirectional core on a percussion flake. 
low-brown banded chert with patches of white patina. This core has cortex remnants on two surfaces, indicating that it was initially a small chert cobble, probably procured from the local gravel bedload of Cowhouse Creek. This core is $58.92 \mathrm{~mm}$ long; $33.02 \mathrm{~mm}$ wide; $23.19 \mathrm{~mm}$ thick; and weighs $47.0 \mathrm{~g}$.

\section{Refit Flakes}

During the excavation of Test Unit 1, two small flakes (Figure 5.8) of light gray, slightly patinated chert (probably chert type 1) were recovered from Level 12 between 99.02 and $98.92 \mathrm{~m}$ (110-120 cm below surface). There are no other indications of the presence of a core technique in the lithic assemblage. The small blade-like flake has no cortex and has a central ridge and two longitudinal flake scars. A single faceted striking platform with light dorsal edge grinding and a pronounced lip suggest that this flake was removed from a prepared platform by softhammer percussion. The corresponding flake that refits to the blade has a slightly crushed platform and a diffuse bulb of percussion. Given the absence of blade cores or other blade-related debitage, these refits were probably produced during biface manufacture. Dimensions of the blade-like flake are: length $27.31 \mathrm{~mm}$; width $8.72 \mathrm{~mm}$; thickness $2.38 \mathrm{~mm}$; weight $0.5 \mathrm{~g}$. Dimensions of the larger flake are: length $34.28 \mathrm{~mm}$; width $27.32 \mathrm{~mm}$; thickness $3.77 \mathrm{~mm}$; weight $2.6 \mathrm{~g}$.

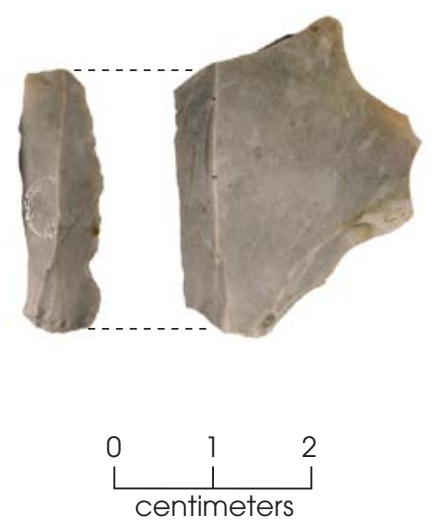

Figure 5.8. Refit small blade-like flake and larger flake.

\section{UNMODIFIED DEBITAGE}

Unmodified debitage represents 99 percent $(\mathrm{n}=2,544)$ of all recovered lithic artifacts, giving a ratio of flakes to tools/cores of $97: 1$. Test Units 1, 2, and 3 had the greatest abundance and density of unmodified debitage (96 percent of all debitage). Coupled with the presence of only two small cores and one tested cobble, this finding implies that tool repair or bifacial reduction were emphasized over production of flakes from generalized percussion cores. The highly fragmentary and resharpened character of recovered dart points also strongly suggests a lithic assemblage produced by an emphasis on tasks associated with tool maintenance and less emphasis on raw material procurement. The presence of a proximo-medial bifacial knife fragment and two distal fragments of Stage II bifaces also supports a lithic technology geared toward biface manufacture and bifacial tool maintenance. The discussion below begins with a brief description of identified raw materials and interpretations of the regional potential for lithic raw materials, followed by interpretations of debitage patterns.

\section{Raw Material Types}

A number of caveats should be mentioned regarding the identification of various chert types from sites along Cowhouse Creek beyond the range of known chert types on Fort Hood. Previous studies have reported that the identification of chert types from bedload gravels is particularly problematic given their resemblance to other chert types (Ellis et al. 1995:58; Boyd 1999:379). Ellis et al. (1995:58) indicate that darker gray hues of Cowhouse Dark Gray (Type 19) can be mistaken for examples of Owl Creek Black (Type 17), even though they are not geologically or geographically related. Smaller pieces of Cowhouse Mottled with Flecks (Type 22) can also be misidentified as fragments of Heiner Lake Tan (Type 6). In a series of blind chert type identification tests by several different analysts, the consensus regarding bedload cherts was that they are problematic and may not represent real chert types (Boyd 1999:379). A significant problem is that there are no criteria for describing the amount of variability within bedload cherts resulting from weathering or saturation while the nodule is part of the stream's clast material. 
A phenomenon observed on examples of Types $18-28$ is that there is a two-tone differentiation between a lighter outer zone and a darker inner zone of material. This study further concluded that Cowhouse Two Tone (Type 18), Cowhouse Dark Gray (Type 19), Cowhouse Mottled with Flecks (Type 22), and Cowhouse Banded and Mottled (Type 23) are not valid chert types and should be discarded from the Fort Hood chert type nomenclature.

During the debitage analysis, an effort was made to compare chert types from 41CV1636 to known chert types on Fort Hood (see Table 3.1). An abundance of small flake sizes and moderate to heavy patination on a majority of the sample defeated efforts to identify any Fort Hood chert types. Consequently, a generalized chert typology was developed. The chert types identified are broadly comparable in quality and appearance to the various Edwards Group formation cherts described and illustrated by Banks (1990:123-125).

Seven chert types were identified but could only be broadly compared to known Fort Hood chert types. These consist of three major types and five secondary types. Isolated examples of unique cherts were grouped within an indeterminate chert category.

Chert type 1 includes all flakes of a light to dark gray, with occasional to common small white flecks of coarser material. Scattered small bluish-white inclusions are present in some larger pieces. Munsell color variability for this category is light bluish-gray to bluishgray (Gley 2 7/5PB to Gley 2 5/10B). Patinated examples include lighter hues, and a few flakes were bluish black (Gley 2 2.5/FB). The raw material has apparent good to excellent conchoidal fracture and evidence of deliberate heat treatment was not observed. Burned examples did not exhibit signs of reddening but did show evidence of crazing, spalling, and potlid scars. The flecking observed as a characteristic of this material is also a common characteristic of several Fort Hood chert types. The closest comparable Fort Hood chert type to Chert Type 1 is East Range Flecked, which has a limited geographic occurrence near the northern end of Lake Belton. However, chert type 1 lacks the abundance of flecking observed in East Range Flecked.

Chert type 2 is comprised of medium to heavily patinated flakes of fine-grained opaque and translucent cherts. This group probably includes several area chert types. Color varies on heated examples to include subtle hues of pink, red, and occasionally pinkish-gray. White or off-white flecking was not present in this material. Conchoidal fracture varies from good to excellent, especially for more translucent examples. Mottling was common in many specimens.

Chert type 3 included pieces with white/offwhite coloring and slight banding. Munsell colors included Gley 1 8/N and 10YR 5/8. Conchoidal fracture was excellent, and the material was moderately patinated. Heat treatment was not observed. This was the only banded chert observed in the unmodified debitage from 41CV1636.

Chert type 4 may represent less patinated or unpatinated specimens of chert type 2 described above, with translucent to opaque examples common. Varying hues of 10YR and 5YR are common. Chert types 2 and 4 are considered to represent undifferentiated cherts of the Edwards Group. Conchoidal fracture was good to excellent, and some specimens appear to have been heat treated.

Chert type 5 consists of a fine-grained opaque chert with a chalky off-white to grayish cortex. Color varies from a very pale brown (10YR $8 / 2$ ) to yellow (10YR 7/4), and heated examples exhibit varying shades or light to medium red or orange brown hues of color. Lightly heated flakes are slightly pink. Conchoidal fracture is good to excellent. Some mottling of colors is observed, with inclusions of more translucent brown material in some larger flakes. No flecking is present.

Chert type 6 is a translucent to cloudy white fine-grained material with reddish staining and light patination. The translucency and reddish to reddish orange staining are very similar to that described for Seven Mile Novaculite. Although represented by only two pieces of unmodified debitage, this material is a possibility. Seven Mile Novaculite occurs as a source material to the southwest of Copperas Cove, Texas.

Chert type 7 represents single flakes of chert types that could not be placed within one of the above larger groupings. Little can be said regarding reduction or manufacture techniques associated with these materials. Color is variable.

There appears to be little room for direct comparison between chert types from 41CV1636 and those known to occur along Cowhouse Creek 
as it flows through Fort Hood. Reasons would include differences in local geology and stream bedload characteristics. Prehistoric raw material selection choices based on locally available chert types also contributed to the raw material differences between those types from 41CV1636 and Fort Hood.

\section{Raw Material Catchment}

Within a $20-\mathrm{km}$ radius of $41 \mathrm{CV} 1636$ on Cowhouse Creek, several drainages and divides provide potential sources of lithic material (Figure 5.9). From southwest to northeast, these include portions of the Lampasas River/Bennett Creek confluence, House Creek to its confluence with Cowhouse Creek, Cowhouse Creek, Plum Creek and its confluence with the Leon River, and a stretch of the Leon River from just east of Hamilton to Gatesville. There are three potential zones of procurement for raw material: the stream gravels and Holocene and Quaternary gravels and terraces, bedrock exposures along the streams at the valley walls, and any available exposures along the upland divides. Along Cowhouse Creek, upstream and downstream from 41CV1636, there are 13 mapped Quaternary terrace deposits. Three larger remnants of Quaternary terraces are mapped along portions of the Leon River within $20 \mathrm{~km}$ of the site.

Stream valley walls are primarily eroded into the Lower Cretaceous Glen Rose Formation, and the upland divides are predominantly the Walnut Formation. Neither of these formations are particularly abundant with chert, and in fact may be considered chert free. Edwards limestone exposures occur to the west and southwest of $41 \mathrm{CV} 1636$ between 10 and $20 \mathrm{~km}$. Edwards limestone comprises portions of the upland divide between the Lampasas River and Cowhouse Creek. Duck Creek limestone and Kiamichi Clay outcrop $20 \mathrm{~km}$ northeast of the site, east of the Leon River, but they are also poor in cherts.

The best sources of bedrock raw material are to the south and west of 41CV1636. To the north and east of the site, potential raw material sources consist of stream gravels and Quaternary terrace remnants along the Leon River. A thin zone of Edwards Formation rocks east of the Leon River and another area southeast at the edge of the $20-\mathrm{km}$ catchment could also have been a source of suitable bedrock chert. Certainly to the north and east, suitable sources of raw material become more scarce until one enters the Bosque and Brazos River drainages near Waco with abundant Quaternary terrace deposits and remnant Quaternary High Gravels. These drainages also are potential sources of more Edwards Formation bedrock cherts. The channel of Cowhouse Creek itself would have been a suitable chert procurement source, farther to the southeast as it flows into the Fort Hood area. Here the creek flows through an area that has potentially more sources of bedrock chert to be contributed to the creek bedload. In the vicinity of 41CV1636, Cowhouse Creek was a poor source of suitable cherts for manufacturing flaked stone tools, particularly bifacial knives and projectile points. The scarcity of cortex, specifically streamworn and abraded types, in the lithic assemblage indicates that procurement from any adjacent gravel lithic sources was very limited. Low cortex numbers, limited evidence of percussion core flaking, and an absence of bifaces in early stages of manufacture suggest that raw material procurement activities may have been of minimal importance as a task at 41CV1636. Considering the scarcity of suitable material in the immediate vicinity (between 5 and $10 \mathrm{~km}$ of 41CV1636), the site may be viewed as in a transition zone between raw material source areas to the northeast, southwest, and southeast.

\section{Unmodified Debitage Patterns}

Characteristic of most sites in central Texas, the most abundant artifact category recovered from 41CV1636 was unmodified lithic debitage. Analysis of unmodified debitage focused on identification of raw materials, size grading, and determination of flake types present within the assemblage. Flake aggregate analysis or size grading shifts the focus of analysis from individual flakes to flake assemblages. This approach is ideally suited to assemblages with large numbers of flakes and/or assemblages dominated by small sizes of unmodified debris not suitable for detailed and time-consuming attribute analyses. One assumption made in this study is that specific flake types can be identified that are indicative of distinct flaking techniques.

Although it is acknowledged that similar flake types can be produced by a variety of techniques, it was decided that the debitage 


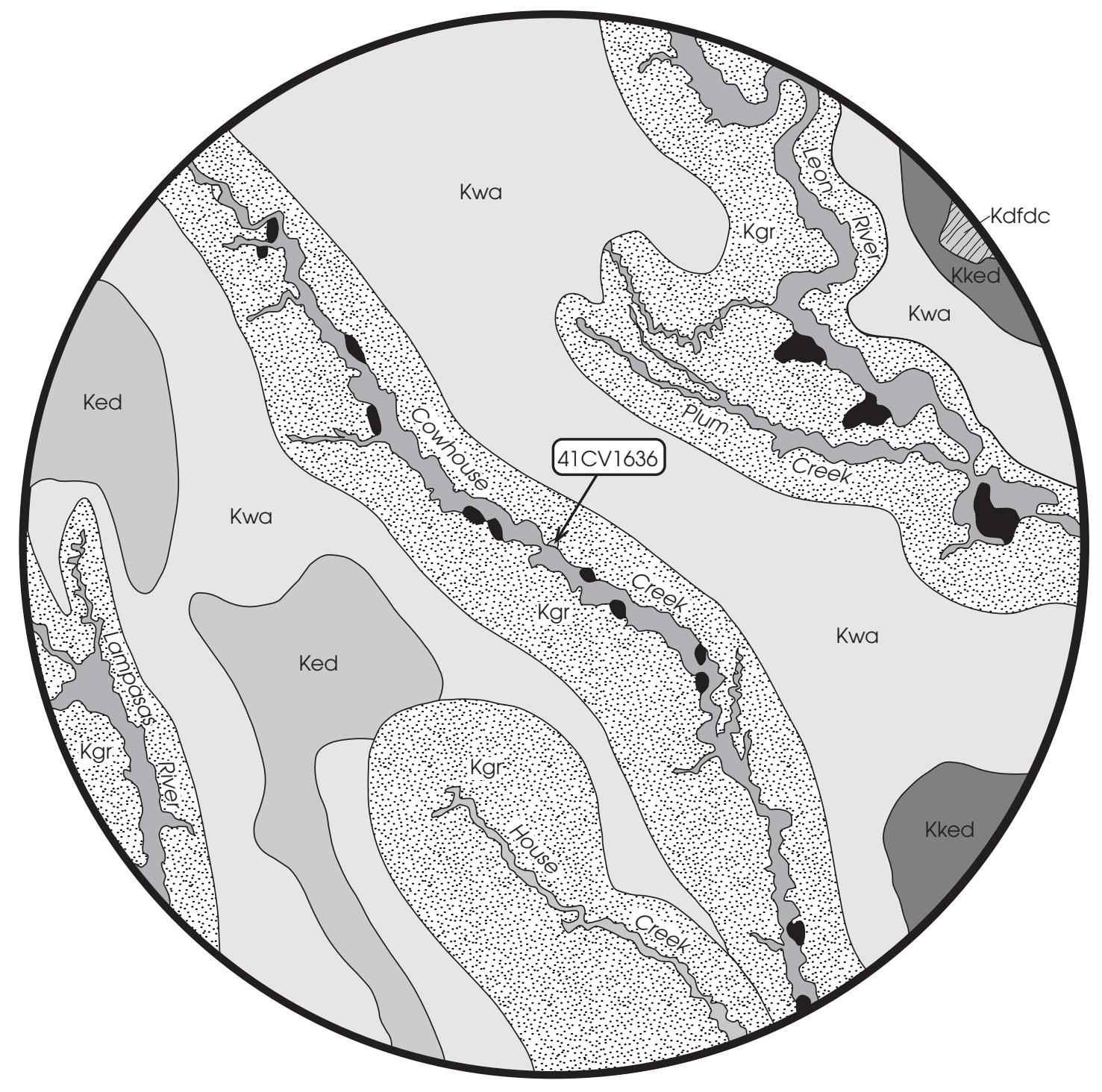

$L E G E N D$

- Quaternary Terrace

Ked Edwards Limestone

Kked Kiamichi Clay \& Edwards Limestone

Kwa Walnut Formation

Kgr: Glen Rose Formation

Kdifd Denton Clay

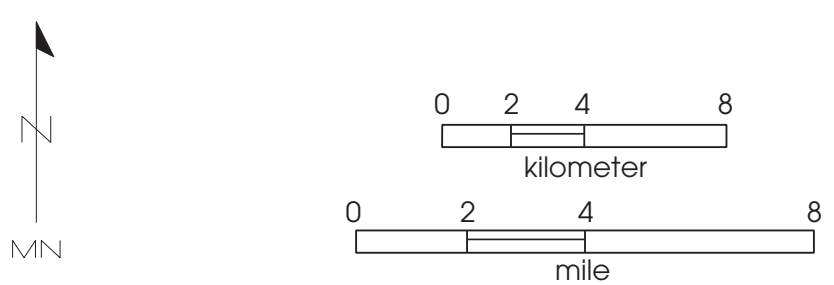

$P A I / 06 / B W$

Figure 5.9. The $20-\mathrm{km}$ radius around $41 \mathrm{CV} 1636$ shows potential sources of lithic raw material. 
from 41CV1636 was amenable to identification of specific flake types. Flake type categories were defined on the basis of previous experience in lithic analysis, a clear perception of fracture mechanics, and understanding in lithic technological studies of what attributes typically are "understood" to define particular flake types. Flake types selected for this analysis are described earlier in this report. Much like the identification of specific projectile point styles, flake types are identified based on assessments of multiple lines of morphological, technological, size grade data and qualitative interpretations of combinations of these lines of inquiry. It is acknowledged that there is undoubtedly some technological overlap between some flake categories identified in this study (for instance between notching flakes and punch flakes) but that technological characteristics between flake types are sufficiently distinct to allow their identification in the archeological assemblage. During the initial sorts of unmodified debitage from 41CV1636, observations were made that deemed the above analytical approach as appropriate. First was the virtual absence of debris that is technologically comparable to generalized percussion core or hardhammer flake production. Second, a high proportion of broken debris and a preponderance of flakes comparable to biface thinning suggested a debitage assemblage representing a restricted technological origin having little mixing of different reduction techniques. Third, the unmodified debitage was overwhelmingly represented by small and very small flake sizes characteristic of late-stage reduction and/or small tool manufacture. The predominance of projectile points and biface fragments over utilized flakes and unifaces also suggested a lithic assemblage produced by a narrow range of flaking techniques. Certainly, flaked tool manufacture and general percussion core reduction were not being conducted in any great abundance within the tested portion of the site. It is argued that the character of the unmodified debitage from 41CV1636 is suitable for the identification of particular types of flakes because those types of knapping techniques were applied in sufficient abundance that they can be recognized in the archeological record. This is a direct argument for the existence of stages in lithic manufacture (Bradbury and Carr 1999:106).
To further interpret the unmodified debitage assemblage from 41CV1636, the assemblage is briefly compared to other size-graded experimental debitage data sets. The experimental sets all have a significant biface component for comparison and are briefly discussed below.

The first comparative debitage sample was produced as part of a replication experiment to produce a Clovis point and to quantify differences between manufacture stages (Henry et al. 1976). The experiment produced 1,202 flakes. The experiments were conducted by Bruce Bradley.

The second comparative sample of flake debris was produced by J. B. Sollberger as part of a demonstration for members of the South Texas Archaeological Association (Gunn and Mahula 1977; Gunn et al. 1976). Sollberger's demonstration was geared to show three basic stages in the biface reduction process: cortex removal and preforming, shaping and thinning, and sharpening. The manufacture process resulted in the completion of a large, corner-notched dart point similar in shape and size to the Marcos and Marshall types. This experiment in biface reduction toward dart point manufacture produced an assemblage of 522 flakes.

The third experimental flake assemblage was produced by Glenn Goode as part of the interpretive analysis for material excavated from the Bull Pen site (41BP280) in Bastrop County (Ensor et al. 1988). Goode's replications were devoted to manufacture of 10 Pedernales points utilizing chert cobbles from the Willis and Uvalde gravels and material from Colorado River terraces (Goode 1988). He perceived three manufacturing stages: initial, intermediate, and final. The experiments produced a total of 2,900 flakes.

The fourth comparative assemblage was produced by Patterson and Sollberger (1978) as part of a series of biface manufacture experiments designed to quantify differences between small debitage produced by different flaking techniques: pressure flaking, hard hammerstone, soft billet, soft hammerstone, and indirect percussion. The importance of this sample for comparative purposes is significant given the inclusion of indirect percussion as part of the experimental structure. This experimental set is also important because the sample was segregated into known flake types, and direct comparisons of size distributions can be made with archeological material from 41CV1636. 
One important aspect of each of these experimental data sets (Table 5.6) is that flakes were segregated by flake type based on the type of percussor used during the flintknapping process. This allows one to segregate size-graded debris during analysis by flake production techniques. Closer comparisons can be made between the experimental assemblages and material recovered from 41CV1636. The size of experimental data sets is not considered to be a significant limiting factor because each segment represents a discrete and controlled behavior or set of behaviors associated with different aspects of biface and dart point manufacture.

The unmodified debitage sample included all flakes from Test Units 1, 2 and 3 (excluding material from flotation samples) and totals 2,208 pieces. Material from Test Unit 4 was omitted due to small sample size. However, the raw material colors observed in the sample recovered from Test Unit 4 are comparable to those obtained from Test Units 1, 2, and 3.

Proportions of different raw materials between test units are comparable for the most abundant chert types (Table 5.7). An examination of chert types by size grade shows the predominance of debris within small size classes (Table 5.8; Figure 5.10). The sample is made up of identifiable flakes and fragments (37 percent), indeterminate flake fragments (missing striking platforms) (58 percent), and burned and unburned shatter (5 percent). Just over 90 percent of the debitage was confined to size classes 1 and 2 (92 percent, $\mathrm{n}=2,024$ ), indicating that a large proportion of the assemblage was less than $10 \mathrm{~mm}$ in maximum dimension. Brief comparison with the experimental data sets demonstrates that an abundance of flakes within small size grades (typically less than 10-15 mm in maximum dimension) characterize debris assemblages created during dart point manufacture and late-stage biface finishing activities. Proportions of similar size grade data from these experiments was 40 percent (Gunn et al. 1976), 79 percent (Goode 1988), and 89 percent (Henry et al. 1976).

Evidence of cortex, deliberate heat treatment and burning provides information on the character of raw material in the assemblage. Cortex abundance for recovered material corresponds to the abundance of small flake sizes, with 96 percent $(n=2,117)$ of all analyzed unmodified debitage having no cortex. Cortex of varying amounts was present on only 4 percent ( $\mathrm{n}=91$ pieces $)$. Pieces with complete dorsal cortex represent only 1 percent $(n=21)$ of the sample, while other pieces with partial cortex represent a combined total of only 3 percent $(\mathrm{n}=70)$. Cortex could be divided into several categories: abraded/weathered chalky white $(\mathrm{n}=4)$, chalky white streamworn $(\mathrm{n}=7)$, chalky white unweathered $(n=15)$, chalky stained unweathered $(\mathrm{n}=8)$, thin streamworn $(\mathrm{n}=14)$, and patinated cortex $(\mathrm{n}=1)$. Evidence of deliberate heat treating was only visible on 8 specimens, indicating that preforms or other tool blanks brought to the site were not deliberately altered. Despite the fact that there were two burned rock features at the site, the abundance of burned flakes and burned shatter was low. The total number of burned flakes is 14 , and the total number of burned shatter pieces is 48 . In total, heat treated and burned pieces represent only 3 percent of all unmodified debitage.

Chert types 1, 2, and 4 were the most abundant materials at 41CV1636. Chert types 1 and 2 represent a combined total of 92 percent of the unmodified debitage. Type $1(\mathrm{n}=907)$ is 41 percent, and type $2(n=1,117)$ is 51 percent of all debitage. Proportions of different chert types are comparable between Test Units 1, 2, and 3 . There does not appear to have been any concentrated reduction of material in any of the test units analyzed. These chert types provide the best glimpse of lithic-related activities that probably occurred at 41CV1636. Acknowledging difference in sample size and the general problems of flake type identification, the proportions of different flake types between these three materials are striking in their concordance (Table 5.9). Although we cannot address the number of occupations or whether the site represents a single occupation, the uniformity in debitage patterns argues for rather uniform activities conducted over a rather short span of occupation(s).

Distribution of different flake types by size class (Table 5.10; Figure 5.11) for unmodified debitage at 41CV1636 reveals distinct patterns comparable to those of similar debris categories produced experimentally. Hardhammer and biface thinning flakes are associated with larger size classes. This trend is also observed in the experimental datasets. The upper size limits of these flake types correspond closely to the 
Table 5.6. Experimental debitage data sets for comparison with 41CV1636

\begin{tabular}{|c|c|c|c|c|c|c|c|c|c|}
\hline Size Grade & $\begin{array}{c}\text { Hard- } \\
\text { hammer }\end{array}$ & $\begin{array}{c}\text { Cum. } \\
\text { Totals }\end{array}$ & $\begin{array}{c}\text { Cum. } \\
\%\end{array}$ & $\begin{array}{c}\text { Soft- } \\
\text { hammer }\end{array}$ & $\begin{array}{l}\text { Cum. } \\
\text { Totals }\end{array}$ & $\begin{array}{c}\text { Cum. } \\
\%\end{array}$ & Pressure & $\begin{array}{l}\text { Cum. } \\
\text { Totals }\end{array}$ & $\underset{\%}{\mathrm{Cum}}$ \\
\hline $25 \mathrm{~mm}$ & 17 & 17 & 2.37 & 29 & 29 & 3.45 & - & - & - \\
\hline $19 \mathrm{~mm}$ & 34 & 51 & 7.12 & 34 & 63 & 7.49 & - & - & - \\
\hline $16 \mathrm{~mm}$ & 30 & 81 & 11.31 & 44 & 107 & 12.72 & - & - & - \\
\hline $13 \mathrm{~mm}$ & 48 & 129 & 18.01 & 74 & 181 & 21.52 & - & - & - \\
\hline $10 \mathrm{~mm}$ & 105 & 234 & 32.67 & 123 & 304 & 36.15 & - & - & - \\
\hline $4 \mathrm{~mm}$ & 482 & 716 & 100.00 & 537 & 841 & 100.00 & 183 & 183 & \\
\hline Total & 716 & & & 841 & & & 183 & & \\
\hline
\end{tabular}

Gunn et al. 1976 experimental projectile point manufacture data

\begin{tabular}{lccccccccc}
\hline Size Grade & Phase I & $\begin{array}{c}\text { Cum. } \\
\text { Totals }\end{array}$ & $\begin{array}{c}\text { Cum. } \\
\%\end{array}$ & Phase II & $\begin{array}{c}\text { Cum. } \\
\text { Totals }\end{array}$ & $\begin{array}{c}\text { Cum. } \\
\%\end{array}$ & $\begin{array}{c}\text { Cum. } \\
\text { Phase III }\end{array}$ & $\begin{array}{c}\text { Cum. } \\
\text { Totals }\end{array}$ & $\begin{array}{c}\text { \% } \\
\text { Po }\end{array}$ \\
\hline $80 \mathrm{~mm}$ & 3 & 3 & 1.52 & - & - & - & - & - & - \\
$40-80 \mathrm{~mm}$ & 23 & 26 & 13.20 & - & - & - & - & - & - \\
$20-40 \mathrm{~mm}$ & 30 & 56 & 28.43 & 16 & 16 & 6.72 & - & - & - \\
$10-20 \mathrm{~mm}$ & 48 & 104 & 52.80 & 38 & 54 & 19.10 & 15 & 15 & 14.71 \\
$4.49-10 \mathrm{~mm}$ & 93 & 197 & 100.00 & 184 & 238 & 100.00 & 72 & 87 & 100.00 \\
$<4.49 \mathrm{~mm}^{*}$ & 351 & & & & & & & & \\
\hline
\end{tabular}

* Material in this size range was not included in analysis by Gunn etl al. 1976.

Goode 1988 experimental Pedernales point manufacture data

\begin{tabular}{lccccccr}
\hline Size Grade & $\begin{array}{c}\text { Total } \\
\text { Counts }\end{array}$ & $\begin{array}{c}\text { Cum. } \\
\text { Totals }\end{array}$ & $\begin{array}{c}\text { Cum. } \\
\%\end{array}$ & Hardhammer $\%$ & $\begin{array}{c}\text { Cum. } \\
\%\end{array}$ & Softhammer \% & $\begin{array}{c}\text { Cum. } \\
\%\end{array}$ \\
\hline $1(\geq 36 \mathrm{~mm})$ & 40 & 40 & 1.38 & 2.87 & 2.87 & 5.35 & 5.35 \\
$2(36-25 \mathrm{~mm})$ & 174 & 214 & 7.38 & 12.03 & 14.90 & 21.63 & 26.98 \\
$3(25-17 \mathrm{~mm})$ & 401 & 615 & 21.21 & 35.24 & 50.14 & 34.88 & 61.86 \\
$4(17-12 \mathrm{~mm})$ & 603 & 1218 & 42.00 & 49.86 & 100.00 & 38.14 & 100.00 \\
$5(<12 \mathrm{~mm})$ & 1,682 & 2,00 & 100.00 & (not included) & & (not included) \\
\hline
\end{tabular}

Patterson and Sollberger 1978 experiments in small debitage*

\begin{tabular}{|c|c|c|c|c|c|c|c|c|c|c|}
\hline Size Grade & Pressure & Cum. & $\begin{array}{c}\text { Hard } \\
\text { hammer- } \\
\text { stone }\end{array}$ & Cum. & $\begin{array}{c}\text { Soft } \\
\text { billet }\end{array}$ & Cum. & $\begin{array}{c}\text { Soft } \\
\text { hammer- } \\
\text { stone }\end{array}$ & $\underset{\%}{\text { Cum. }}$ & Indirect & $\begin{array}{c}\text { Cum. } \\
\%\end{array}$ \\
\hline $16-18 \mathrm{~mm}$ & 2 & 1.80 & 5 & 3.40 & 7 & 4.68 & 2 & 6.67 & 5 & 10.43 \\
\hline $14-16 \mathrm{~mm}$ & 2 & 3.60 & 7 & 8.16 & 8 & 10.01 & 2 & 13.34 & 7 & 25.01 \\
\hline $12-14 \mathrm{~mm}$ & 4 & 7.20 & 13 & 17.00 & 8 & 15.34 & 2 & 20.01 & 4 & 33.34 \\
\hline $10-12 \mathrm{~mm}$ & 11 & 17.11 & 20 & 30.61 & 15 & 25.34 & 4 & 33.34 & 7 & 47.92 \\
\hline $8-10 \mathrm{~mm}$ & 23 & 37.83 & 29 & 50.34 & 44 & 54.67 & 7 & 56.67 & 4 & 56.25 \\
\hline $6-8 \mathrm{~mm}$ & 69 & 100.00 & 73 & 100.00 & 68 & 100.00 & 13 & 100.00 & 21 & 100.00 \\
\hline
\end{tabular}

* Cumulative totals are omitted because the sample represents only a portion of a complete biface reduction sequence. 
Table 5.7. Proportion of different chert types at 41CV1636

\begin{tabular}{ccccccccc}
\hline $\begin{array}{c}\text { Chert } \\
\text { Type }\end{array}$ & \multicolumn{2}{c}{ TU 1 } & \multicolumn{2}{c}{ TU 2 } & \multicolumn{2}{c}{ TU 3 } & \multicolumn{2}{c}{ Site Total } \\
\hline & Total & $\%$ & Total & $\%$ & Total & $\%$ & Total & $\%$ \\
\cline { 2 - 9 } 1 & 292 & 35.35 & 326 & 46.91 & 289 & 42.07 & 907 & 41.08 \\
2 & 463 & 56.05 & 325 & 46.76 & 329 & 47.89 & 1,117 & 50.59 \\
3 & - & - & 2 & 0.29 & 3 & 0.44 & 5 & 0.23 \\
4 & 65 & 7.87 & 22 & 3.17 & 44 & 6.40 & 131 & 5.93 \\
5 & 5 & 0.60 & 17 & 2.45 & 14 & 2.04 & 36 & 1.63 \\
6 & - & - & - & - & 2 & 0.29 & 2 & 0.09 \\
7 & 1 & 0.12 & 3 & 0.43 & 6 & 0.87 & 10 & 0.45 \\
\hline & 826 & 100.00 & 695 & 100.00 & 687 & 100.00 & 2,208 & 100.00 \\
\hline
\end{tabular}

Table 5.8. Size grade by chert type

\begin{tabular}{lcccccccccc}
\hline Size Grade-in. $(\mathrm{mm})$ & 1 & 2 & 3 & 4 & 5 & 6 & 7 & Total & $\%$ & Cum. \% \\
\hline$<0.25(<6.3)$ & 274 & 277 & 2 & 33 & 8 & 1 & 1 & 596 & 27.00 & 27.00 \\
$0.25-0.38(6.3-9.5)$ & 392 & 517 & 1 & 46 & 17 & 1 & 5 & 979 & 44.34 & 71.34 \\
$0.38-0.50(9.5-12.5)$ & 143 & 185 & 1 & 32 & 6 & - & 3 & 370 & 16.76 & 88.10 \\
$0.50-0.75(12.5-19.0)$ & 88 & 118 & 1 & 12 & 3 & - & 1 & 223 & 10.09 & 98.19 \\
$0.75-1.00(19.0-25.0)$ & 5 & 18 & - & 6 & 1 & - & - & 30 & 1.35 & 99.54 \\
$1.00-1.50(25.0-37.5)$ & 5 & 1 & - & 2 & 1 & - & - & 9 & 0.41 & 99.95 \\
$1.50-2.00(37.5-50.0)$ & - & 1 & - & - & - & - & - & 1 & 0.05 & 100.00 \\
\hline Total & 907 & 1,117 & 5 & 131 & 36 & 2 & 10 & 2,208 & - & - \\
\hline$\%$ Raw Materials & 41.08 & 50.59 & 0.23 & 5.93 & 1.63 & 0.09 & 0.45 & 100.00 & 100.00 & - \\
\hline
\end{tabular}

maximum widths of Stage II biface fragments recovered from the site, suggesting that biface finishing and/or dart point manufacture began with bifacial preforms of $\pm 50 \mathrm{~mm}$ maximum width, possibly slightly larger since maximum flake size cannot exceed the width of the flaked piece. Flake type size distributions further indicate that both hardhammer and softhammer percussion were applied throughout the manufacture sequence.

The size distribution of punch flakes follows closely those of hardhammer and biface thinning flakes, indicating that the punch technique was applied sporadically during manufacture. The abundance of punch flakes demonstrates that it was not the primary flaking technique for making bifaces, but appears to have been used periodically to solve specific knapping problems or may have been associated with platform or surface preparation. Of the sample of 108 identified punch flakes, six appear to have been removed as efforts to correct specific knapping problems common in biface manufacture: remove concentrations of hinge terminations along a biface edge $(n=3)$, removal of thick areas $(n=2)$, and removal of a collapsed platform area $(n=1)$. In general, punch flakes appear to have been produced during thinning phases of biface shaping, with the technique being applied in concert with the use of a softhammer to thin bifaces. Additional indications of biface manufacture can be found in the presence of biface edge collapse flakes associated with chert types $1(n=5), 2(n=9)$, and $4(\mathrm{n}=2)$. It is possible that some of the biface edge collapse flakes represent knapping errors produced by indirect percussion as well. That indirect percussion would not have been an efficient method of completely flaking bifaces is supported by experimental observations of Sollberger: general awkwardness of holding the preform, extended time for manufacture as compared to direct percussion, and requirement of more extensive platform preparation (Patter- 


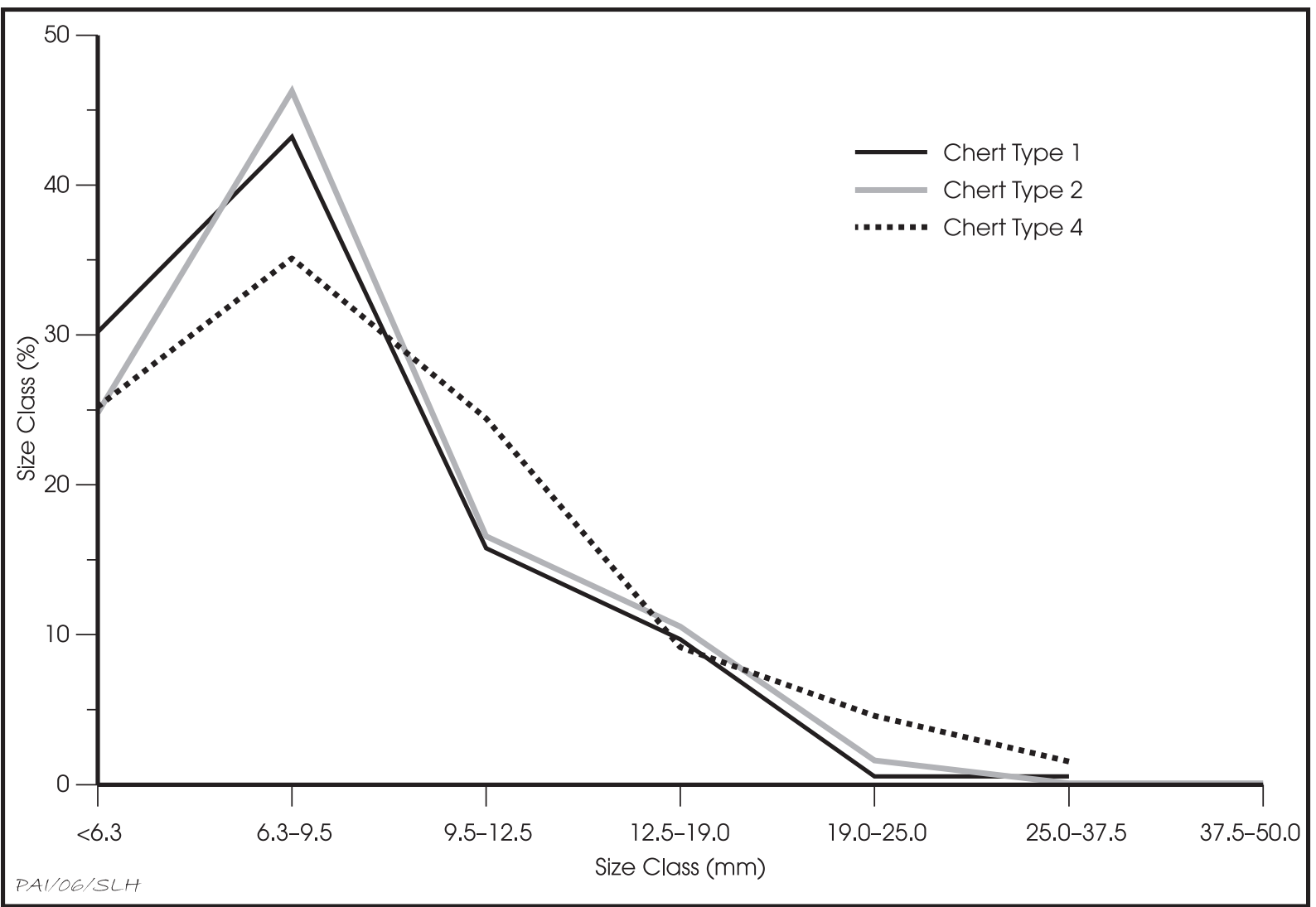

Figure 5.10. Distribution curves for chert types and size grade.

Table 5.9. Flake type by chert type

\begin{tabular}{lccccccccc}
\hline Flake Type & 1 & 2 & 3 & 4 & 5 & 6 & 7 & Total & $\%$ \\
\hline Bifacial Thinning & 189 & 208 & - & 19 & 11 & - & 3 & 430 & 19.47 \\
Biface Edge Collapse & 5 & 9 & - & 2 & - & - & - & 16 & 0.72 \\
Notching & 5 & 16 & - & 1 & - & - & 1 & 23 & 1.04 \\
Pressure & 60 & 83 & - & 5 & 4 & - & - & 152 & 6.88 \\
Punch & 33 & 59 & - & 13 & 3 & - & - & 108 & 4.89 \\
Bipolar & 3 & - & - & - & - & - & - & 3 & 0.14 \\
Core Platform Rejuvenation & - & 1 & - & - & - & - & - & 1 & 0.05 \\
Hard Hammer & 25 & 40 & - & 9 & 1 & - & - & 75 & 3.40 \\
Uniface Resharpening & - & 1 & - & - & - & - & - & 1 & 0.05 \\
Unburned Shatter & 18 & 22 & - & 6 & 3 & 1 & 1 & 51 & 2.31 \\
Burned Shatter & 15 & 18 & 2 & 10 & - & - & 3 & 48 & 2.17 \\
Hammerstone Spall & 1 & - & - & - & - & - & - & 1 & 0.05 \\
Indeterminate & 553 & 660 & 3 & 66 & 14 & 1 & 2 & 1,299 & 58.83 \\
\hline Flake Total & 907 & 1,117 & 5 & 131 & 36 & 2 & 10 & 2,208 & - \\
\hline \% Raw Materials & 41.08 & 50.59 & 0.23 & 5.93 & 1.63 & 0.09 & 0.45 & 100.00 & 100.00 \\
\hline
\end{tabular}


Table 5.10. Flake type by size grade

Size Grade-in. (mm)

\begin{tabular}{|c|c|c|c|c|c|c|c|c|c|}
\hline Flake Type & 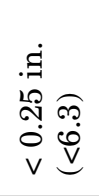 & 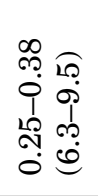 & 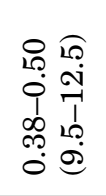 & $\begin{array}{ll}20 & 0 \\
5 & 0 \\
0 & 0 \\
1 & 1 \\
0 & 0 \\
0 & 0 \\
0 & 0 \\
0 & 0\end{array}$ & 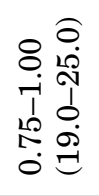 & 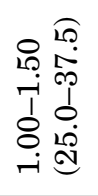 & 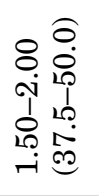 & Total & $\%$ \\
\hline Bifacial Thinning & 45 & 214 & 95 & 64 & 11 & 1 & - & 430 & 19.47 \\
\hline Biface Edge Collapse & 3 & 8 & 5 & - & - & - & - & 16 & 0.72 \\
\hline Notching & 10 & 13 & - & - & - & - & - & 23 & 1.04 \\
\hline Pressure & 104 & 47 & 1 & - & - & - & - & 152 & 6.88 \\
\hline Punch & 8 & 57 & 22 & 21 & - & - & - & 108 & 4.89 \\
\hline Bipolar & 1 & 2 & - & - & - & - & - & 3 & 0.14 \\
\hline Core Platform Rejuvenation & - & - & - & 1 & - & - & - & 1 & 0.05 \\
\hline Hard Hammer & - & 10 & 29 & 23 & 8 & 4 & 1 & 75 & 3.40 \\
\hline Uniface Resharpening & - & - & - & 1 & - & - & - & 1 & 0.05 \\
\hline Unburned Shatter & 14 & 26 & 4 & 5 & 1 & 1 & - & 51 & 2.31 \\
\hline Burned Shatter & 12 & 27 & 4 & 3 & 2 & - & - & 48 & 2.17 \\
\hline Hammerstone Spall & - & - & - & - & 1 & - & - & 1 & 0.05 \\
\hline Indeterminate & 399 & 575 & 210 & 105 & 7 & 3 & - & 1,299 & 58.83 \\
\hline Flake Total & 596 & 979 & 370 & 223 & 30 & 9 & 1 & 2,208 & - \\
\hline \% Size Grade & 27.00 & 44.34 & 16.76 & 10.09 & 1.35 & 0.41 & 0.05 & - & 100.00 \\
\hline
\end{tabular}

son and Sollberger 1978:108). However, there is little published data available on the use of this technique to augment the manufacture process or on its use as an aid to resolving knapping errors, for which its use at 41CV1636 is inferred. Further experimentation on the applications of indirect percussion as one of several flaking techniques in Archaic period lithic technology should be conducted.

Flake types such as pressure and notching are primarily restricted to the smaller size classes 1 through $3(6.3-12.5 \mathrm{~mm})$ and are presumed to be most often related to very late or final efforts of formal biface and projectile point manufacture. Punch flakes from $41 \mathrm{CV} 1636$ were most abundant in size class $2(6.3-9.5 \mathrm{~mm})$ but were also common in size classes 3 and 4 (9.5-19.0 mm). Pressure, notching, and punch flakes represent a combined total of 13 percent of all unmodified debitage and 31 percent of all identifiable flakes and proximal flake fragments. In comparison, hardhammer flakes represent only 3 percent of all unmodified debitage and 8 percent of all identified flakes and fragments. Patterson and
Sollberger (1978:110) produced similar flakes in nearly identical size ranges while manufacturing a series of five experimental bifaces between ca. 70 and $110 \mathrm{~mm}$ maximum length and ca. 30 $55 \mathrm{~mm}$ maximum width. Size distributions for experimental pressure flakes ranged between 6 and $12 \mathrm{~mm}$, and indirect percussion (punch) flakes were concentrated between 6 and $8 \mathrm{~mm}$ but varied in size up to $16-18 \mathrm{~mm}$. Other experimental data sets produced such specialized flakes between 4 and $20 \mathrm{~mm}$ (Henry et al. 1976; Gunn et al. 1976). Although we must be careful about placing undue credence in comparisons of experimental and archeological datasets, the concordance is striking and tantalizing and tends to support the above inferences that the unmodified debitage at the site was produced largely during late-stage biface and projectile point manufacture. The paucity of other flake types such as core rejuvenation flakes, uniface resharpening flakes, and bipolar flakes, coupled with the scarcity of cores, indicates that core reduction and the manufacture of other tool types were not common activities at this portion of the site or perhaps at the site in general. 


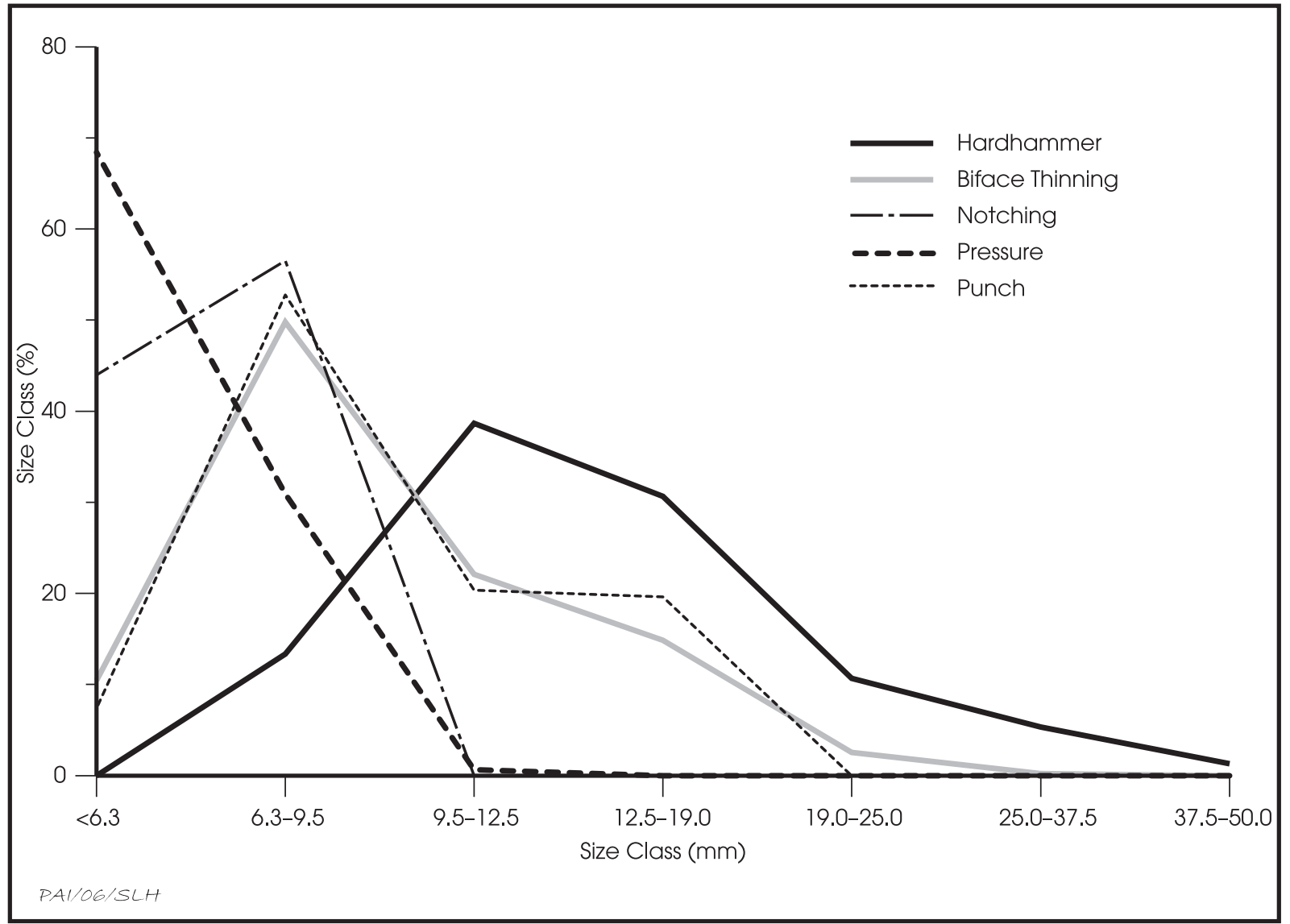

Figure 5.11. Size class distribution curves for various flake types.

\section{NONFEATURE BURNED ROCKS}

Excavations at 41CV1636 yielded varying amounts of burned rocks from nonfeature contexts. Burned rocks appear across the site, with the exception of several negative levels. A total of $178 \mathrm{~kg}$ of such material was removed from the four test units. Burned rocks were also observed consistently in all excavated backhoe trenches and in profiles. Weights from nonfeature proveniences ranged from less than $0.1 \mathrm{~kg}$ to $0.7 \mathrm{~kg}$.

\section{FAUNAL REMAINS}

Test excavations yielded 163 bone fragments. Bone was not generally common, the exception being Test Unit 3, which produced 49 fragments, mostly from Levels 9-12 (99.34$98.94 \mathrm{~m}$ ). A flotation sample from the western half of Feature 1 yielded an additional 16 small unidentifiable bone fragments. Additional flotation samples from Test Unit 3 yielded 3 small unidentifiable fragments from Level 7 and 79 fragments from Level $9(99.34-99.24 \mathrm{~m})$. In total, Test Unit 3 contained 146 pieces of bone. Test Unit 2 yielded up 7 fragments: 6 from Level 8 (99.29-99.19 $\mathrm{m}$ ) and 1 from Level 12 (98.89-98.79 m). Four bone fragments were recovered from manual excavations in Test Unit 1: 3 from Level 8 (99.42-99.32 $\mathrm{m})$ and 1 from Feature $2(99.29-99.09 \mathrm{~m})$. A flotation sample from Level 9 contained 2 small unidentifiable fragments. Test Unit 4 yielded the least amount of faunal material, with 2 fragments from Level 2 (100.25-100.15 m). The majority of specimens are small, fragmentary, and generally unidentifiable to order, genus, or species but appear to represent small to medium-sized mammals. Table 5.11 provides identifications 
Table 5.11. Summary of faunal remains from $41 \mathrm{CV} 1636$

\begin{tabular}{|c|c|c|c|c|c|c|}
\hline Test Unit & Lot \# & Level & $\begin{array}{l}\text { Depth } \\
\text { (cmbs) }\end{array}$ & Elevation & Specimen ID & $\begin{array}{c}\text { No. of } \\
\text { Fragments }\end{array}$ \\
\hline 1 & 14 & 8 & $70-80$ & $99.42-99.32$ & $\begin{array}{l}\text { Small vertebrate } \\
\text { fragments }\end{array}$ & 3 \\
\hline $\begin{array}{l}1 \\
(\text { Fea. } 2, \text { W } 1 / 2, \text { float \#6) }\end{array}$ & 19 & - & $83-99$ & $99 ; .29-99.17$ & Unidentifiable mammal & 1 \\
\hline 1 (NE Quad, float \#5) & & 9 & $80-90$ & $99.32-99.22$ & $\begin{array}{l}\text { Small mammal long bone } \\
\text { shaft fragments, burned }\end{array}$ & 2 \\
\hline 2 & 26 & 8 & $70-80$ & $99.29-99.19$ & $\begin{array}{l}2 \text { unidentifiable medium } \\
\text { mammal; } 4 \text { medium } \\
\text { mammal long bone shaft } \\
\text { fragments }\end{array}$ & 6 \\
\hline 2 & 27 & 9 & $80-90$ & $99.19-99.09$ & Unidentifiable mammal & 1 \\
\hline 2 & 30 & 12 & $110-120$ & $98.89-98.79$ & $\begin{array}{l}\text { Medium mammal long } \\
\text { bone shaft fragment } \\
\text { (burned black } 75 \% \text { ) }\end{array}$ & 1 \\
\hline 3 & 38 & 4 & $30-40$ & $99.84-99.74$ & Unidentifiable mammal & 1 \\
\hline $\begin{array}{l}3 \\
(\text { Fea. } 1, \mathrm{~W} 1 / 2, \text { float } \# 1)\end{array}$ & & 6 & $50-60$ & $99.64-99.55$ & $\begin{array}{l}\text { Unidentifiable small } \\
\text { vertebrate } \\
\text { fragments/splinters } \\
\end{array}$ & 16 \\
\hline $\begin{array}{l}3 \\
\text { (SW Quad, float \#2) }\end{array}$ & & 7 & $60-70$ & $99.54-99.44$ & $\begin{array}{l}\text { Unidentifiable vertebrate } \\
\text { fragments, burned }\end{array}$ & 3 \\
\hline 3 & 43 & 9 & $80-90$ & $99.34-99.24$ & $\begin{array}{l}6 \text { small mammal long bone } \\
\text { shaft fragments ( } 5 \\
\text { weathered white); } 1 \\
\text { unidentifiable mammal } \\
\text { (weathered white); } 3 \text { small } \\
\text { unidentifiable mammal } \\
\end{array}$ & 10 \\
\hline $\begin{array}{l}3 \\
\text { (SW Quad, float \#4) }\end{array}$ & & 9 & $80-90$ & $99.34-99.24$ & $\begin{array}{l}2 \text { small unidentifiable } \\
\text { mammal tooth fragments; } \\
1 \text { small mammal femoral } \\
\text { head; } 76 \text { mixed } \\
\text { splinters/shaft fragments } \\
\text { of small unidentifiable } \\
\text { mammal } \\
\end{array}$ & 79 \\
\hline 3 & 44 & 10 & $90-100$ & $99.24-99.14$ & $\begin{array}{l}1 \text { small mammal long one } \\
\text { shaft fragment; } 1 \text { small } \\
\text { unidentifiable mammal }\end{array}$ & 2 \\
\hline 3 & 45 & 11 & $100-110$ & $99.14-99.04$ & $\begin{array}{l}3 \text { unidentifiable mammal } \\
\text { (burned gray); } 4 \text { small } \\
\text { mammal long bone shaft } \\
\text { fragments ( } 2 \text { burned gray); } \\
2 \text { mammal rib shaft } \\
\text { fragments; } 7 \text { unidentifiable } \\
\text { mammal (unburned) }\end{array}$ & 16 \\
\hline 3 & 46 & 12 & $110-120$ & $99.04-98.94$ & $\begin{array}{l}13 \text { medium mammal long } \\
\text { bone shaft fragments; } 7 \\
\text { unidentifiable mammal }\end{array}$ & 20 \\
\hline 4 & 50 & 2 & $10-20$ & $100.25-100.15$ & $\begin{array}{l}\text { Unidentifiable medium } \\
\text { mammal }\end{array}$ & 2 \\
\hline
\end{tabular}


and provenience information of faunal material recovered from each test unit and from flotation samples. The relatively high percentage of bone fragments is probably due to natural taphonomic factors rather than human impacts such as marrow extraction or grease production, although these activities cannot be altogether ruled out. It is interesting that no fragments or elements identifiable as bison were recovered.

\section{MUSSEL SHELL AND RABDOTUS SP.}

Mussel shell fragments were common at 41CV1636, but due to postdepositional fragmentation and other taphonomic factors, only umbos and hinge teeth were counted $(n=18)$ and collected (Table 5.12). Scattered other fragments of mussel shell were observed during excavation but were highly fragmented, poorly preserved, and could not be identified to species. The recovered specimens may represent as few as 9 complete mussels or as many as 18 individuals. Almost one-third of the umbos or teeth are heated and burned ( $\mathrm{n}=5 ; 28$ percent), and this is probably a contributing factor to their fragmentary condition. Umbos or teeth were collected from Test Units 1, 2, 3, and 4 from Levels 2, 5, 6, 811 , and 12 (99.62-98.92 m). Recovered specimens tended to be present in or near levels containing relatively high artifact densities and generally absent in other levels.

Species represented are Lampsilis sp. $(\mathrm{n}=6)$, Amblema plicata $(\mathrm{n}=1)$, and Cyrtonaias tampicoensis $(\mathrm{n}=1)$. The remaining 10 specimens were too eroded or fragmentary to enable identification. All recovered specimens were probably used for subsistence, and none are modified. Each of these species is common for large and medium-sized stream systems and in a variety of substrates like sand, gravel, and mud in central Texas and adjacent regions and are not unexpected in the assemblage (Howells et al. 1996). The variety of species identified also indicates that the hydrologic character of Cowhouse Creek as a perennial stream has not changed.

Rabdotus sp. snail shells appeared frequently, but only whole shells were counted $(\mathrm{n}=315)$. Frequency of counted whole shells and observations of fragmentary specimens followed the vertical distribution of lithic artifacts and faunal remains, but it was not determined if snails were a food source at the site. The majority of Rabdotus sp. whole shells were observed in Test Unit 2 ( $\mathrm{n}=142,45$ percent). Lesser numbers of shells were observed in Test Unit $1(\mathrm{n}=72)$ and Test Unit $3(\mathrm{n}=97)$, but their presence in Test Unit 1, 2, and 3 corresponds to the presence and abundance of faunal material

Table 5.12. Summary of mussel shell umbos and hinge teeth recovered from $41 \mathrm{CV} 1636$

\begin{tabular}{|c|c|c|c|c|c|c|c|c|}
\hline $\begin{array}{l}\text { Test } \\
\text { Unit }\end{array}$ & Lot \# & Level & Feature & $\begin{array}{l}\text { Depth } \\
(\mathrm{cmbs})\end{array}$ & Elevation & Species & Condition & \# \\
\hline 1 & 11 & 5 & & $40-50$ & $99.72-99.62$ & Lampsilis sp. & & 1 \\
\hline 1 & 12 & 6 & & $50-60$ & $99.62-99.72$ & Unidentified & $\begin{array}{l}\text { fragmentary; } 1 \\
\text { burned }\end{array}$ & 3 \\
\hline 1 & 18 & 12 & & $110-120$ & 99.02-98.92 & $\begin{array}{l}\text { Cyrtonaias } \\
\text { tampicoensis }\end{array}$ & & 1 \\
\hline 2 & 23 & 5 & & $40-50$ & 99.59-99.49 & Lampsilis sp. & & 2 \\
\hline 2 & 26 & 8 & & $70-80$ & 99.29-99.19 & Lampsilis sp. & & 1 \\
\hline 2 & 29 & 11 & & $100-110$ & 98.99-98.89 & Amblema plicata & & 1 \\
\hline 2 & 30 & 12 & & $110-120$ & 98.89-98.79 & Lampsilis sp. & & 1 \\
\hline 2 & 30 & 12 & & $110-120$ & 98.89-98.79 & Unidentified & $\begin{array}{l}\text { fragmentary; } 2 \\
\text { burned }\end{array}$ & 3 \\
\hline 3 & 39 & 5 & & $40-50$ & 99.74-99.64 & Lampsilis sp. & burned & 1 \\
\hline 3 & 39 & 5 & & $40-50$ & $99.74-99.64$ & Unidentified & $\begin{array}{l}\text { fragmentary; } 1 \\
\text { burned }\end{array}$ & 2 \\
\hline 3 & 45 & 11 & & $100-110$ & 99.14-99.04 & Unidentified & $\begin{array}{l}\text { fragmentary, } \\
\text { eroded }\end{array}$ & 1 \\
\hline 4 & 50 & 2 & & $10-20$ & $100.25-100.15$ & Unidentified & $\begin{array}{l}\text { fragmentary, } \\
\text { eroded }\end{array}$ & 1 \\
\hline
\end{tabular}


and lithic artifacts. Test Unit 4, with the least amount of cultural material, also had the fewest snail shells ( $\mathrm{n}=4$ ). A few Rabdotus $\mathrm{sp}$. specimens were also recovered from flotation samples $(n=17)$.

\section{BOTANICAL REMAINS}

Very little botanical material was recovered from 41CV1636. Two charcoal samples were collected in situ from the eastern half of Feature 2 in Test Unit 1 . Charcoal sample 1 was collected at $99.21 \mathrm{~m}$ (91 cm below surface), and charcoal sample 2 was collected from 99.22 $\mathrm{m}$ (90 $\mathrm{cm}$ below surface). Both samples were subsequently submitted for radiocarbon dating but were deemed too small for dating after pretreatment. Charcoal fragments were also recovered from flotation samples collected from the same vicinity; small pieces were collected from Test Unit 1, Level $9(99.32-99.22 \mathrm{~m})$, and the western half of Feature 2 (99.29-99.17 m) but were subsequently deemed too small for radiocarbon dating. 



\section{INTERPRETATIONS AND RECOMMENDATIONS}

6

Archeological investigations at 41CV1636 revealed two cultural features and yielded 2,569 lithic artifacts (tools, cores, and unmodified debitage), 163 pieces of poorly preserved faunal bone, and 18 equally poorly preserved umbo and hinge tooth fragments of freshwater mussel shells. A series of flotation samples from feature and nonfeature contexts yielded a small number of whole Rabdotus sp. snail shells $(\mathrm{n}=17)$ and two small undatable fragments of charcoal. Excavations also produced 1,236 pieces ( $183 \mathrm{~kg}$ ) of burned rocks from feature and nonfeature contexts. Site deposits were encased within West Range alluvial and colluvial sediments that mantle the Fort Hood alluvium. Due to the absence of sufficient datable materials such as charcoal, data analysis focused on attempts to define arbitrary analysis units by sorting the features and recovered artifacts based on associations and spatial relationships.

The context of the recovered archeological materials appeared to represent a narrow time span (based on the presence of only two projectile point styles). This is quite uncharacteristic for the majority of Archaic sites in central Texas characterized by multiple dart point types and considerable evidence of multiple Archaic occupations. During excavation and later during artifact analysis, it was apparent that the site did not have sufficient integrity to define analytical units with meaningful contextual relationships. Thus, it was decided to treat the roughly $2 \mathrm{~m}$ of deposits as a single analytical unit. The presence of Provisional Type 1 and Pedernales points in the stratigraphic sequence at the site lends credence to this decision. The data suggest that the site included multiple overlapping occupations of variable length but all associated with the early portion of the Late Archaic period.

The primary occupation at $41 \mathrm{CV} 1636$ is consistent with interpretations as an early Late Archaic campsite situated within the T1 terrace along Cowhouse Creek. The majority of the cultural remains were excavated from Test Units 1, 2, and 3, with the abundance of material decreasing significantly in Test Unit 4. Fort Hood Provisional Type 1 points occurred in Test Units 1 and 2 stratigraphically beneath Pedernales points. The caveat to this is that Pedernales points occurred within Levels 5 and 6 in Test Unit 1 and Level 10 in Test Unit 2. Provisional Type 1 points were present in Level 7 in Test Unit 1 and Level 11 in Test Unit 2 . Because it was not possible to isolate discrete analysis units, the stratigraphic relationship between these units-and hence between the dart points-is not entirely clear. Both point styles appear to be mixed in the deposits.

Despite its chronological problems, the lithic assemblage from 41CV1636 presents a striking example of a site location where activities emphasized procurement and processing of limited resources, with a focus on hunting. The ratio of unmodified debitage to formal chipped tools (inclusive of artifacts previously recovered during the survey by McWilliams) is 183.42:1, and the ratio of projectile points to other formal chipped stone tools is 3.6:1. Earlier, Fields (1995) applied these and other measures of diversity to a series of sites in east central Texas to determine settlement strategies, land use intensity, and length of occupation. Fields determined that sites could be ranked into six different types on the basis of several key attributes of the lithic technology: ratio of unmodified debitage to formal chipped 
stone tools, a mean diversity index, ratio of projectile points to other formal chipped tools, ratios of ground or battered stone tools to unmodified debitage, and the ratio of flakes of other lithic types to flakes of unmodified debitage.

Procurement and processing locations with a strong focus on hunting were characterized by high unmodified debitage to formal tool ratios, low measures of diversity, very high projectile point to other formal tool ratios, and low or very low ratios of ground and battered stones and sandstone flakes to unmodified debitage (Fields 1995:105, 108). Diversity was measured by the Shannon diversity index (H'). Eleven artifact categories were used to measure diversity: projectile points, perforators, gouges, other bifaces, side scrapers, end scrapers, other unifaces, choppers, wedges, and modified flakes. The limited assemblage from 41CV1636 presented only three categories to measure assemblage diversity: projectile points, other bifaces, and modified flakes. The resulting diversity index value, although little more than heuristic for this site, is 1.41 - somewhat high when compared to the mean diversity index for sites with a hunting emphasis at Jewett Mine $(0.97 \pm 0.16)$ (Fields 1995:108). Assemblage size may be a biasing factor in the case of this site. However, the basic inference that hunting and procurement/processing activities were emphasized at $41 \mathrm{CV} 1636$ is still plausible on the basis of the character of the recovered assemblage.

Chronological inferences for site occupation based on projectile point typology are only somewhat clear, given the absence of any radiocarbon determinations. Pedernales dart points are associated with the Pedernales-Kinney interval of the middle Late Archaic period and follow the Bulverde style interval. Based on the projectile point styles represented at 41CV1636, it is difficult to determine if one or more temporally distinct components are represented.

At the Landslide site, Bulverde-like points comparable to Fort Hood Provisional Type 1 were recovered stratigraphically between Pedernales and Bell/Taylor but appear to be from the same time period as Nolan, Travis, and Bulverde (Kleinbach and Boyd 1999:340; Sorrow et al. 1967:14, 17). Similarly, identical points from the Evoe Terrace site were associated with Bulverde, Nolan, and Travis points.

Although the deposits at 41CV1636 could not be dated, similar point type occurrences documented from Fort Hood have been radiocarbon-dated and provide some indication when this site may have been occupied. Site 41CV1235 on Fort Hood yielded a series of seven Provisional Type 1 points from alluvial sediments along House Creek. Ages were determined by their association with radiocarbon dated hearths at the site (Kleinbach and Boyd 1999:337-338). At 41CV1269, a Provisional Type 1 point was retrieved from alluvial deposits in Test Unit 3 below a Travis point. Charcoal recovered from a hearth in this test unit yielded a radiocarbon date of 2205-2040 B.C. (Kleinbach and Boyd 1999:336). This date provides a minimum age for the point. One specimen was recovered from Analysis Unit 1 at 41CV1235 near the base of a thick burned rock midden feature radiocarbon dated to 2400-2205 B.C. Six Provisional Type 1 points from Analysis Unit 2 were recovered from Levels 7 through 9 in two contiguous test units. Hearth charcoal from Level 11 was radiocarbon dated to 3335-3070 B.C. and demonstrates that all six points are younger than this date. In addition, two other radiocarbon dates on hearth charcoal from the same levels as the points are 2865-2585 B.C. (Feature 5) and 2400-2205 B.C. (Feature 1). The context of the points and the dated charcoal indicate that Provisional Type 1 points are bracketed between 3000 and 2000 B.C. At 41CV1235, the upper portion of the Feature 1 midden yielded one Montell and two Pedernales points in contexts above Provisional Type 1 dart points. Kleinbach and Boyd (1999:343-344) provide additional contextual and morphological comparisons between Provisional Type 1 points from several sites within central Texas. The conclusion regarding this point type is that it represents a definite "coherent morphological class" occurring within the Bulverde interval (ca. 4000-3300 в.P.) and perhaps a bit earlier during the Nolan-Travis interval (ca. 5500-4000 в.P.). A similar time interval of occupation is also postulated for 41CV1636.

Temporally, dart points morphologically similar to Johnson's Bulverde Variety 2 having long and narrow stems based on earlier research from Stillhouse Hollow (Sorrow et al. 1967: 14-17) and the Wunderlich site (41CM3) (Johnson 1962:19-20) were recovered from Stratum 4 of the Youngsport site. From 41CV1636, the two fragmentary specimens recovered during current NRHP testing and an earlier specimen recovered during survey (McWilliams 
and Kibler 2006) fit the stem characteristics associated with Bulverde Variety 2 . The wider and shorter stemmed Variety 1 Bulverde points were suspected of being earlier and occurring with Pedernales points at the Youngsport site (Shafer 1963:62). Pedernales points were considered the typical point type for the Round Rock phase (Prewitt 1981:80). Within the Late Archaic of central Texas, Johnson and Goode (1994:29) speculated that the Bulverde type may have been intrusive onto the eastern Edwards Plateau from the prairie settings to the north and northeast. Presumably this regional connection is made based on stem similarities between Bulverde and earlier Calf Creek points. Regardless, Johnson and Goode (1994:29) see this dart point style as representative of the inception of the Late Archaic I subperiod at ca. 2300 B.C.

The low diversity of raw materials, low assemblage diversity among tool types, and the focused nature of the unmodified debitage all argue for an occupation or occupations of short duration and limited function. Technologically the lithic assemblage reflects the discard and replacement of broken or otherwise worn-out dart points. The recovered unmodified debitage assemblage exhibits the character of an assemblage produced during late-stage biface finishing and various stages of dart point manufacture (such as notching and final shaping). Flake types indicate that a variety of techniques were employed in the manufacture of bifaces and dart points: pressure, notching, occasional hardhammer percussion, softhammer percussion, and indirect percussion. Indirect percussion was not used to completely manufacture bifaces but was employed to solve knapping problems and as necessary in other stages of the flaking process. The presence of a few edge-modified flakes and fragments indicate that activities possibly related to subsistence were occurring at the site. Certainly the presence of two burned rock features indicates subsistence-related tasks were being conducted.

The Bull Pen site (41BP280) in Bastrop County (Ensor and Mueller-Wille 1988), 41MM340 in Milam County (Mahoney et al. 2003), and the Anthon site (41UV60) in Uvalde County (Goode 2002) have aspects of their lithic assemblages that can be compared to 41CV1636. Site 41MM340, Anthon, and Bull Pen sites represent what may be considered the opposite end of the spectrum from 41CV1636. Where the lithic assemblage from
41CV1636 has a dearth of preforms and fragments and a number of discarded and broken Pedernales points, these sites have abundant evidence for the manufacture and use of Pedernales points. However, the biface fragments from 41CV1636 compare favorably in morphology and technology to complete and incomplete bifaces and dart point preforms from Anthon and Bull Pen. This suggests that the distal biface fragments at 41CV1636 probably represent discards from dart point manufacture. Archeological and experimental debitage studies from the Bull Pen site broadly supports an interpretation of 41CV1636 assemblage emphasizing the late-stage finishing of bifaces and dart point preforms, the distinct possibility being that Pedernales points were being completed, albeit in low numbers. At Anthon, Bull Pen, and 41MM340, large ovate bifaces appear to have served as preforms for the manufacture of Pedernales points. Based on debitage analysis, all that can really be said for $41 \mathrm{CV} 1636$ is that large middle- to late-stage bifaces were being finished. Sizes of notching flakes indicate that large corner-notched points were being made.

For the Anthon site, Goode (2002:50) noted that there were no positively identified Pedernales manufacturing failures in the assemblage. Although the assemblage is replete with Pedernales points, the assumption is that there was a high level of success in the completion of these points. One could also infer that bifacial preforms destined for finishing into Pedernales forms were not notched/shouldered until the final finishing stages as is possibly represented at $41 \mathrm{CV} 1636$. There are also no manufacturing failures at this site. Unfinished Pedernales points recovered from the Bull Pen site indicate that the notching/shouldering of large ovate bifaces occurred very late in the manufacture sequence. It is inferred that similar late-stage large ovate bifaces formed part of the overall tool kit at 41CV1636.

In their effort to place Pedernales points from 41MM340 into regional perspective, Tomka and others (2003:134-144) employed comparative data from other localities. Regional data from sites in southwest central Texas and east central Texas was used to identify five distinct stem forms with variable blade shapes. A Southern Edwards Plateau Group and a Central and EastCentral Texas Group were defined. Stem forms 1 and 5 were more common on the Central and 
East-Central Texas groups, while stem forms 2,3 , and 4 were more characteristic of sites in the Southern Edwards Plateau. The majority of Pedernales points from 41MM340 were assigned to stem form 5 characterized by a contracting stem with straight stem edges, sharp to rounded stem corners, and weak to moderately indented base (Tomka et al. 2003:134). This stem form is reminiscent of the stem morphology of some specimens from 41CV1636. Points from $41 \mathrm{CV} 1636$ and 41MM340 resemble Variety 3 and 4 from the Anthon site (Goode 2002). An exception is the presence of two Pedernales points from 41CV1636 that resemble stem forms 2, 4, and 6 characteristic of examples from the Southern Edwards Plateau. These stem forms were entirely lacking at 41MM340. The assemblage from 41MM340 also included Pedernales preforms emphasizing manufacture of the stem prior to completion of the blade.

Chipped stone raw material characteristics indicate little use of cherts or other suitable material that may have been accessible within the channel of Cowhouse Creek in the vicinity of the site. The apparent emphasis on biface technology coincides with the nonuse of local chert gravels since bedload materials typically can be highly fractured and comminuted, hence unsuitable for biface manufacture. There is little direct indication that raw materials from farther southeast (i.e., from Fort Hood) were being brought to the site and flaked. A dearth of cortical debris and hardhammer percussion flakes bears witness that the majority of raw material at the site was arriving in a semireduced or much-reduced form, presumably as middle- or late-stage (unnotched) bifaces. Raw materials at the site primarily represent cherts occurring as unweathered or slightly weathered nodules based on the limited cortex data available. The limited amount of cortex suggests that some of the middle-stage bifaces may have not been entirely cortex free or that cortex-bearing macroflakes removed from cores elsewhere either on or off site were also being brought to this part of 41CV1636. The majority of materials identified bear resemblance to undifferentiated cherts from the Edwards Formation, easily available within $20 \mathrm{~km}$ of the site. Currently, the patterns of raw material procurement at
41CV1636 do not appear to have included chert sources associated with known locations within the Fort Hood range.

\section{ASSESSMENT AND RECOMMENDATIONS}

Test excavations at 41CV1636 yielded moderate densities of lithic artifacts, including eight dart points, two burned rock features, and a small number of modified flake tools. Feature 1 appears to be an intact rock-lined pit. Feature 2 lacks the same level of integrity and may be a pile of burned and unburned rocks or an otherwise disturbed feature. Bone and shell were uncommon and poorly preserved. Cultural material was vertically distributed within a ca. 100-cm-thick deposit.

The cultural materials recovered from testing do, however, provide some insights into the use of Pedernales and Provisional Type I dart points and the composition of individual tool kits on this portion of the Lampasas Cut Plain. Also of significance, the lithic assemblage also provides some interesting technological and behavioral information regarding biface production and the use of multiple flaking techniques during manufacture. For these reasons, the lithic assemblage from 41CV1636 may provide significant comparative data for future analyses of chipped stone tool assemblages from similar small sites in upland settings located on the Lampasas Cut Plain.

The context of the archeological deposits and the probable narrow temporal span based on projectile point styles and relative homogeneity in debitage is intriguing. However, the poor preservation of organic remains was a hindrance to more accurate dating. Two recovered charcoal samples were too small to provide radiocarbon dates, and in all probability additional work would not result in more appropriate samples. Poor preservation of faunal and other organic materials also prevents more detailed interpretations of subsistence and onsite activities. It is recommended that $41 \mathrm{CV} 1636$ be considered ineligible for listing in the National Register of Historic Places or designation as a State Archeological Landmark. No further work is recommended to be conducted at 41CV1636. 


\section{REFERENCES CITED}

Abbott, James T.

1994 Natural Environment. In Archeological Investigations on 571 Prehistoric Sites at Fort Hood, Bell and Coryell Counties, Texas, edited by W. Nicholas Trierweiler, pp. 7-38. Archeological Resource Management Series, Research Report No. 31. United States Army, Fort Hood.

Abbott, James T., and Marybeth Tomka

1995 Lithic Analysis. In NRHP Significance Testing of 57 Prehistoric Archeological Sites on Fort Hood, Texas, edited by James T. Abbott and W. Nicholas Trierweiler, pp. 679-764. Archeological Resource Management Series, Research Report No. 34. United States Army, Fort Hood.

Abbott, James T., and W. Nicholas Trierweiler (editors)

1995 NRHP Significance Testing of 57 Prehistoric Archeological Sites on Fort Hood, Texas: Volumes I and II. Archeological Resource Management Series, Research Report No. 34 United States Army, Fort Hood.

Andrefsky, William, Jr.

2000 Lithics:Macroscopic Approaches to Analysis. Cambridge University Press, Cambridge.

Arnn, III, John W., Douglas K. Boyd, and Karl W. Kibler

2000 Archeological Testing and Reassessment of 41CV1423, Coryell County, Fort Hood, Texas. Archeological Resource Management Series, Research Report No. 40. United States Army, Fort Hood.

Banks, Larry D.

1990 From Mountain Peaks to Alligator Stomachs: A Review of Lithic Sources in the TransMississippi South, the Southern Plains, and Adjacent Southwest. Oklahoma Anthropological Society Memoir No. 4. Norman, Oklahoma.

Black, Stephen L.

1989 Central Texas Plateau Prairie. In From the Gulf to the Rio Grande: Human Adaptations in Central, South, and Lower Pecos, Texas, by Thomas R. Hester, Stephen L. Black, D. Gentry Steele, Ben W. Olive, Anne A. Fox, Karl J. Reinhard, and Leland C. Bement, pp. 5-38.
Research Series 33. Arkansas Archeological Survey, Fayetteville.

Black, Stephen L., Linda W. Ellis, Darrel G. Creel, and Glenn T. Goode

1997 Hot Rock Cooking on the Greater Edwards Plateau: Four Burned Rock Midden Sites in West Central Texas. 2 vols. Studies in Archeology 22, Texas Archeological Research Laboratory, The University of Texas at Austin. Report 2. Archeology Studies Program, Texas Department of Transportation, Austin.

Blair, W. Frank

1950 The Biotic Provinces of Texas. The Texas Journal of Science 2(1):93-117.

Bolton, Herbert E.

1915 Texas in the Middle Eighteenth Century. University of Texas Press, Austin.

Bordes, Francois, and D. E. Crabtree

1969 The Corbiac Blade Technique and Other Experiments. Tebiwa 12:1-22.

Bousman, C. Britt

2005 Coping With Risk: Later Stone Age Technological Strategies at Blydefontein Rock Shelter, South Africa. Journal of Anthropological Archaeology 24: 193-226.

Boyd, Douglas K.

1999 Fort Hood Chert Typology: Analysis of House Creek Chert Samples and Replicability Tests. In National Register Testing of 42 Prehistoric Archeological Sites on Fort Hood, Texas: The 1996 Season, by Karl Kleinbach, Gemma Mehalchick, Douglas K. Boyd, and Karl W. Kibler, pp. 363-380. Archeological Resources Management Series, Research Report No. 38. United States Army, Fort Hood.

Bradbury, Andrew P., and Philip J. Carr

1999 Examining Stage and Continuum Models of Flake Debris Analysis: An Experimental Approach. Journal of Archaeological Science 26:105-116.

Bryant, Vaughn R., and Richard G. Holloway

1985 The Late Quaternary Paleoenvironmental Record of Texas. In Pollen Records of Late 
Quaternary North American Sediments, edited by Vaughn M. Bryant and Richard G. Holloway, pp. 39-70. American Association of Stratigraphic Palynologists.

Bureau of Economic Geology

1970 The Geologic Atlas of Texas, Waco Sheet. Bureau of Economic Geology, The University of Texas at Austin.

1976 The Geologic Atlas of Texas, Brownwood Sheet Bureau of Economic Geology, The University of Texas at Austin.

Callister, Kathleen, Jay Peck, and J. Michael Quigg

1994 Analysis of and Variation in Fort Hood Projectile Points. In Archeological Investigations on 571 Prehistoric Sites at Fort Hood, Bell and Coryell Counties, Texas, edited by W. Nicholas Trierweiler, pp. 275-348. Archeological Resource Management Series, Research Report No. 31. United States Army, Fort Hood.

Campbell, Thomas N

1988 Indians of Southern Texas and Northeastern Mexico: Selected Writings of Thomas Nolan Campbell. Texas Archeological Research Laboratory, The University of Texas at Austin.

Campbell, T. N. and T. J. Campbell

1981 Historic Indian Groups of the Choke Canyon Reservoir and Surrounding Area, Southern Texas. Choke Canyon Series 1. Center for Archaeological Research, The University of Texas at San Antonio.

Cliff, Maynard B.

2002 National Register Testing Conducted at Site 41CV1630, Coryell County, Texas. Archeological Studies Program Report No. 37. Environmental Affairs Division, Texas Department of Transportation, Austin.

Collins, Michael B.

1990 The Archaeological Sequence of Kincaid Rockshelter, Uvalde County, Texas. Transactions of the Twenty-Fifth Regional Archeological Symposium for Southeastern New Mexico and Western Texas, pp. 25-34.

1995 Forty Years of Archeology in Central Texas. Bulletin of the Texas Archeological Society 66:361-400.

Collins, Michael B., Bruce Ellis, and Cathy Dodt-Ellis

1990 Excavations at the Camp Pearl Wheat Site (41KR243): An Early Archaic Campsite on Town Creek, Kerr County, Texas. Studies in Archeology 6. Texas Archeological Research Laboratory, The University of Texas at Austin.

Collins, Michael B., Thomas R. Hester, and Pamela J. Headrick

1992 Engraved Cobbles from the Gault Site, Central Texas. Current Research in the Pleistocene 9:3-4.

Cotterell, Brian, and Johan Kamminga

1987 The Formation of Flakes. American Antiquity 52(4):675-708.
Crabtree, Don E.

1982 An Introduction to Flintworking. Occasional Papers of the Idaho Museum of Natural History No. 28. Pocatello, Idaho.

Dickens, William A.

1993a Lithic Analysis. In Archaeological Investigations in Bull Branch: Results of the 1990 Summer Archaeological Field School, edited by D. L. Carlson, pp. 79-115. Archaeological Resources Management Series, Research Report No. 19. United States Army, Fort Hood.

1993b Lithic Artifact Analysis. In Archaeological Investigations in Spicewood Creek: Results of the 1991 Summer Archaeological Field School, edited by D. L. Carlson, pp. 75-111. Archaeological Resource Management Series, Research Report No. 22. United States Army, Fort Hood.

Ellis, G. Lain, Charles D. Frederick, James T. Abbott, and Marybeth S. F. Tomka

1995 Analytical Methods. In NRHP Testing of 57 Prehistoric Archeological Sites on Fort Hood Texas, edited by James T. Abbott and W. Nicholas Trierweiler, pp. 56-71. Archeological Resource Management Series, Research Report No. 34. United States Army, Fort Hood.

Ellis, G. Lain, C. Lintz, W. N. Trierweiler, and J. M. Jackson

1994 Significance Standards for Prehistoric Cultural Resources: A Case Study from Fort Hood, Texas. USACERL Technical Report CRC-94/04. United States Army Corps of Engineers, Construction Engineering Research Laboratories, Urbana, Illinois.

Ensor, H. Blaine, and Catherine S. Mueller-Wille

1988 Excavations at the Bull Pen Site 41BP280, Colorado River Drainage, Bastrop County, Texas. Contract Reports in Archaeology, Report No. 3. State Department of Highways and Public Transportation, Highway Design Division, Austin

Fenneman, Nevin M.

1938 Physiography of the Eastern United States. McGraw-Hill, New York.

Fields, Ross C.

1995 Hunter-Gatherer Settlement Strategies in the Oak Woodlands of East-Central Texas. In Advances in Texas Archeology, Volume I: Contributions from Cultural Resource Management, edited by James E. Bruseth and Timothy K. Perttula, pp. 81-130. Cultural Resource Management Report 5. Department of Antiquities Protection, Texas Historical Commission, Austin.

Fox, Daniel E.

1979 The Lithic Artifacts of Indians at the Spanish Colonial Missions, San Antonio, Texas. Special Report No. 8. Center for Archaeological Research, The University of Texas at San Antonio. 
Frederick, Charles D., Michael D. Glascock, Hector Neff, and Christopher M. Stevenson.

1994 Evaluation of Chert Patination as a Dating Technique: A Case Study from Fort Hood, Texas. Archeological Resource Management Series, Research Report No. 32. United States Army, Fort Hood.

Frederick, Charles D., and Christopher Ringstaff

1994 Lithic Resources at Fort Hood: Further Investigation. In Archaeological Investigations on 571 Prehistoric Sites at Fort Hood, Bell and Coryell Counties, Texas, edited by W. Nicholas Trierweiler, pp. 125-181. Archeological Resource Management Series, Research Report No. 31. United States Army, Fort Hood.

Frison, George C., and Bruce A. Bradley

1980 Folsom Tools and Technology at the Hanson Site, Wyoming. University of New Mexico Press, Albuquerque.

Goode, Glenn T.

1988 Appendix V: 41BP280 (Bull Pen Site) Lithic Replication Study. In Excavations at the Bull Pen Site 41BP280, Colorado River Drainage, Bastrop County, Texas, by H. Blaine Ensor and Catherine S. Mueller-Wille, pp. 321-330. Contract Reports in Archaeology, Report No. 3. State Department of Highways and Public Transportation, Highway Design Division, Austin.

1991 Late Prehistoric Burned Rock Middens in Central Texas. In The Burned Rock Middens of Texas: An Archeological Symposium, edited by T. R. Hester, pp. 71-92. Studies in Archeology 13. Texas Archeological Research Laboratory, The University of Texas at Austin.

2002 The Anthon Site:APrehistoric Encampment in Southern Uvalde County, Texas. Archeological Studies Program Report 38. Environmental Affairs Division, Texas Department of Transportation, Austin.

Gunn, Joel, and Royce Mahula

1977 Sollberger Distributions: Functional Areas of the Site. In Hop Hill: Culture and Climatic Change in Central Texas, by Joel Gunn and Royce Mahula, pp. 137-147. Special Report No. 5. Center for Archaeological Research, The University of Texas at San Antonio.

Gunn, Joel, Royce Mahula, and J. B. Sollberger

1976 The Sollberger Distribution-Analysis and Application of a Tool Reduction Sequence. $L a$ Tierra 3(4):2-8.

Hayward, O. T., P. M. Allen, and D. L. Amsbury

1996 Lampasas Cut Plain: Episodic Development of an Ancient and Complex Regional Landscape, Central Texas. In Guidebook to Upland, Lowland, and In Between-Landscapes in the Lampasas Cut Plain, edited by David L. Carlson, pp. 1-1 through 1-97. Friends of the Pleistocene South-Central Cell 1996 Field Trip. Department of Anthropology, Texas A\&M University, College Station, and Department of Geology, Baylor University, Waco.
Henry, Donald O., C. Vance Haynes, and Bruce Bradley 1976 Quantitative Variations in Flaked Stone Debitage. Plains Anthropologist 21(71):57-61.

Henry, Donald O., Foster E. Kirby, Anne B. Justen, and Thomas R. Hays

1980 The Prehistory of Hog Creek: An Archaeological Investigation of Bosque and Coryell Counties, Texas. Department of Anthropology, Laboratory of Anthropology, University of Tulsa, Oklahoma.

Hester, Thomas R.

1989 Historic Native American Populations. In From the Gulf to the Rio Grande: Human Adaptation in Central, South, and Lower Pecos, Texas, by Thomas R. Hester, Stephen L. Black, D. Gentry Steele, Ben W. Olive, Anne A Fox, Karl J. Reinhard, and Leland C. Bement, pp. 77-84. Research Series 33. Arkansas Archeological Survey, Fayetteville.

Hill, Robert T.

1901 Geography and Geology of the Grand and Black Prairies, Texas. Twenty-First Annual Report, Part VII:666. United States Geological Survey, Washington, D.C.

Holmes, Amy M.

2001 Archeological Survey with Geoarcheological Evaluation on SH 36 at the Leon River, Coryell County, Texas. Letter Report No. 469. Prewitt and Associates, Inc., Austin.

Howells, R. G., R. W. Neck, and H. D. Murray

1996 Freshwater Mussels of Texas. Texas Parks and Wildlife Press, Austin.

Huebner, Jeffrey A.

1991 Late Prehistoric Bison Populations in Central and South Texas. Plains Anthropologist 36(137):343-358.

Inizan, Marie-Louise, Helene Roche, and Jacques Tixier

1992 Technology of Knapped Stone. Prehistoire de la Pierre Tailee, Tome 3. Cercle de Recherches et d'Etudes Prehistoriques, Centre National de la Recherche Scientifique. Meudon, France.

Jelks, Edward B.

1962 The Kyle Site: A Stratified Central Texas Aspect Site in Hill County, Texas. Archeology Series No. 5. Department of Anthropology, The University of Texas at Austin.

Johnson, LeRoy

1962 Wunderlich: A Burned-Rock Midden Site. In Salvage Archeology of Canyon Reservoir: The Wunderlich, Footbridge, and Oblate Sites, by LeRoy Johnson, Dee Ann Suhm, and Curtis D. Tunnell, pp. 13-48. Texas Memorial Museum Bulletin No. 5. The University of Texas at Austin.

1995 Past Cultures and Climates at Jonas Terrace, 41ME29, Medina County, Texas. Office of the State Archeologist Report 40. Texas Department of Transportation and Texas Historical Commission, Austin. 
Johnson, LeRoy, and Glenn T. Goode

1994 A New Try at Dating and Characterizing Holocene Climates, as Well as Archeological Periods, on the Eastern Edwards Plateau. Bulletin of the Texas Archeological Society 65:1-51.

Kibler, Karl W., and Douglas K. Boyd

1999 Archeological Background and Research Contexts. In National Register Testing of 42 Prehistoric Archeological Sites on Fort Hood, Texas: The 1996 Season, pp. 13-18, by Karl Kleinbach, Gemma Mehalchick, Douglas K. Boyd, and Karl W. Kibler. Research Report No. 38. Archeological Resource Management Series, United States Army, Fort Hood.

Kleinbach, Karl, and Douglas K. Boyd

1999 Analysis of Materials Recovered. In National Register Testing of 42 Prehistoric Sites on Fort Hood, Texas: The 1996 Season, by Karl Kleinbach, Gemma Mehalchick, Douglas K. Boyd, and Karl W. Kibler, pp. 325-362. Archeological Resource Management Series, Research Report No. 38. United States Army, Fort Hood.

Kleinbach, Karl, Gemma Mehalchick, James T. Abbott, and J. Michael Quigg

1995 Burned Rock Mounds, Middens, Concentrations, and Pavements. In NRHP Significance Testing of 57 Prehistoric Archeological Sites on Fort Hood, Texas, Volume II, edited by James T. Abbott and W. Nicholas Trierweiler, pp. 765-801. Archeological Resource Management Series, Research Report No. 34. United States Army, Fort Hood.

Kleinbach, Karl, Gemma Mehalchick, Douglas K. Boyd, and Karl W. Kibler

1999 National Register Testing of 42 Prehistoric Sites on Fort Hood, Texas: The 1996 Season. Archeological Resource Management Series, Research Report No. 38. United States Army, Fort Hood.

Mahoney, Richard B., Steve A. Tomka, Raymond P. Mauldin, Harry J. Shafer, Lee C. Nordt, Russel D. Greaves, and Rebecca R. Galdeano

2003 Data Recovery Excavations at 41MM340: A Late Archaic Site along Little River in $\mathrm{Mi}$ lam County, Texas. Archaeological Survey Report No. 340. Center for Archaeological Research, The University of Texas at San Antonio. Archeological Studies Program Report No. 54. Environmental Affairs Division, Texas Department of Transportation, Austin.

Masson, Marilyn A.

1998 Analysis of Debitage. In Wilson-Leonard: An 11,000-year Archeological Record of Hunter-Gatherers in Central Texas. Volume III: Artifacts and Special Studies, edited by Michael B. Collins, pp. 683-702. Studies in Archeology 31. Texas Archeological Research Laboratory, The University of Texas at Austin. Report 10. Archeology Studies Program, Environmental Affairs Division, Texas Department of Transportation, Austin.
Masson, Marilyn A., and Michael B. Collins

1995 The Wilson-Leonard Site (41WM235). Cultural Resource Management News \& Views 7(1):6-10. Texas Historical Commission, Austin.

McCaleb, Nathan L.

1985 Soil Survey of Coryell County, Texas. United States Department of Agriculture, Soil Conservation Service, in cooperation with the Texas Agricultural Experiment Station and United States Department of the Army, Fort Hood, Texas.

McKinney, Wilson W.

1981 Early Holocene Adaptations in Central and Southwestern Texas: The Problem of the Paleoindian-Archaic Transition. Bulletin of the Texas Archeological Society 52:91-120.

McWilliams, Jennifer K.

2005 Archeological Survey for Widening of a Segment of U.S. Highway 84, Coryell County, Texas. Letter Report No. 723. Prewitt and Associates, Inc., Austin.

McWilliams, Jennifer K., and Karl W. Kibler

2006 Interim Report on Test Excavations at 41CV1636, Coryell County, Texas. Prewitt and Associates, Inc., Austin.

Mehalchick, Gemma, Kyle Killian, Karl W. Kibler, and Douglas K. Boyd

2002 Geoarcheological Investigations at the Clear Creek Golf Course Site (41CV413), Fort Hood, Texas. Archeological Resource Management Series, Research Report No. 46. United States Army, Fort Hood.

Mehalchick, Gemma, Karl Kleinbach, Douglas K. Boyd, Steve A. Tomka, and Karl W. Kibler

1999 National Register Testing of 19 Prehistoric Archeological Sites at Fort Hood, Texas: The 1995 Season. Archeological Resource Management Series, Research Report No. 37. United States Army, Fort Hood.

Miller, E. O., and Edward B. Jelks

1952 Archeological Investigations at the Belton Reservoir, Coryell County, Texas. Bulletin of the Texas Archeological and Paleontological Society 23:168-217.

Natural Fibers Information Center

1987 The Climates of Texas Counties. Bureau of Business Research, The University of Texas at Austin, in cooperation with the Office of the State Climatologist, Texas A\&M University, College Station.

Newcomb, W. W., Jr.

1961 The Indians of Texas. The University of Texas Press, Austin.

Nordt, Lee C.

1992 Archaeological Geology of the Fort Hood Military Reservation, Ft. Hood, Texas. Archaeological Resource Management Series, Research Report No. 25. United States Army, Fort Hood. 
Nordt, Lee C., Thomas W. Boutton, Charles T. Hallmark, and Michael R. Waters

1994 Late Quaternary Vegetation and Climate Changes in Central Texas Based on the Isotopic Composition of Organic Carbon. Quaternary Research 41(1):109-120.

Patterson, L. W., and J. B. Sollberger

1978 Replication and Classification of Small Size Lithic Debitage. Plains Anthropologist 23(80):103-112.

Prewitt, Elton R.

1974 Archeological Investigations at the Loeve-Fox Site, Williamson County, Texas. Research Report No. 49. Texas Archeological Survey, Austin.

1981 Cultural Chronology in Central Texas. Bulletin of the Texas Archeological Society 52:65-89.

1985 From Circleville to Toyah: Comments on Central Texas Chronology. Bulletin of the Texas Archeological Society 54:201-238.

Riskind, David H., and David D. Diamond

1986 Plant Communities of the Edwards Plateau of Texas: An Overview Emphasizing the Balcones Escarpment Zone Between San Antonio and Austin with Special Attention to Landscape Contrasts and Natural Diversity. In The Balcones Escarpment: Geology, Hydrology, Ecology and Social Development in Central Texas, pp. 21-34, edited by Patrick L. Abbott and C. M. Woodruff, Jr. Geological Society of America, San Diego.

Shafer, Harry J.

1963 Test Excavations at the Youngsport Site: A Stratified Terrace Site in Bell County, Texas. Bulletin of the Texas Archeological Society 34:57-81.

Shafer, Harry J., Dee Ann Suhm, and J. Dan Scurlock 1964 An Investigation and Appraisal of the Archeological Resources of Belton Reservoir, Bell and Coryell Counties, Texas: 1962. Miscellaneous Papers No. 1, Texas Archeological Salvage Project, Austin.

Sorrow, William M., Harry J. Shafer, and Richard E. Ross

1967 Excavations at Stillhouse Hollow Reservoir. Papers of the Texas Archeological Salvage Project No. 11. Austin.

Story, Dee Ann

1985 Adaptive Strategies of Archaic Cultures of the West Gulf Coastal Plain. In Prehistoric Food Production in North America, edited by R. I. Ford, pp. 19-56. Anthropological Papers 75. Museum of Anthropology, University of Michigan, Ann Arbor.

Suhm, Dee Ann, and Edward B. Jelks (editors)

1962 Handbook of Texas Archeology: Type Descriptions. Texas Archeological Society Special Publication No. 1 and Texas Memorial Museum Bulletin No. 4. Austin, Texas.
Tharp, Benjamin C.

1939 The Vegetation of Texas. Texas Academy of Science Publications in Natural History. Anson Jones Press, Houston.

Titmus, Gene

1985 Some Aspects of Stone Tool Notching. In Stone Tool Analysis: Essays in Honor of Don E. Crabtree, edited by Mark G. Plew, James C. Woods, and Max G. Pavesic, pp. 243-264. University of New Mexico Press, Albuquerque.

Tomka, Steve A., Harry J. Shafer, and Raymond P. Mauldin

2003 Lithic Technology at 41MM340. In Data Recovery Excavations at 41MM340: A Late Archaic Site Along Little River in Milam County, Texas, by Richard B. Mahoney, Steve A. Tomka, Raymond P. Mauldin, Harry J. Shafer, Lee C. Nordt, Russell D. Greaves, and Rebecca R. Galdeano, pp. 133-154. Archaeological Survey Report, No. 340. Center for Archaeological Research, The University of Texas at San Antonio. Report No. 54. Archeological Studies Program, Environmental Affairs Division, Texas Department of Transportation, Austin.

Toomey, Rickard S., III, Michael D. Blum, and Salvatore Valastro, Jr.

1993 Late Quaternary Climates and Environments of the Edwards Plateau. Global and Planetary Change 7:299-320.

Trierweiler, W. Nicholas (editor)

1994 Archeological Investigations on 571 Prehistoric Sites at Fort Hood, Bell and Coryell Counties, Texas. Archeological Resource Management Series, Research Report No. 31. United States Army, Fort Hood.

1995 Introduction. In NRHP Significance Testing of 57 Prehistoric Archeological Sites on Fort Hood, Texas, Volume I, edited by James T. Abbott and W. Nicholas Trierweiler, pp. 1-25. Archeological Resource Management Series, Research Report No. 34. United States Army, Fort Hood.

Turner, Ellen Sue, and Thomas R. Hester

1993 A Field Guide to Stone Artifacts of Texas Indians. 2nd edition. Gulf Publishing Company, Houston.

Turpin, Solvieg A., Leland C. Bement, and David G. Robinson

1992 All American Pipeline Project: Final Status Report. Texas Archeological Research Laboratory, The University of Texas at Austin, and Texas Historical Commission, Austin.

Weber, Cary

1994 A Replication Technique for Andice/Bell Points. In Archaic and Late Prehistoric Human Ecology in the Middle Onion Creek Valley, Hays County, Texas, by Robert A. Ricklis and Michael B. Collins, pp. 629-651. Studies in Archeology 19, Texas Archeological Research Laboratory, The University of Texas at Austin. 
Weir, Frank A.

1976 The Central Texas Archaic. Unpublished Ph.D. dissertation, Department of Anthropology, Washington State University, Pullman.

Whittaker, John C.

1994 Flintknapping: Making and Understanding Stone Tools. University of Texas Press, Austin.
Willey, Gordon R., and Philip Phillips

1958 Method and Theory in American Archaeology. University of Chicago Press, Chicago. 


\section{APPENDIX: Provenience Data for Artifacts Recovered}





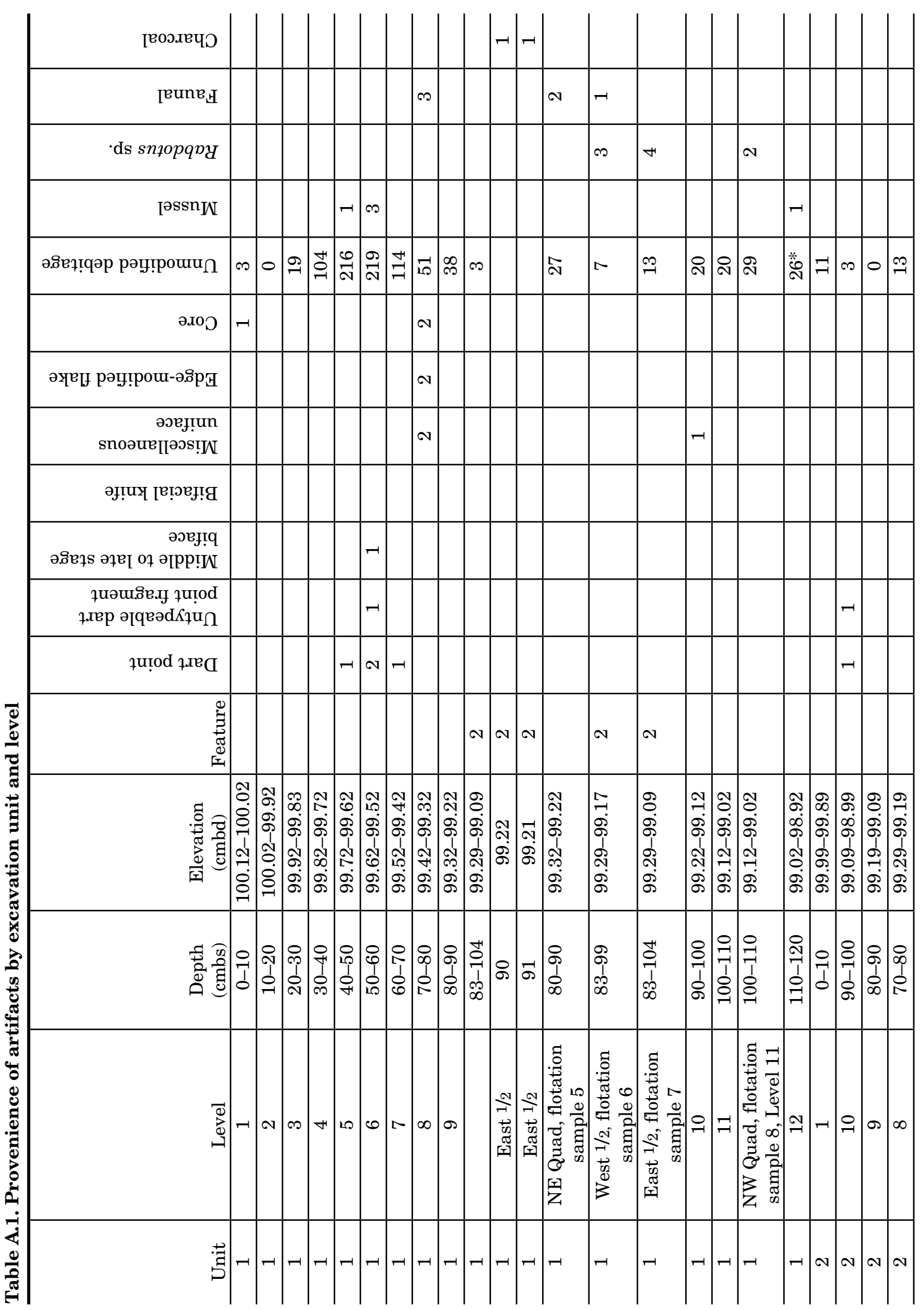


National Register Testing at 41CV1636

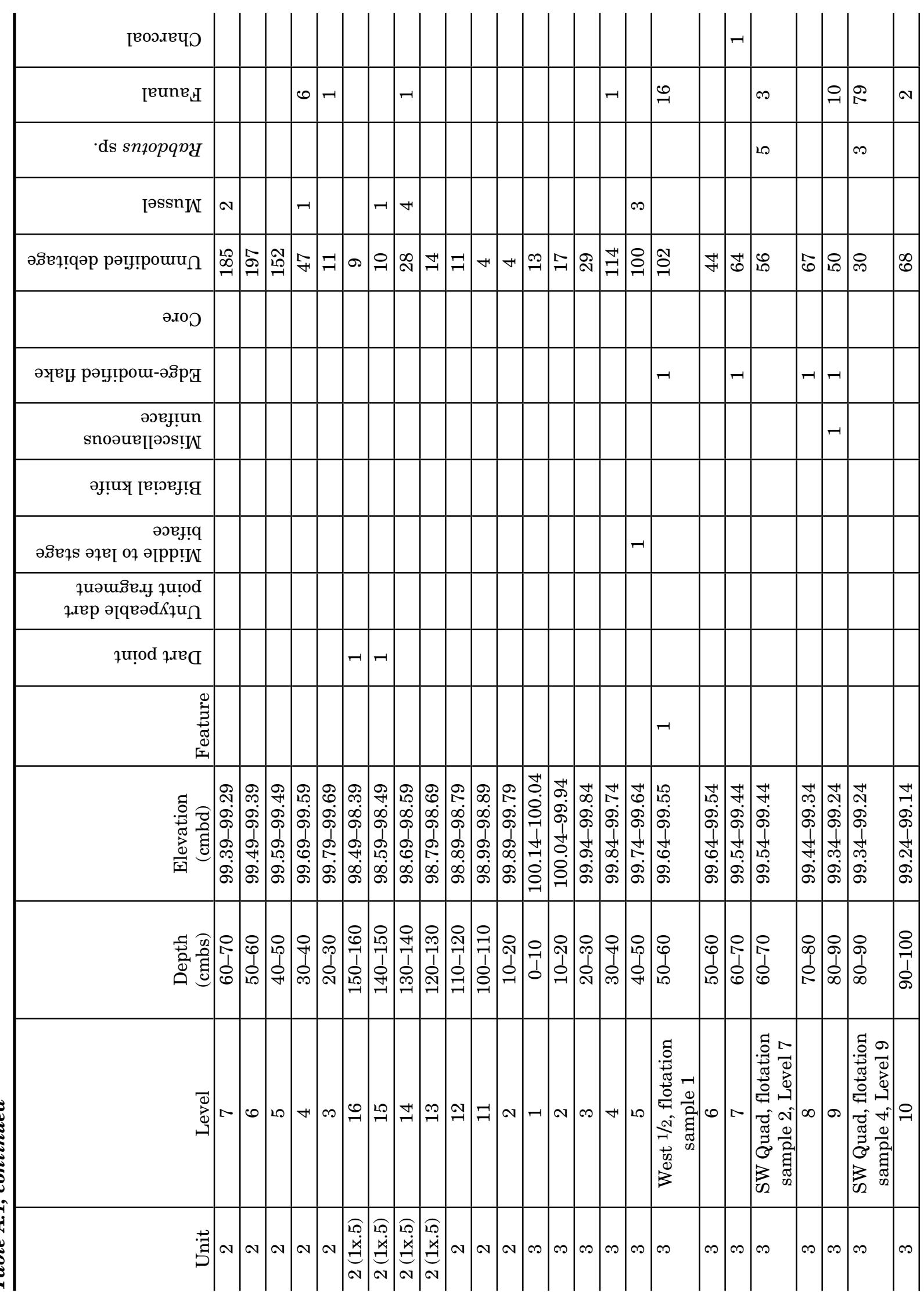




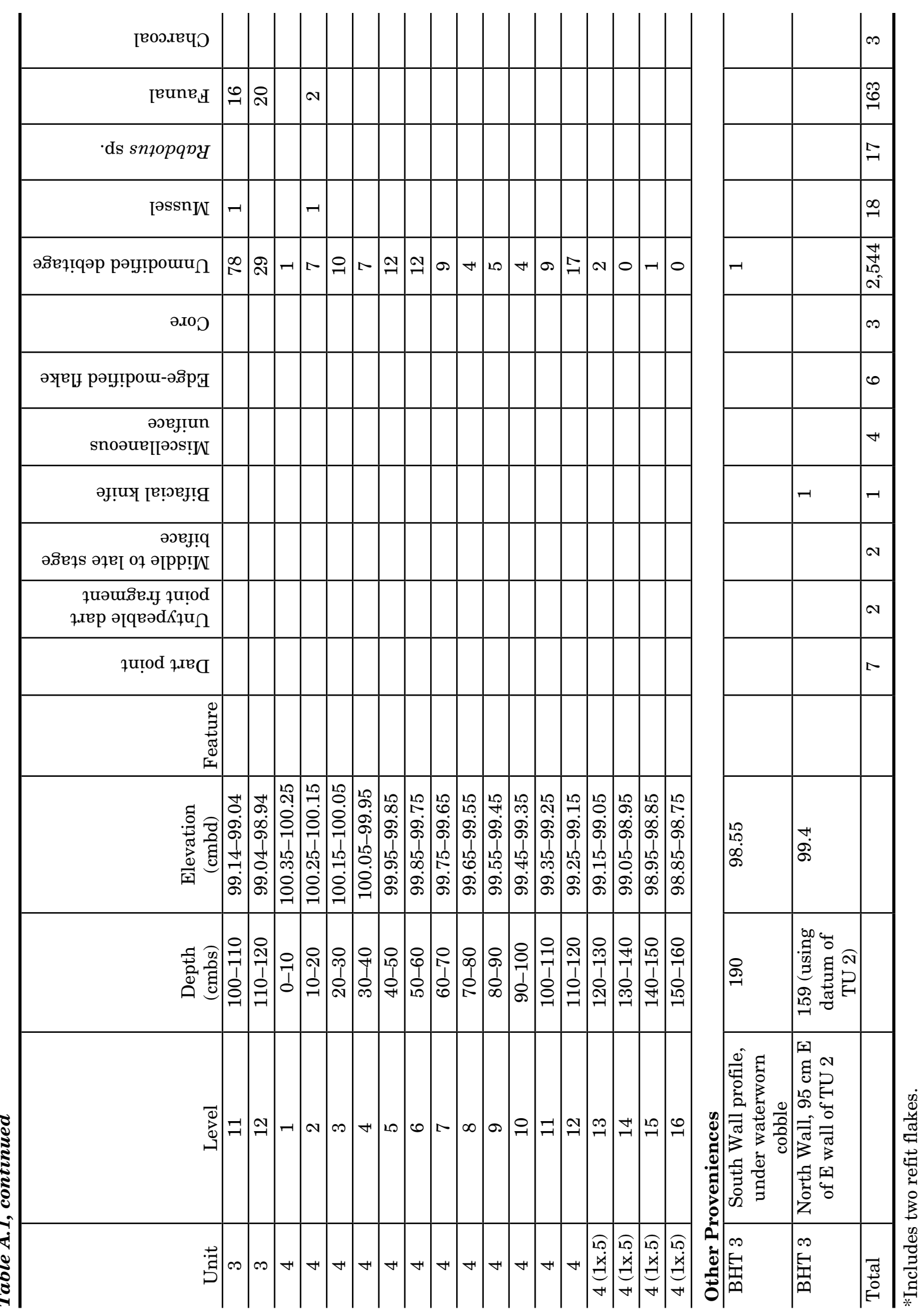




